Marina Marçola Pereira de Freitas

\title{
Efeito da melatonina endógena sobre a reatividade de células endoteliais ex vivo
}

\author{
Endogenous melatonin effect on ex vivo \\ endothelial cells reactivity
}

São Paulo 


\section{Marina Marçola Pereira de Freitas}

\section{Efeito da melatonina endógena sobre a reatividade de células endoteliais ex vivo}

\section{Endogenous melatonin effect on ex vivo endothelial cells reactivity}

Dissertação apresentada ao Instituto de Biociências da Universidade de São Paulo, para obtenção de Título de Mestre em Ciências, na Área Fisiologia Geral.

Orientadora: Regina Pekelmann Markus

São Paulo 


\section{Ficha Catalográfica}

Marçola, Marina

Efeito da melatonina endógena sobre a reatividade de células endoteliais ex vivo.

$144 \mathrm{p}$.

Dissertação (Mestrado) - Instituto de Biociências da Universidade de São Paulo. Departamento de Fisiologia. 2011.

1. Célula endotelial. 2. Melatonina. 3. Memória celular. I. Markus, Regina Pekelmann. II. Universidade de São Paulo. Instituto de Biociências. Departamento de Fisiologia.

Comissão Julgadora

$\operatorname{Prof(a).~Dr(a).~}$

Prof(a). Dr(a).

Prof(a). $\operatorname{Dr}(a)$.

Orientador(a) 
Ao meu avô, Geraldo Marçola, sempre presente pelo que deixou em mim. 
Mostra-se tão graciosa a quem a mira,/ Que nos filtra através do olhar no seio,/ Um dulçor que só entende quem o prova.

Dante Alighieri

Tá cansada, senta/ Se acredita, tenta/ Se tá frio, esquenta/ Se tá fora, entra/ Se pediu, agüenta/ Se sujou, cai fora/ Se dá pé, namora/ Tá doendo, chora/ Tá caindo, escora/ Não tá bom, melhora/ Se aperta, grite/ Se tá chato, agite/ Se não tem, credite/ Se foi falta, apite/ Se não é, imitel Se é do mato, amansel Trabalhou, descanse/ Se tem festa, dance/ Se tá longe, alcance/ Use sua chance/ Se tá puto, quebre/ Tá feliz, requebre/ Se venceu, celebre/ Se tá velho, alquebre/ Corra atrás da lebre/ Se perdeu, procure/ Se é seu, segure/ Se tá mal, se cure/ Se é verdade, jure/ Quer saber, apure/ Se sobrou, congele/ Se não vai, cancele/ Se é inocente, apele/ Escravo, se rebele/ Nunca se atropele/ Se escreveu, remeta/ Engrossou, se meta/ E quer dever, prometal Prá moldar, derreta/ Não se submeta...

Lenine e Ivan Santos 


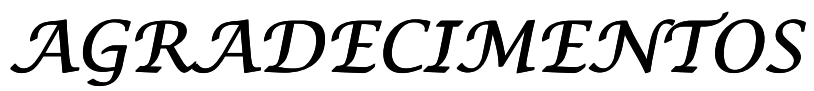

Obrigada Deus, por mais essa caminhada.

Agradeço à minha querida mãe Maria Alzira, pelos ensinamentos e exemplos, por acreditar e se fazer presente mesmo à distância.

À minha irmã, Eloisa, pelo carinho mais sincero e eterno, "na finitude dos nossos laços...o infinito voa!", sempre!

Ao João Roberto pelos cuidados de pai.

Ao Juliano, pelo companheirismo, compreensão, apoio e amor. Obrigada por sempre estar ao meu lado.

À minha avó Izelda, exemplo de vida.

À minha família, tios e primos, nas pessoas do Tio Zé, Tia Nice e Tio Evaldo, pelos momentos de fraternidade. Em especial, à tia Gilza, Tio Durval, Carol e Juliana, por terem aberto as portas e me acolhido!

À família do Juliano pelo carinho.

Aos amigos, Stéphanni Gomide e Lucas Algodoal, pela fidelidade.

Aos amigos da 62BioUFU, pela torcida!

Aos amigos do Laboratório de Cronofarmacologia: Ariana Freitas, Cláudia Emanuele Carvalho Sousa, Daiane Gil Franco, Danilo Mori, Eliana Pereira, Kelly Lima, Leila Lima, Marco Antônio Lapa, Sanseray da Silveira Cruz Machado. Obrigada pelas colaborações, por tornarem o dia-a-dia mais alegre e descontraído. Em especial, às amigas Camila Petrilli e Erika Cecon, pela convivência, confiança e auxílio na correção dessa dissertação.

Aos queridos amigos Eduardo Tamura e Pedro Fernandes por todos os ensinamentos. Obrigada por poder compartilhar esse trabalho com vocês, suas colaborações foram fundamentais. Agradeço também pelas correções desse trabalho. 
À Luciana Pinato e Leila Campos, por se mostrarem sempre prestativas quando precisei.

Aos técnicos, Alex Monteiro, Débora Moura, Eduardo Braga Fernandes e Sandra Muxel, pelo apoio nos mínimos e imprescindíveis detalhes.

À Prof ${ }^{a}$. Zulma Ferreira pelas contribuições e por estar sempre disposta a ajudar.

À Prof ${ }^{a}$. Regina Pekelmann Markus, por me acolher tão prontamente. Obrigada pela oportunidade, por compartilhar suas experiências e pela confiança. Seus ensinamentos sempre me acompanharão.

Por fim, às agências de fomento, FAPESP (2009/04000-0), CNPq e CAPES, pelo apoio financeiro. 


\section{Sumário}

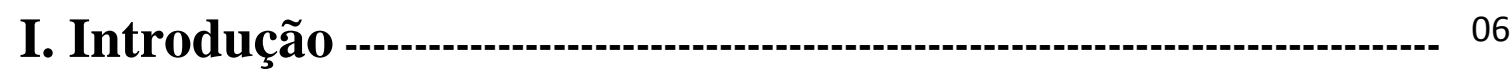

1 Células Endoteliais - --o-n 07

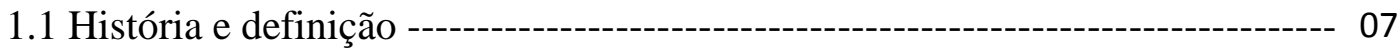

1.2 Estrutura das células endoteliais --- 09

1.3 Controle da homeostase vascular ---o- 11

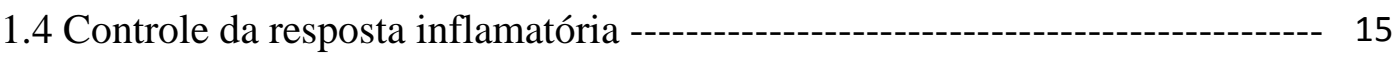

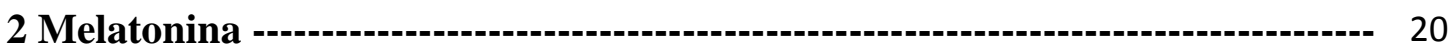

2.1 Efeito protetor versus cronobiótico da melatonina ------------------------ 20

2.2 Via biossintética, controle circadiano da produção e via de degradação da

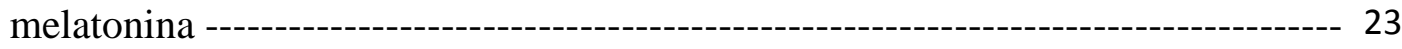

2.3 Mecanismos de ação da melatonina -- 25

2.4 Eixo imune-pineal: uma comunicação bidirecional entre a glândula pineal e o sistema imunológico -- 26

2.5 Endotélio como alvo privilegiado do eixo imune-pineal -------------------- 32

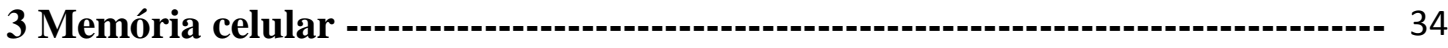

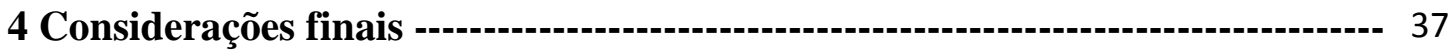

II. Objetivos --- 39

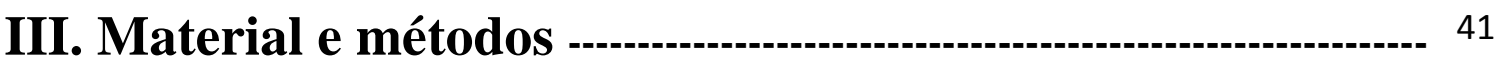

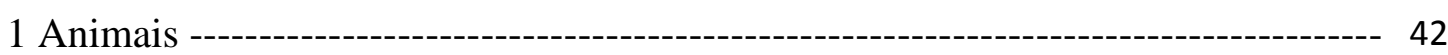

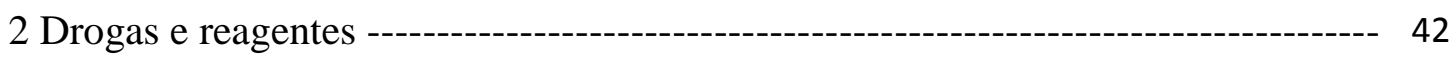

3 Preparo de drogas ---

4 Protocolo experimental -----------

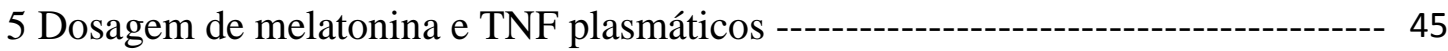

6 Extração do RNA total ---o---on

7 RT-PCR --- 47

8 Determinação da transcrição do gene Aanat por RT-PCR em tempo real ---------- 47

9 Cultura de células endoteliais ---o---o- 48

10 Ensaio de imunocitoquímica por microscopia confocal ------------------------ 49

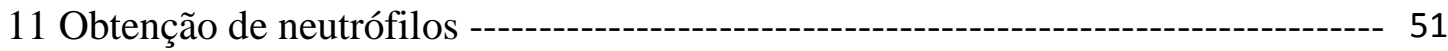

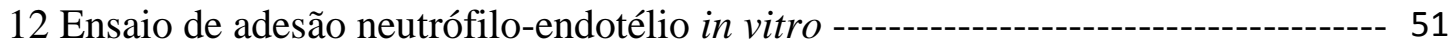




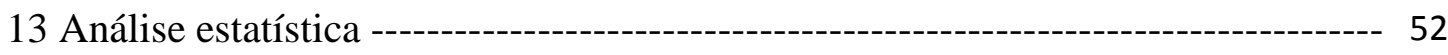

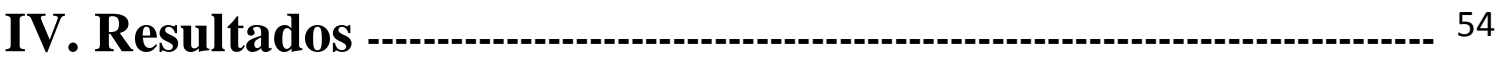

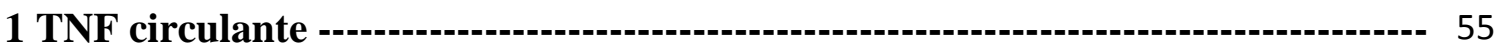

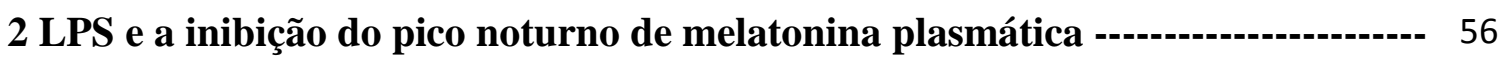

2.1 Efeito do LPS na inibição da melatonina produzida pela glândula pineal -------- 57

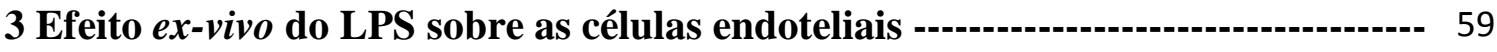

3.1 Ativação da células endoteliais após injeção de LPS ---------- 60

3.2 Ensaio de adesão de neutrófilos in vitro ---

4 Efeito da hora do dia na reatividade de células endoteliais em cultura ---------- 63

4.1 Estado de ativação das células endoteliais dependente da hora de obtenção ----- 64

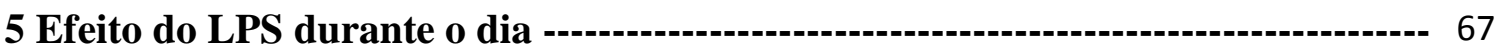

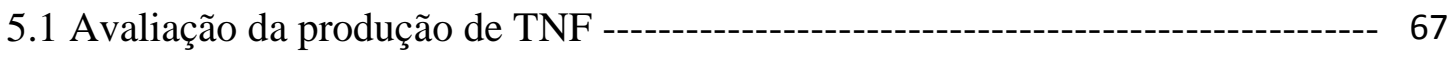

5.2 Efeito ex vivo do LPS sobre as células endoteliais obtidas de animais mortos

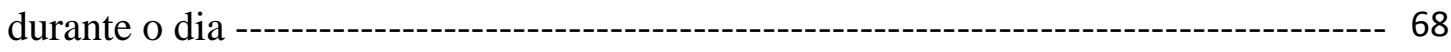

6 Células endoteliais são primadas pela concentração plasmática de melatonina - 72

V. Discussão

VI. Conclusões -...- 89

VII. Resumo -..-

VIII. Abstract -.- 96

IX. Referências Bibliográficas -..- 98

X. Súmula Curricular 


\section{Lista de Abreviatura}

5-HTP 5-hidroxitriptofano

AA ácido araquidônico

AA-NAT arilalquilamina $\mathrm{N}$-acetiltransferase

AC adenilil ciclase

AFMK $\quad \mathrm{N}^{1}$-acetil- $\mathrm{N}^{2}$-formil-5-metoxikynuramina

AMK N-acetil-5-metoxikynunamina

AMPc monofosfato de adenosina cíclico

AP-1 proteína ativadora 1

ATP adenosina trifostato

BCG bacilo Calmette-Guerin

CaM calmodulina

cDNA DNA complementar

COX-1/2 ciclooxigenase -1 e 2

Ct threshold cycle

DMEM meio essencial de Dulbecco, modificado

DNA ácido desoxirribonucléico

EDRF endothelium-derived relaxing factor

EDTA ácido etilenodiaminotetraacético

ELISA enzyme-linked immunosorbent assay

eNOS sintase de óxido nítrico endotelial

EPM erro padrão da média

$\mathbf{E T}_{\mathrm{A} / \mathbf{B}} \quad$ receptor de endotelina A e B

FITC isotiocianato de fluoresceína

GABA ácido gama-aminobutírico

GC guanilil ciclase

GMPc monofosfato de guanosina cíclico

GTP guanosina trifosfato

$\mathbf{H}_{2} \mathbf{O}_{2}$ peróxido de hidrogênio 


\begin{tabular}{|c|c|}
\hline HBSS & solução salina de Hanks balanceada \\
\hline HIF & fator de indução de hipóxia \\
\hline HIOMT & hidroxi-indol-O-metiltransferase \\
\hline HUVECs & células endoteliais do cordão umbilical humano \\
\hline ICAM-1 & intercellular adhesion molecule 1 \\
\hline IFN- $\gamma$ & interferon gama \\
\hline Ig & imunoglobulina \\
\hline IKB & proteína inibitória kappa $\mathrm{b}$ \\
\hline IKK & proteína quinase de IKB \\
\hline IL & interleucina \\
\hline iNOS & sintase de óxido nítrico induzida \\
\hline $\mathbf{I P}_{3}$ & inositol trifosfato \\
\hline JAM & junctional adhesion molecule \\
\hline L-Arg & L-arginina \\
\hline LPS & lipopolissacarídeo \\
\hline MAPK & mitogen-activated protein kinase \\
\hline $\mathbf{m M}$ & milimolar \\
\hline $\mathbf{M T}_{1 / 2 / 3}$ & receptor de melatonina do subtipo 1,2 e 3 \\
\hline Myd88 & myeloid differentiation primary response gene 88 \\
\hline NAS & $\mathrm{N}$-acetilserotonina \\
\hline NFKB & fator nuclear kappa $\mathrm{B}$ \\
\hline nm & nanometros \\
\hline $\mathbf{n M}$ & nanomolar \\
\hline nNOS & sintase de óxido nitric neural \\
\hline NO & óxido nítrico \\
\hline NOS & sintase de óxido nítrico \\
\hline NSQ & núcleos supraquiasmáticos \\
\hline PBS & tampão fosfato \\
\hline PCR & reação em cadeia da polimerase \\
\hline $\mathbf{P E}$ & ficoeritrina \\
\hline PECAM-1 & platelet-endothelial cellular adhesion molecule \\
\hline $\mathbf{P G I}_{2}$ & prostaciclina \\
\hline PLA & fosfolipase $\mathrm{A}_{2}$ \\
\hline
\end{tabular}




\begin{tabular}{ll} 
PM & picomolar \\
PMN & células polimorfonucleares \\
PVN & núcleo paraventricular \\
RNA & ácido ribonucléico \\
RNS & espécies reativas de nitrogênio \\
ROR & receptor órfão retinóide \\
ROS & espécies reativas de oxigênio \\
RT-PCR & reverse transcriptase-PCR \\
RZR & receptor Z retinóide \\
TLR4 & receptor do tipo toll 4 \\
Tm & melting temperature \\
TMB & tetrametilbenzidina \\
TNF & fator de necrose tumoral \\
TNFR1 & receptor tipo 1 de fator de necrose tumoral \\
TPH1 & triptofano hidroxilase 1 \\
TRITC & tetrametil rodamina isotiocianato \\
VCAM-1 & vascular cellular adhesion molecule \\
VEGF & fator de crescimento endotelial vascular \\
vWF & fator de von Willebrand \\
ZT & zeitgeber time \\
$\boldsymbol{\mu} M$ & micromolar \\
\hline
\end{tabular}




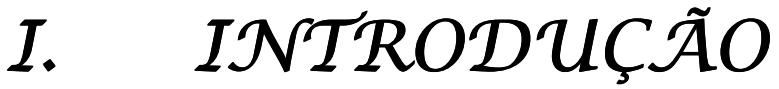

\section{CÉLULAS ENDOTELIAIS}

\subsection{História e definição}

Já em 1865, Wilhelm His conceitua o endotélio com o intuito de diferenciar o revestimento das cavidades internas com o revestimento externo, o epitélio. Assim, originalmente, o endotélio seria a camada de revestimento dos vasos sanguíneos, linfáticos e das cavidades recobertas pelo mesotélio. Somente em 1901, Wilhelm von Waldeyer-Hartz descreveu o endotélio como a camada de revestimento interno dos vasos sanguíneos e linfáticos (para revisão, Aird, 2007).

Desde a década de 1940, acreditava-se na existência de uma barreira entre a porção interna dos capilares e o tecido adjacente, no entanto, nesta época diversos trabalhos propunham uma barreira não celular formada apenas por proteínas plasmáticas (Danielli, 1940; Chambers \& Zweifach, 1947). Em um estudo de permeabilidade vascular em sapos, Danielli sugeriu que esta interface fosse controlada por poros protéicos permeáveis (Danielli, 1940). Em 1966, Luft por meio de observações em microscopia eletrônica utilizando técnicas de coloração de vermelho de rutênio, demonstrou a existência de uma camada endocapilar de origem não conhecida (Luft, 1966). Hoje já se sabe que essa camada é constituída por proteoglicanas e glicoproteínas, as quais formam o glicocálix presente na superfície de todos os tipos celulares. Já em 1974, Copley sugeriu a presença de uma camada endoendotelial parcialmente imóvel formada por fibrina. Para ele esta camada protegeria a rede 
vascular das mudanças de fluxo sanguíneo, uma vez que a presença de uma simples camada plasmática, como havia sugerido os pesquisadores anteriores, não seria capaz de suportar o fluxo sanguíneo (Copley, 1974). Ainda nesta época, pesquisadores começaram a isolar e caracterizar células endoteliais de cordão umbilical (Gimbrone et al., 1974). No entanto, durante muito tempo, as técnicas de coloração impossibilitaram uma real avaliação da camada endotelial já que diversos corantes degradavam moléculas do endotélio ou ainda não possuíam um amplo espectro de marcação. Hoje, a camada endotelial é muito bem descrita e caracterizada, no entanto, o entendimento da biologia das células endoteliais ainda não é completo.

O endotélio é a monocamada celular que recobre internamente os vasos sanguíneos e linfáticos. Sua organização é dependente de um conjunto de moléculas que garantem sua conectividade e integridade como um todo. Sendo assim, as células endoteliais se interligam por junções e estruturas adesivas que, juntamente com moléculas do glicocálix e do citoesqueleto, formam uma rede celular capaz de regular a permeabilidade vascular (para revisão, Pries et al., 2000). Além disso, as células endoteliais possuem uma maquinaria que permite a endocitose de substâncias extracelulares e o transporte intracelular (para revisão, Aird, 2007). Estruturalmente as células endoteliais se encontram em um formato achatado, podendo em alguns casos apresentar-se na forma cubóide ou arredondadas dependendo do local onde são encontradas. Normalmente, o núcleo celular se alinha de acordo com a hemodinâmica do fluxo sanguíneo (para revisão, Pries et al., 2000).

As células endoteliais originam-se do mesoderma. Durante a embriogênese, células precursoras mesenquimais formam as chamadas ilhas sanguíneas, nas quais as células mais externas formam a camada endotelial e as mais internas as células hematopoiéticas. Posteriormente, ocorre a fusão destas ilhas formando, então, toda a 
rede vascular. As artérias são vasos formados pela camada endotelial envolta por multicamadas de células musculares lisas e fibras elásticas. Já as veias são constituídas por uma fina camada muscular e poucas fibras elásticas recobrindo a camada endotelial. Os capilares possuem apenas a monocamada endotelial juntamente com alguns pericitos, células mesenquimais que ajudam no suporte dos vasos e na regulação do fluxo sanguíneo. Anteriormente, acreditava-se que a diferenciação das células endoteliais em artérias, veias e capilares era dependente do local em que se encontravam e da diferença do fluxo sanguíneo. Hoje, trabalhos demonstram uma série de mecanismos moleculares transcricionais que induzem a diferenciação e desenvolvimento destas células nos processos de angiogênese e vasculogênese (para revisão, de Val \& Black, 2009; Bras et al., 2010).

\subsection{Estrutura das células endoteliais}

Após a diferenciação e formação do vaso, as células endoteliais se organizam uma adjacente a outra formando uma monocamada celular que regula a permeabilidade vascular. Para isso, essas células possuem moléculas especializadas em selar uma célula à outra garantindo a integridade do endotélio. A aderência intercelular é formada por um conjunto de moléculas que têm organização diferente entres os tipos de vasos. Em artérias de grande calibre, as células endoteliais estão mais fortemente interligadas, garantindo a função de condução sanguínea, além de ser um mecanismo de proteção contra as forças do fluxo sanguíneo. Nas arteríolas, as junções são mais compactas quando comparadas aos capilares. Já nas vênulas essa propriedade é quase perdida (para revisão, Aird, 2007).

Dois tipos de junções celulares são encontrados nas células endoteliais, as junções compactas (ou zona ocludente) e as junções aderentes (ou zona aderente). As 
junções compactas estão presentes em toda membrana celular da porção lateral das células. A ocludina é a principal proteína das junções compactas encontrada no endotélio. Outras moléculas, como claudina-5 e proteínas da família JAM (do inglês, “junctional adhesion molecules”) também constituem a zona ocludente. Já as junções aderentes são formadas por caderinas, cuja porção citoplasmática liga-se a proteínas do citoesqueleto, como as cateninas. Essas junções celulares e estruturas adesivas estão associadas à regulação da permeabilidade vascular de células e componentes circulantes (para revisão, Bogatcheva \& Verin, 2008; Wittchen, 2009).

Outras moléculas pertencentes à família das imunoglobulinas (Ig) também participam da formação da camada endotelial, garantindo a junção de uma célula à outra. Dentre elas, a PECAM-1 (do inglês "platelet-endothelial cellular adhesion molecule," CD-31) está associada tanto a função adesiva quanto à participação em outros processos, como a migração de leucócitos que será abordada adiante. A PECAM1 é uma glicoproteína transmembrânica também expressa em plaquetas, neutrófilos, monócitos, e alguns subtipos de linfócitos. É considerada como marcador fenotípico de células endoteliais, onde são expressas constitutivamente. A fim de garantir a adesão de células endoteliais, PECAM-1 também se liga às estruturas citoplasmáticas do citoesqueleto como as cateninas, além de interagir com outras moléculas PECAM-1 de células adjacentes (para revisão, Wittchen, 2009; Privratsky et al., 2010).

Além de toda esta estrutura que garante a justaposição das células endoteliais, a camada endotelial é recoberta por diversas moléculas extracelulares como, proteínas, glicoproteínas, proteoglicanas e glicolipídeos. Essas moléculas se associam à porção extracelular das moléculas aderentes e compactas, além de integrinas e selectinas presentes na membrana celular formando o glicocálix, o qual interage com os 
componentes plasmáticos em um equilíbrio dinâmico dependente do fluxo sanguíneo (para revisão, Pries et al., 2000).

Assim, considerando todas estas propriedades estruturais acima descritas, a camada endotelial pode ser contínua ou descontínua. Quando contínua, as células endoteliais se encontram mais justapostas umas às outras, podendo ser fenestradas ou não fenestradas. No cérebro, pele, coração e pulmão o grau de justaposição das células é maior do que em tecidos com propriedades de filtração ou com maior permeabilidade como o intestino, glândulas, plexos coróide e glomérulos renais. A camada endotelial descontínua é encontrada em algumas regiões do fígado e caracteriza-se pela presença de poros entre uma célula e outra (para revisão, Aird, 2007). Dessa forma, a permeabilidade da camada endotelial depende da quantidade de junções e estruturas adesivas e da presença ou não de fenestras.

Resumidamente, a estrutura morfológica da camada endotelial varia com a localização anatômica em que se encontra, podendo ser revestida de um glicocálix mais espesso em determinadas regiões ou possuir junções celulares que modulam a passagem de células e substâncias de acordo com o seu tamanho.

\subsection{Controle da homeostase vascular}

Quanto à função das células endoteliais, elas estão associadas à regulação da homeostase vascular e à montagem da resposta inflamatória. As células endoteliais podem ser encontradas em estado quiescente ou ativadas, dependendo da estimulação por fatores endógenos, como produtos do plasma ou liberados por células, ou por fatores exógenos, como componentes microbianos ou fármacos (para revisão, Pober \& Sessa, 2007). 
As células endoteliais regulam a fluidez sanguínea uma vez que são responsáveis pela modulação da coagulação sanguínea e do tônus vascular (figura 1). Em estado de repouso, a camada endotelial tem propriedade anticoagulante e antitrombótica. Os principais moduladores anticoagulantes produzidos pelas células endoteliais são a prostaciclina $\left(\mathrm{PGI}_{2}\right)$ e o óxido nítrico $(\mathrm{NO})$, que atuam sobre o monofosfato de adenosina cíclico (AMPc) das plaquetas, impedindo sua agregação (figura 1). Esses mediadores são produzidos constitutivamente, mas suas produções podem ser aumentadas por agonistas endógenos como bradicinina, trombina e adenosina trifosfato (ATP). Além disso, as células endoteliais, quando quiescentes, modulam vias anticoagulantes como a via da proteína C/proteína S, inibindo a formação de trombos. No entanto, quando estimuladas por citocinas, as células endoteliais inibem a via anticoagulante e passam a produzir mediadores pró-coagulantes e trombóticos. Dentre estes, o fator ativador de plaquetas, que propicia a agregação plaquetária e adesão destas com as células endoteliais, e o fator de von Willebrand (vWF), constitutivamente expresso e estocado em vesículas intracelulares que são liberadas quando estimuladas por trombina (para revisão, Michiels, 2003).

No início da década de 1980, verificou-se que a vasodilatação induzida por acetilcolina era dependente da integridade da camada endotelial e de um fator de relaxamento derivado do endotélio, denominado de EDRF (do inglês, "endotheliumderived relaxing factor"; Furchgott \& Zawadzki, 1980). Poucos anos depois, verificouse que este fator era uma molécula gasosa, o óxido nítrico (NO; Palmer et al., 1987). O NO é sintetizado a partir do aminoácido L-arginina (L-Arg) por meio da enzima sintase de óxido nítrico (NOS). Existem três isoformas desta enzima, cuja nomenclatura remete ao primeiro local no qual foram descritas: NOS neuronal (nNOS), NOS endotelial (eNOS), e NOS induzida (iNOS). As duas primeiras são expressas constitutivamente 
nos mais diversos tipos celulares, e sua ativação se faz, sobretudo pelo aumento de cálcio intracelular, culminando na formação do complexo cálcio-calmodulina $\left(\mathrm{Ca}^{2+}\right.$ CaM). Por outro lado, a iNOS é expressa em maior quantidade frente a um estímulo inflamatório e está comumente relacionada à resposta inflamatória (Moncada et al., 1997). Nas células endoteliais se encontram as isoformas eNOS e iNOS (para revisão, Villanueva \& Giulivi, 2010).

A partir de então, diversos trabalhos demonstram como o NO controla o relaxamento dos vasos sanguíneos e como este mediador pode ser utilizado a favor do controle de doenças cardiovasculares. O NO produzido pelas células endoteliais atua sobre as células musculares lisas, presentes no tecido adjacente à camada endotelial e, também, constituintes dos vasos sanguíneos (figura, 1; Moncada et al., 1988). O NO diminui a concentração intracelular de cálcio na musculatura lisa, ativando a guanilil ciclase (GC) que converte guanosina trifosfato (GTP) em monofosfato de guanosina cíclico (GMPc), promovendo o vasorelaxamento (Denninger \& Marletta, 1999). A enzima eNOS é constitutivamente expressa, no entanto sua expressão é regulada por diversos agonistas como acetilcolina, angiotensina II, bradicinina, histamina, entre outros (Michel et al., 1997; Ju et al., 1998). A regulação do tônus vascular não é feita somente pelo $\mathrm{NO}$, a $\mathrm{PGI}_{2}$, além de regular a coagulação sanguínea, também atua nas células da musculatura lisa promovendo o vasorelaxamento devido ao aumento de AMPc pela adenilil ciclase (AC; figura 1; para revisão, Michiels, 2003). 


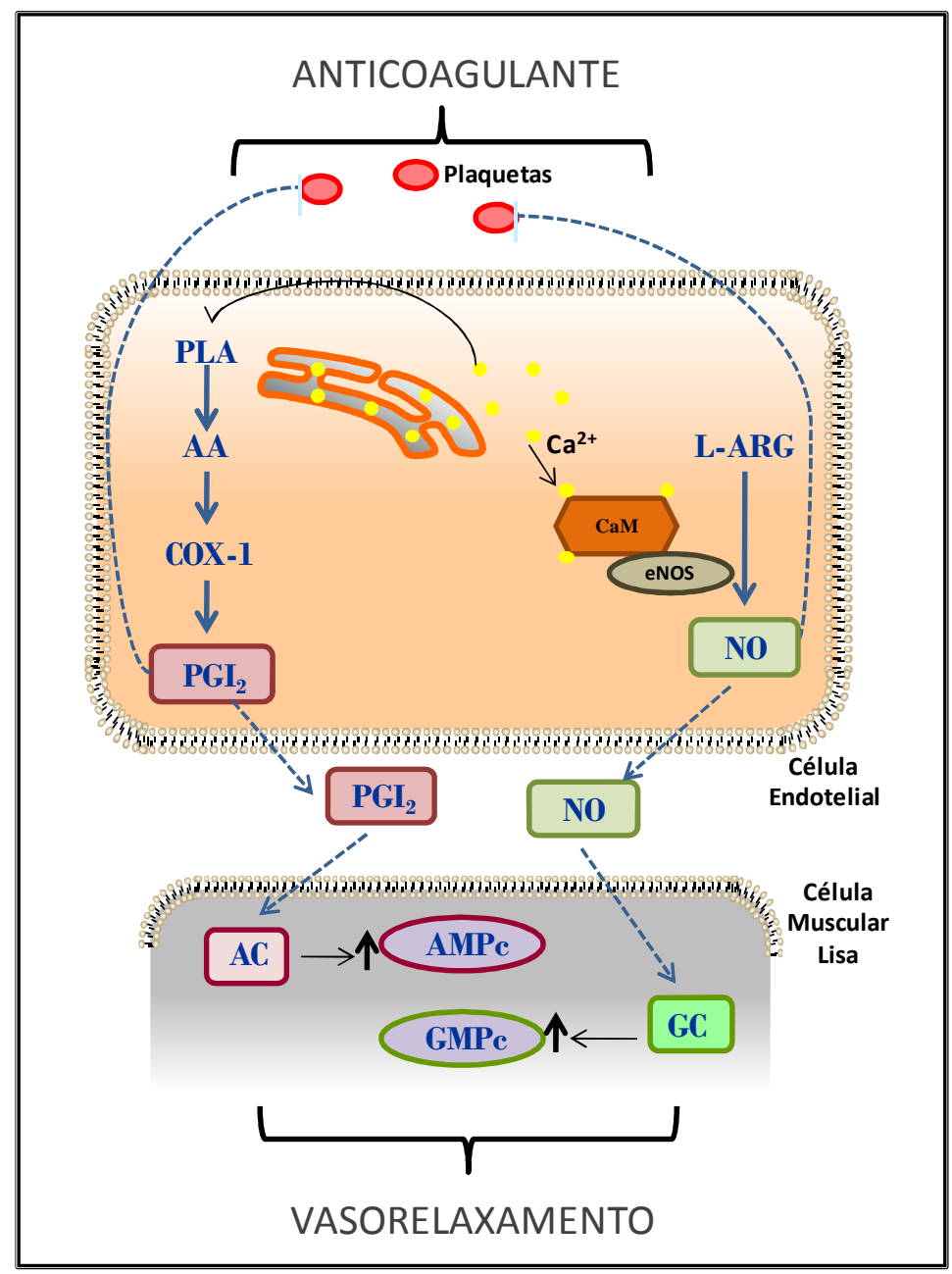

Figura 1 - Controle do tônus vascular e da coagulação sanguínea por células endoteliais. $O$ endotélio, em estado de quiescência, expressa constitutivamente fatores com propriedades anticoagulante e vasorelaxante. Dentre estes, os mais diretamente associados com essas funções são a prostaciclina $\left(\mathrm{PGI}_{2}\right)$ e o óxido nítrico (NO). Mediadores endógenos como bradicinina, acetilcolina, ATP, histamina, dentre outros potenciam a síntese desses fatores, por induzirem o aumento intracelular de cálcio $\left(\mathrm{CA}^{2+}\right)$. A $\mathrm{PGI}_{2}$ é derivada da fosforilação de endoperoxidases pela enzima ciclooxigenase-1 (COX-1) produzida a partir do ácido araquidônico (AA) liberado pela fosfolipase $\mathrm{A}_{2}$ (PLA). Já o NO é sintetizado a partir da Larginina (L-ARG) pela enzima sintase de óxido nítrico endotelial (eNOS). Esta enzima, por sua vez, é ativada pelo complexo $\mathrm{Ca}^{2+}$-calmodulina $(\mathrm{CaM}) . \mathrm{A} \mathrm{PGI}_{2}$ e o $\mathrm{NO}$ atuam sobre a célula muscular lisa ativando a adenilil (AC) e guanilil (AG) ciclase, aumentando os níveis de adenosina $(\mathrm{AMPc})$ e guanosina $(\mathrm{GMPc})$ monofosfato cíclico, respectivamente, culminando no relaxamento do vaso sanguíneo. Além disso, esses fatores inibem a agregação de plaquetas, impedindo a formação de coágulos. 
Por outro lado, em condições fisiopatológicas, como hipóxia, as células endoteliais produzem mediadores que agem como vasoconstritores. O principal componente deste mecanismo são proteínas da família das endotelinas. As células endoteliais produzem pró-endotelina que é ativada extracelularmente por enzimas conversoras de endotelina presentes na porção extracelular da membrana de células endoteliais (Turner et al., 1998). A endotelina atua sobre as células da musculatura lisa via ativação do receptor de endotelina $\left(\mathrm{ET}_{\mathrm{A}}\right)$ aumentando os níveis de cálcio $\left(\mathrm{Ca}^{2+}\right)$ intracelular pela via do inositol trifosfato $\left(\mathrm{IP}_{3}\right)$, promovendo a contração vascular (Kedzierski \& Yanagisawa, 2001). Interessantemente, a endotelina também atua sobre receptores do endotélio $\left(\mathrm{ET}_{\mathrm{B}}\right)$ promovendo a produção de $\mathrm{NO}$ e $\mathrm{PGI}_{2}$, os quais possuem efeito contrário à contração vascular, explicando o vasorelaxamento observado após a vasoconstrição (para revisão, Michiels, 2003).

\subsection{Controle da resposta inflamatória}

As células endoteliais são a porta de entrada de uma resposta inflamatória, visto que constituem a interface entre a corrente sanguínea e o tecido inflamado. A resposta inflamatória aguda é montada frente a um estímulo injuriante e se constitui de uma série de processos a fim de solucionar os problemas por ele causados. As células endoteliais participam da formação de três dos cinco pontos cardeais da inflamação. Os primeiros eventos envolvidos na montagem da resposta baseiam-se em uma rápida contração seguida da dilatação dos vasos, aumentando o fluxo sanguíneo para o tecido lesionado (rubor e calor). Posteriormente, ocorre o aumento da exsudação de fluidos culminando na migração de células imunocompetentes para o local inflamado (tumor). A dor é causada por mediadores produzidos por leucócitos ativados e a perda de função está associada ao conjunto dos demais eventos (para revisão, Pober \& Sessa, 2007). Assim, 
as células endoteliais e os leucócitos são os principais constituintes da montagem desse processo fisiopatológico e diversos mediadores orquestram o sequenciamento de eventos que caracterizam a resposta inflamatória.

As células endoteliais estão equipadas para o reconhecimento de componentes de microorganismos, entre estes, componentes bacterianos, como o lipopolissacarídeo (LPS) encontrado na parede celular de bactérias gram-negativas. O LPS ativa células endoteliais por ligação com receptores "toll" subtipo 4 (TLR4, do inglês "toll like receptor") e desencadeia uma cascata de sinalização dependente da proteína adaptadora Myd88, a qual culmina com a translocação do fator de transcrição nuclear "kappa" B (NFKB) para o núcleo e com a ativação da via das proteínas MAP quinases (MAPK, para revisão, Dauphinee \& Karsan, 2006). Além da ativação por LPS, citocinas e mediadores inflamatórios produzidos durante a resposta inflamatória também promovem ativação do endotélio, sobretudo induzindo a adesão de leucócitos (para revisão, Liu \& Kubes, 2003).

Durante a montagem da reposta inflamatória, a migração de leucócitos é o principal mecanismo regulado pelas células endoteliais. Este processo deve ser devidamente controlado, uma vez que a transmigração exacerbada de células imunológicas pode causar complicações como aterosclerose, inflamação crônica, esclerose múltipla, e artrite reumatóide (para revisão, Wittchen, 2009). Basicamente, a migração de leucócitos para o tecido lesionado ocorre, sobretudo, em três etapas: rolamento, adesão e migração propriamente dita. Diversas moléculas expressas pelas células endoteliais e pelos leucócitos regulam cada uma dessas etapas (figura 2).

O rolamento é mediado por selectinas, principalmente a L-selectina, expressas nos leucócitos que se ligam a glicoproteínas das células endoteliais. Neste momento, uma série de sinalizações intracelulares que culminam na síntese de mediadores 
inflamatórios propicia a ativação das células endoteliais, fazendo com que estas expressem outros subtipos de selectinas, como as P-selectina e E-selectina, que iniciam a próxima etapa, a adesão. A firme adesão é mediada pela interação entre as integrinas expressas por leucócitos e as moléculas da família das Ig, como a ICAM-1 (do inglês, “intercellular adhesion molecule 1”). Além da ICAM-1, células endoteliais também expressam outras moléculas, como a VCAM (do inglês, "vascular cellular adhesion molecule"), que são glicoproteínas transmembrânicas ativamente expressas frente a estímulo inflamatório devido à translocação nuclear do NFKB. Por último, a migração propriamente dita é regulada pela interação da PECAM-1 expressa por células endoteliais e leucócitos. Como mencionado anteriormente, a PECAM-1 é expressa principalmente na região de junção intercelular e contribui para a passagem de células imunológicas para o tecido lesionado (figura 2; para revisão, Michiels, 2003; CookMills \& Deem, 2005; Woodfin et al., 2007; Smith, 2008; Lawson \& Wolf, 2009; Rahman \& Fazal, 2009; Zarbock \& Ley, 2009; Privratsky et al., 2010). 


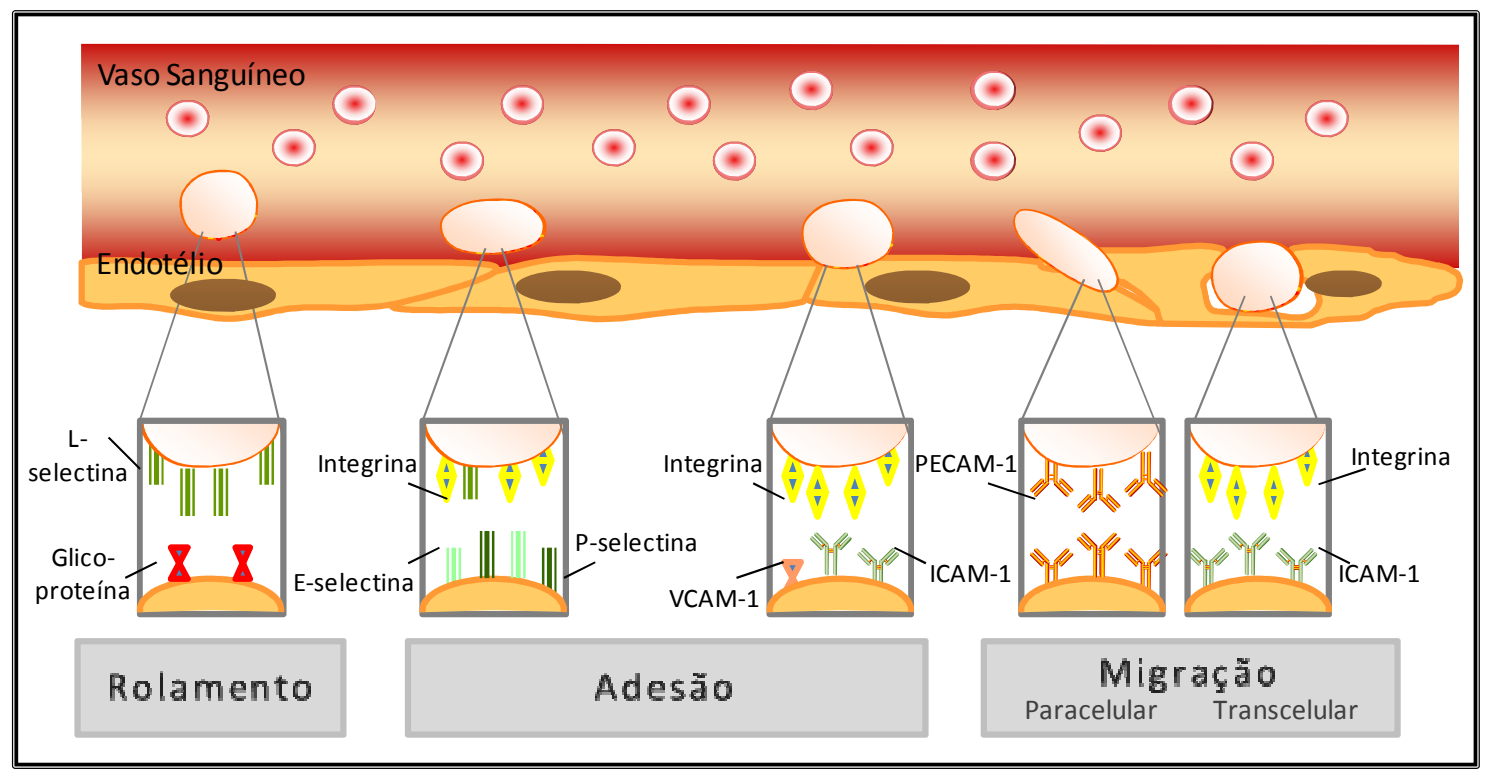

Figura 2 - Papel das células endoteliais na migração de células imunocompetentes. A migração de leucócitos para o tecido lesionado é o principal mecanismo regulado por células endoteliais durante a montagem de uma resposta inflamatória. Esse processo é mediado basicamente por três etapas que resultam na passagem de células imunológicas para o tecido adjacente. Os quadros mostram detalhadamente as interações moleculares entre as células.

A descrição de que leucócitos ativados "deslizam" entre o espaço de junção intercelular até atingirem o tecido lesionado é bem caracterizada na literatura. Este processo é conhecido como migração paracelular. Atualmente, é cada vez mais evidente, que além da migração paracelular, células imunológicas são capazes de migrar através do interior das células endoteliais, por meio de vacúolos citoplasmáticos. Esta via é conhecida como transcelular (figura 2). No entanto, o funcionamento molecular desta última ainda não é bem demonstrado, podendo ser dependente do tipo e do estado de ativação dos leucócitos e das células endoteliais (para revisão, Rahman \& Fazal, 2009).

A produção de NO durante uma resposta inflamatória também é importante no combate ao patógeno, devido à citotoxicidade desta molécula (Moncada et al., 1997). Como mencionado anteriormente, as células endoteliais, quando ativadas, produzem 
grande quantidade de NO a partir da iNOS. Frente a um estímulo inflamatório, a síntese de iNOS é induzida pela translocação nuclear do fator de transcrição NFKB, que promove a síntese de diversos outros mediadores pró-inflamatórios (figura 3; Kawai \& Akira, 2007; Heba et al., 2001).

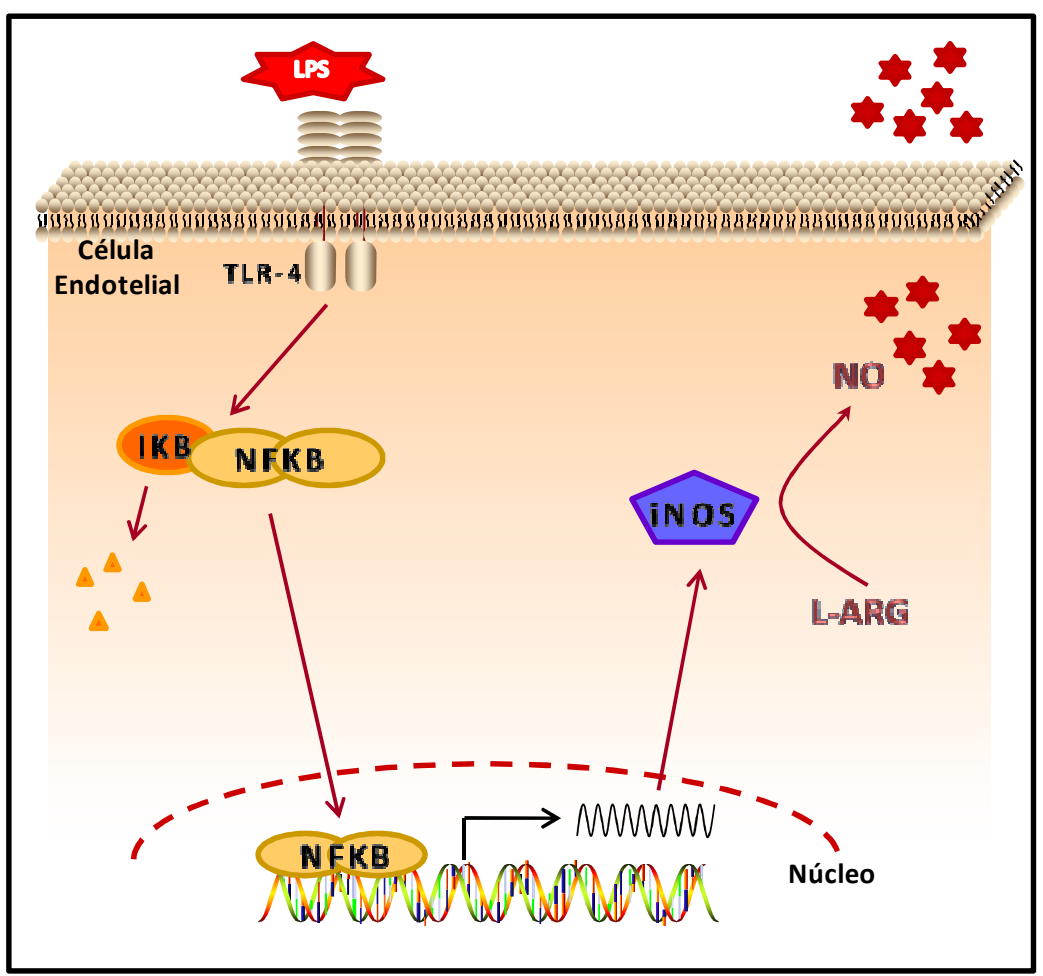

Figura 3 - Produção de NO por células endoteliais durante uma resposta inflamatória. Estímulos inflamatórios, como lipopolissacarídeo (LPS) de bactérias gram-negativas, promovem a transmigração nuclear do fator de transcrição NFKB por induzirem a degradação da proteína inibitória "kappa" B (IKB). Uma vez no núcleo, o NFKB induz a transcrição gênica de diversos mediadores inflamatórios como a sintase de óxido nítrico induzida (iNOS) que aumenta a produção de óxido nítrico (NO) a partir da L-arginina (LARG). 


\section{MELATONINA}

\subsection{Efeito protetor versus efeito cronobiótico da melatonina}

Em 1958, Lerner e colaboradores isolaram uma substância da glândula pineal de bovinos que, em baixas concentrações, é capaz de alterar a cor da pele de anfíbios. Essa substância recebeu o nome de melatonina, devido à sua ação tônica (tonina - tônus) sobre melanóforos dermais (mela - melanóforos; Lerner et al., 1958).

A glândula pineal é a fonte de produção de melatonina mais comumente conhecida. Classicamente, a melatonina é o hormônio do escuro, pois seu pico de produção ocorre durante a fase escura (para revisão, Simmoneaux \& Ribelayga, 2003). No entanto, a síntese de melatonina ocorre de forma não necessariamente rítmica e/ou tônica ao longo do dia em medula óssea (Tan et al., 1999), trato gastrintestinal de ratos (Bubenik et al., 1992), fígado, rim e baço de roedores e primatas (Menendez-Pelaez et al., 1993), placenta humana (Lanoix et al., 2008) e células imunocompetentes, como macrófagos da cavidade peritoneal (Martins et al., 2004), linfócitos humanos (CarrilloVicco et al., 2004) e células do colostro humano (Pontes et al., 2006, 2007). A melatonina produzida nestes locais tem uma ação parácrina, autócrina e/ou intrácrina de proteção contra estresse oxidativo (para revisão, Luchetti et al., 2011) e modulação da resposta imunológica (para revisão, Carrillo-Vico et al., 2005a). Nessas condições a produção de melatonina atinge concentrações muito elevadas quando comparadas a produção rítmica da pineal.

A retina também produz melatonina de acordo com a iluminação ambiental, no entanto, esta não tem distribuição sistêmica (para revisão, Bailes \& Lucas, 2010). Nas demais fontes extra-pineais a produção desta indolamina é independente da iluminação ambiental (para revisão, Simonneaux \& Ribelayga, 2003). 
Evolutivamente, a função primária da melatonina está associada à sua capacidade citoprotetora, devido à sua propriedade antioxidante (Tan et al., 2007). Colocar as fontes extra-pineais de produção de melatonina como foco dos estudos reforça ainda mais esta evidência, pois a ação local desta indolamina está relacionada às suas propriedades de defesa do organismo.

Por ter sido descoberta primeiramente em glândulas pineais de vertebrados, durante três décadas, acreditava-se que a melatonina era um neurohormônio produzido apenas neste grupo. No entanto, hoje se sabe que a melatonina é produzida virtualmente em todos os grupos de seres vivos. A partir da década de 1990, diversos trabalhos descrevem a produção de melatonina por dinoflagelados (Poeggeler et al., 1991), bactérias (Manchester et al., 1995; Balzer et al., 2000), tripanossomídeos (Macías et al., 1999), plantas (Reiter et al., 2007; Paredes et al., 2009), fungos (Hardeland, 1999; Sprenger et al, 1999; Balzer et al., 2000) e alguns invertebrados (Hardeland \& Fuhrberg, 1996). Assim, não é justificável considerar a melatonina apenas como um neurohormônio.

Apesar de haver descrições de ritmo circadiano e/ou endógeno de melatonina em algumas espécies de bactérias (Manchester et al., 1995), essa característica não é comumente encontrada dentro deste reino. Dessa forma, Tan e colaboradores (2010) concluem que a função cronobiótica da melatonina de sinalizadora do ciclo claro/escuro apareceu posteriormente no processo evolutivo como resultado da incorporação da melatonina de bactérias e/ou algas fotossintéticas ancestrais ou ainda como um aparecimento independente que ocorreu em vários momentos da evolução.

O potencial antioxidante da melatonina está associada à sua capacidade de atuar diretamente como um "scavenger", sequestrando e reduzindo o potencial oxidativo de espécies reativas de oxigênio (ROS) ou nitrogênio (RNS), ou ainda à sua atuação sobre a 
síntese de enzimas antioxidantes. Esses efeitos são observados desde bactérias até mamíferos (para revisão, Tan et al., 2010). Em condições fisiológicas, a melatonina pode estimular transientemente a produção de baixas concentrações de ROS, que age como segundo mensageiro induzindo a transcrição gênica de moléculas citoprotetoras. Durante um quadro de estresse celular, como metabolismo acelerado e envelhecimento, a melatonina age diminuindo o dano mitocondrial, pois diminui a quantidade de ROS produzida pela mitocôndria, mantendo a concentração homeostática dessas moléculas (Hibaoui et al., 2009; para revisão, Luchetti et al., 2011). Em macrófagos, a melatonina diminui danos do DNA e da mitocôndria causados por peroxinitrito (Gilad et al., 1997), além de diminuir a ativação de ciclooxigenase-2 (COX-2) induzido por LPS (Mayo et al., 2005). Além disso, a melatonina reduz o nível de nitrito/nitrato induzido por elevadas concentrações de oxigênio em tecido broncopulmonário (Pan et al., 2009). Em cultura de células tronco mesenquimais, esta indolamina ainda aumenta a expressão de enzimas antioxidantes como a catalase e a peróxido desmutase 1 (Mias et al., 2008).

A melatonina age sobre a resposta inflamatória diminuindo a expressão da iNOS e, consequentemente, a produção de NO em célula epitelial do plexo coróide (Sivakumar et al., 2008), edema de pata (Marino et al., 2009; Esposito et al., 2010), macrófagos (Gilad et al., 1998), glioma (Esposito et al., 2008), tecido vascular (de Villa Bianca et al., 2004) e células de neuroblastoma (Choi et al., 2008). A melatonina ainda inibe a atividade das enzimas mieloperoxidase (Cuzzocrea et al., 2000; Galijasevic et al., 2008) e peroxidase (Slungaard \& Mahoney, 1991) de neutrófilos e eosinófilos, respectivamente, além de aumentar a proliferação de monócitos, linfócitos e células “natural killers" (para revisão, Carrillo-Vico et al., 2005a).

A melatonina também é considerada como um agente oncostático devido a sua capacidade imunomodulatória, antiproliferativa e antioxidante. Esta indolamina diminui a 
expressão do fator de crescimento endotelial vascular (VEGF, do inglês "vascular endothelial growth factor"), importante para o processo de angiogênese em tumores, e do fator de indução de hipóxia (HIF, do inglês "hipoxia-inducible factor"), essencial para a estimulação de VEGF (Dai et al., 2008). Além disso, a melatonina possui uma capacidade antiproliferativa induzindo a apoptose celular e o aumento do ciclo celular de células endoteliais do cordão umbilical humano (HUVECs, Cui et al., 2006, 2008). Por outro lado, a melatonina atua positivamente no processo de angiogênese e no reparo tecidual em lesões de pele (Soybir et al., 2003) e em modelo de isquemia renal (Mias et al., 2008).

\subsection{Via biossintética, controle circadiano da produção e via de degradação da melatonina}

Ao contrário das características funcionais da melatonina, sua via biossintética é altamente conservada dentre os diferentes grupos filogenéticos e tipos celulares. $\mathrm{O}$ triptofano captado da corrente sanguínea é convertido em 5-hidroxitriptofano (5-HTP) por meio da enzima triptofano hidroxilase 1 (TPH1). O 5-HTP é descarboxilado pela 5HTP descarboxilase em serotonina, a qual é convertida em N-acetilserotonina (NAS) pela enzima arilalquilamina $\mathrm{N}$-acetiltransferase (AA-NAT). Por fim, a NAS é transformada em melatonina pela ação da enzima hidroxi-indol-O-metiltransferase (HIOMT, para revisão, Simonneaux \& Ribelayga, 2003).

A serotonina é uma molécula que tem função de neurotransmissor e de hormônio parácrino e, portanto a enzima que transforma triptofano em serotonina é expressa de forma altamente disseminada (Gershon et al., 1999). A regulação das outras duas enzimas de síntese de melatonina é essencial para as funções rítmica e de defesa. A enzima limitante, que tem a menor velocidade de reação é a HIOMT, no entanto, a 
literatura sobre a regulação da AA-NAT é muito mais extensa, porque esta é a enzima controlada pela iluminação ambiental (Roseboom et al., 1996).

O mecanismo de regulação do equilíbrio do conteúdo da AA-NAT, dependente da informação luminosa, é determinado pelo controle da síntese do RNAm (mecanismo de bloqueio transcricional; Klein et al., 1997) ou pela degradação da proteína (mecanismo de bloqueio pós-traducional; Ganguly et al., 2001). Em roedores, o conteúdo noturno de RNAm da AA-NAT chega a ser 100 vezes superior que de dia (Borjigin et al., 1995; Coon et al., 1995). Já em ungulados, a enzima é sintetizada continuamente, no entanto, durante o dia a enzima é degradada (Schomerus et al., 2000). A noradrenalina liberada durante a fase de escuro é o sinal responsável pelo aumento da transcrição do RNAm da AA-NAT em roedores, e pela inibição da degradação desta enzima em ungulados (para revisão, Simonneaux \& Ribelayga, 2003). Assim, o controle luminoso da produção de melatonina ocorre na glândula pineal. Nas demais fontes extra-pineais de produção de melatonina, o mecanismo que regula a síntese desta indolamina ainda não é claramente esclarecido.

A sinalização luminosa que regula a produção da melatonina é um processo multissináptico que envolve a conversão da informação fótica em informações hormonais. A luminosidade captada pela retina é direcionada ao relógio central, os núcleos supraquiasmáticos (NSQ), dos quais se projetam inervações até a pineal. Durante a noite, esta glândula é estimulada por uma via simpática através da liberação de noradrenalina (Wurtman et al., 1967) e ATP (Mortani-Barbosa, 2000). A inibição da produção de melatonina durante o dia é imposta por uma sinalização inibitória GABAérgica, projetada dos NSQ para o núcleo paraventricular do hipotálamo (PVN, Kalsbeek et al., 1999, 2000; Teclemariam-Mesbah et al., 1999). 
A melatonina é uma molécula com elevado coeficiente de partição óleo-água. Quando produzida pela pineal, ela é liberada nos capilares sanguíneos se ligando à albumina (Cardinali et al., 1972). De maneira geral, a melatonina tem meia vida curta e é rapidamente metabolizada no fígado, onde é hidroxilada e conjugada ao sulfato formando a 6-sulfatoximelatonina pelo citocromo p450 (Tan et al., 2007). Outros estudos demonstram que este metabólito pode ser formado em outros locais como o sistema nervoso central, rins e coração (Lahiri et al., 2004). Aspectos quantitativos e qualitativos da produção de melatonina podem ser avaliados pelo perfil deste metabólito na urina ou no plasma (Arendt, 1982).

Além disso, a melatonina também pode ser convertida em outros metabólitos, tais como: $\mathrm{N}^{1}$-acetil-N²-formil-5-metoxikynuramina (AFMK) e $\mathrm{N}$-acetil-5metoxikynunamina (AMK, metabólito subseqüente ao AFMK). O AFMK foi primeiramente encontrado no tecido cerebral de ratos (Hirata et al., 1974), mas hoje já foi descrito em diversos outros tecidos. A melatonina pode ser convertida em AFMK por reações enzimáticas, pseudoenzimáticas e ainda por irradiação de ultravioleta e reação com ROS. Apesar de alguns trabalhos demonstrarem a ação direta da melatonina sobre as espécies reativas, muitos outros atribuem sua ação antioxidante aos metabólitos que são gerados durante o estresse oxidativo. A degradação de melatonina em AFMK e AMK eleva a ação de enzimas antioxidantes e inibe a ação de mediadores próinflamatórios (Silva et al., 2004; Mayo et al., 2005; Tan et al., 2007).

\subsection{Mecanismos de ação da melatonina}

Por ser lipossolúvel, a melatonina é capaz de atravessar diretamente a membrana celular podendo agir e regular alvos intracelulares, como a calmodulina (Benítez-King, 1993) e receptores intracelulares similares aos receptores nucleares retinóides (ROR $\alpha)$, 
modulando a transcrição gênica de genes envolvidos na resposta imune (Becker-Andre et al., 1994). Em 1997, foi publicada uma retratação sobre o fato de a melatonina agir sobre ROR $\alpha$. Segundo os autores, alguns desses dados não eram reprodutíveis (BeckerAndre et al., 1997). No entanto, posteriormente, diversos trabalhos demonstraram a capacidade da melatonina de atuar sobre os receptores nucleares RZR/ROR nos mais diversos tipos celulares (Garcia-Mauriño, 1998; Naji et al., 2004; Lardone et al., 2006; Caballero et al., 2008). Porém, esta controvérsia ainda persiste uma vez que alguns grupos de pesquisadores propõem que a ação da melatonina sobre receptores nucleares pode ser por uma ação indireta decorrente de uma cascata de sinalização gerada a partir da ligação com o receptor de membrana $\mathrm{MT}_{1}$ (Dai et al., 2001; Ram et al., 2002).

Por outro lado, a ação da melatonina sobre receptores de membrana é muito bem descrita e aceita. Esses receptores já foram descritos em todos os grupos de vertebrados e em mamíferos, atualmente, são descritos três subtipos. Os subtipos $\mathrm{MT}_{1}$ e $\mathrm{MT}_{2}$ pertencentes à família dos receptores acoplados à proteína $\mathrm{G}$, caracterizados por sete domínios transmembrânicos (Reppert et al., 1994, 1995; Dubocovich, 1988, 1997), e responsáveis pelos efeitos da melatonina sobre os NSQ (para revisão, Dubocovich et al., 2010). O terceiro subtipo é o receptor $M T_{3}$ (Dubocovich, 1988), o qual, posteriormente, foi caracterizado como sendo a enzima quinona redutase II (Nosjean et al., 2000). Esta enzima participa da proteção contra o estresse oxidativo, evitando reações de transferência de elétrons de quinonas (Foster et al., 2000).

\subsection{Eixo imune-pineal: uma comunicação bidirecional entre a}

\section{glândula pineal e o sistema imunológico}

A primeira evidência da relação entre a resposta imunológica e a melatonina foi relatada em 1926 por Berman que alimentou filhotes de gatos com glândula pineais 
bovinas. Esses animais tiveram melhor resistência às doenças infecciosas (para revisão, Carrillo-Vico et al., 2005a). Posteriormente, técnicas de pinealectomia cirúrgica e funcional demonstram que a ausência ou perda de função da glândula pineal acarretam hipertrofia dos órgãos imunológicos, como baço e timo, comprometendo a função de células imunocompetentes (Csaba \& Barath, 1975; Maestroni et al., 1986; Brainard et al., 1988; Jankovic et al., 1994). Nas últimas décadas do século XX, verificou-se a correlação entre o ritmo de produção da melatonina e alguns parâmetros imunológicos, que de maneira geral, apresentam um aumento na performance imunológica quando os dias são mais curtos (para revisão, Carrillo-Vico et al., 2005a).

Considerando que o ritmo de produção da melatonina marca a duração e intensidade do escuro (para revisão, Simonneaux \& Ribelayga, 2003) e que os organismos desenvolveram estratégias de sobrevivência às mudanças ambientais (Nelson \& Demas, 1996), este hormônio pode estar sinalizando para o sistema imune para que este possa se adaptar aos ciclos sazonais (Prendergast et al., 2003; Martin et al., 2008). Além disso, recentemente, diversos trabalhos apontam a melatonina como um mediador da resposta inflamatória e antioxidante (para revisão, Carrillo-Vico et al, 2005a; Markus et al., 2010; Luchetti et al., 2011). Dessa forma, nosso grupo propõe uma comunicação bidirecional entre a glândula pineal e a resposta inflamatória, colocando as funções cronobiótica e citoprotetora da melatonina em um mesmo contexto (para revisão, Markus et al., 2007). Este conceito foi denominado de eixo imune-pineal. Na realidade, Skwarlo-Sonta e colaboradores (2003) já haviam previsto que mediadores inflamatórios circulantes eram reciprocamente percebidos pela glândula pineal, regulando sua função.

Em suma, a hipótese do eixo imune-pineal prevê que em organismos saudáveis, a melatonina noturna age na periferia, sobretudo nas células endoteliais, reduzindo o 
rolamento e adesão de leucócitos. Frente a um estímulo inflamatório, seja por componentes bacterianos como LPS ou por mediadores inflamatórios endógenos, como o fator de necrose tumoral (TNF), a produção noturna de melatonina é inibida, permitindo a migração de leucócitos para o tecido inflamado (figura 4). Em uma terceira fase, quando a resposta inflamatória está solucionada, a produção rítmica de melatonina é restabelecida e a migração de leucócitos retorna aos níveis basais (para revisão, Markus et al., 2007).

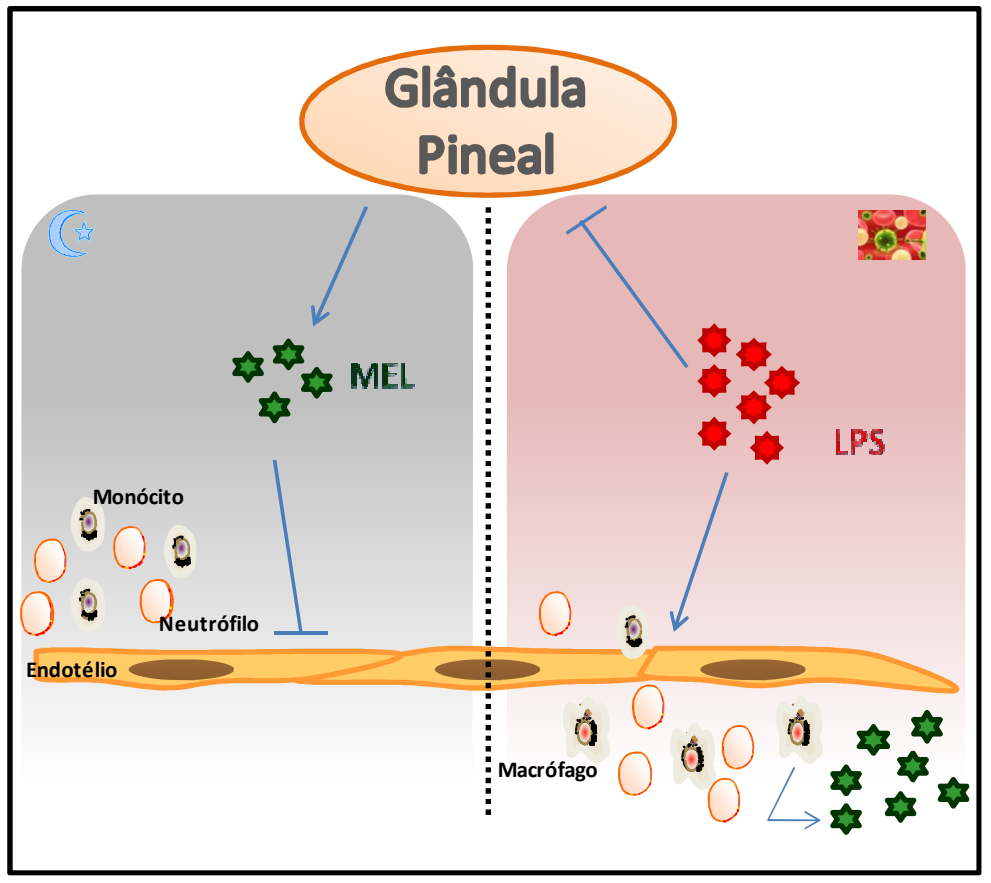

Figura 4 - Eixo imune-pineal, uma comunicação bidirecional entre a glândula pineal e o sistema imunológico. Em organismos saudáveis, a melatonina (MEL) produzida ritmicamente pela glândula pineal, age sobre as células endoteliais impedindo a migração de células imunocompetentes para o tecido adjacente (coluna da esquerda). Frente a um estímulo inflamatório, como lipopolissacarídeo (LPS) de bactérias gram-negativas, a produção de melatonina pela pineal é inibida (coluna da direita). Além disso, LPS ativa células endoteliais e células imunocompetentes, promovendo a migração destas últimas para o tecido lesionado. Neste local, essas células produzem melatonina em concentrações muito maiores que a produção noturna, na tentativa de solucionar o processo inflamatório evitando danos teciduais. 
O edema de pata de camundongos induzido por BCG apresenta um ritmo diário no tamanho da lesão. Quando estes animais foram pinealectomizados este perfil foi alterado, sendo restaurada com melatonina exógena. Neste mesmo trabalho, a produção de melatonina noturna foi inibida quando os animais foram submetidos à adrenalectomia, sugerindo a participação da adrenal no controle da produção rítmica deste hormônio (Lopes et al., 1997). Mais tarde, foi demonstrado que corticosteróides atuam sobre receptores de glicocorticóides aumentando e/ou restaurando a produção de melatonina (Fernandes et al., 2006, 2009).

A hipótese de que mediadores inflamatórios bloqueiam a produção noturna de melatonina é corroborada pelo fato de que o TNF bloqueia a transcrição gênica da enzima chave da síntese de melatonina (AA-NAT, Fernandes et al., 2006). Além disso, recentemente, foi demonstrado que a pineal está instrumentada para perceber estímulos inflamatórios como o LPS e o TNF, uma vez que expressam receptores TLR-4 (da Silveira Cruz-Machado, et al., 2010) e TNFR1 (Carvalho-Sousa et al., 2011), respectivamente. Juntamente, estes dados apontam a glândula pineal como alvo de mediadores inflamatórios, corroborando com a hipótese de uma comunicação bidirecional entre a pineal e a resposta inflamatória.

O fato da melatonina, em concentrações compatíveis com a produção noturna, atuar sobre o endotélio reduzindo sua reatividade (Lotufo et al., 2001, 2006), sugere que durante a produção rítmica de melatonina, o endotélio encontra-se menos ativado durante a noite. Para que ocorra a montagem de uma resposta inflamatória adequada, independente da hora do dia, este efeito da melatonina deve ser bloqueado. Além de o TNF inibir transientemente a transcrição da Aa-nat em glândula pineais de ratos (Fernandes et al., 2006), mulheres com mastite apresentam uma relação inversa entre a concentração de TNF e melatonina no colostro (Pontes et al., 2006). Além disso, LPS 
inibe a síntese de NAS e melatonina induzida por noradrenalina em cultura de pineal (da Silveira Cruz-Machado et al., 2010), dado ainda reforçado pelo fato de a produção rítmica de melatonina ser diminuída em quadros de infecção generalizada (Mundigler et al., 2002). Juntamente, esses dados indicam que frente a um estímulo inflamatório, a produção rítmica de melatonina é inibida de forma a não haver melatonina noturna circulante, para que haja a montagem de uma resposta inflamatória apropriada.

Durante a resposta inflamatória, células imunocompetentes ativadas são capazes de produzir melatonina localmente em concentrações mais elevadas. Linfócitos humanos em cultura possuem toda a maquinaria de biossíntese da produção de melatonina, sendo uma importante fonte de produção desta indolamina (Carrillo-Vico et al., 2004). Neste momento, a melatonina contribui para a resolução da resposta inflamatória. Além dos efeitos já mencionados acima, recentemente foi demonstrado que a melatonina atua sobre macrófagos humanos aumentando sua capacidade fagocítica (Pires-Lapa, 2010). Esta alternância entre a produção pineal e a produção periférica de melatonina, controlada pela mesma via de transcrição, indica que em ambos locais essa produção seja passível de ser controlada pelos mesmos fatores inflamatórios circulantes, resultando em um eixo de controle da resposta inflamatória.

Esse processo de resposta contra uma injúria aconteceria de maneira transiente, permitindo que o animal resolva uma infecção ou lesão tecidual de forma mais apropriada. O aumento de glicocorticóides circulante poderia favorecer o retorno da produção de melatonina pela glândula pineal (para revisão, Ferreira et al., 2005).

Um fator molecular importante na modulação da melatonina no contexto do eixo imune-pineal é o fator de transcrição NFKB, cuja função mais relevante, como mencionada anteriormente, está associada ao sistema imunológico, onde participa da regulação gênica de diversos mediadores importantes na resposta da imunidade inata e 
adquirida (Li \& Verma, 2002; Bonizzi \& Karin, 2004). O NFKB é encontrado no citoplasma de todos os tipos celulares na forma de dímeros. Quando as células não são estimuladas, os dímeros de NFKB são retidos no citoplasma pela associação com proteínas inibitórias da família IKB, impedindo sua translocação para o núcleo (Karin \& Bem-Neriah, 2000). Quando ativadas, uma cascata de sinalização intracelular culmina na ativação do complexo das quinases IKKs. Estas fosforilam a IKB que é degradada por proteassomas, induzindo a translocação do NFKB para o núcleo, favorecendo a transcrição de mediadores pró-inflamatórios (para revisão, Rothwarf \& Karin 1999; Ghosh \& Karin, 2002).

TNF e LPS inibem a produção de melatonina pela glândula pineal por ativarem o fator de transcrição NFKB (Fernandes et al., 2006; da Silveira Cruz-Machado et al., 2010). Por outro lado, corticosterona aumenta a produção de melatonina em pineal estimulada com noradrenalina, devido à inibição da translocação do NFKB (Ferreira et al., 2005). Esses achados permitem sugerir que o NFKB está envolvido na regulação da função pineal por fatores inflamatórios. Esse fator de transcrição é constitutivamente expresso na glândula pineal e apresenta um ritmo, no qual ocorre o aumento dos níveis de NFKB no núcleo durante a fase clara, e abrupta queda no início da fase escura (Cecon et al., 2010). Além disso, na periferia, o tratamento com melatonina diminuindo a produção de iNOS em macrófagos (Gilad et al, 1998), glioma (Esposito et al., 2008) e edema de pata (Esposito et al., 2010) também é resultado de uma atuação desta indolamina inibindo a translocação do NFKB. Outro processo regulado pela inibição deste fator de transcrição é a propriedade antiproliferativa da melatonina em HUVECs (Cui et al., 2008). 


\subsection{Endotélio como alvo privilegiado do eixo imune-pineal}

A produção de melatonina por células endoteliais ainda é controversa. Alguns trabalhos apontam o endotélio como fonte de melatonina (Kvetnoy, 1999), por outro lado, em estudos mais recentes, a expressão dos genes envolvidos na sua síntese, Hiomt e Aa-nat, não foi detectada (Silva et al., 2007). Esta controvérsia pode estar relacionada à diversidade das células endoteliais e dos protocolos experimentais empregados pelos diferentes autores. No entanto, os estudos sobre a ação da melatonina em células endoteliais são mais consistentes e revelam a capacidade deste hormônio em controlar o tônus vascular (Tamura et al., 2006, 2009; Silva et al., 2007) e a migração de leucócitos (Lotufo et al., 2001, 2006).

Os efeitos da melatonina observados sobre o endotélio podem ocorrer por diferentes mecanismos de ação, uma vez que acontecem em duas faixas de concentração: uma compatível com aquela encontrada na corrente sanguínea durante o pico noturno de produção deste hormônio (pM-nM; Lotufo et al., 2001; Tamura et al., 2006; Silva et al., 2007) e outra muito maior resultante de uma produção local de melatonina, como por exemplo por células imunocompetentes $(\mu \mathrm{M}-\mathrm{mM}$; Anwar et al., 2001; Pogan et al., 2002; Tamura et al., 2009).

A melatonina modula a vasodilação dos vasos sanguíneos. Melatonina $(0,1 \mathrm{mM})$ potencia o vasorelaxamento induzido por acetilcolina e inibe a contração induzida por norepinefrina e fenilefrina (Anwar et al., 2001). Por outro lado, em concentrações muito mais baixas (ao redor de nM), a melatonina potencia a vasoconstrição de artérias mamárias internas de humanos (Muller-Schweinitzer et al., 2004). Em ratos, ela inibe a vasodilatação induzida por bradicinina (Silva et al., 2007). O efeito de inibição sobre a dilatação pode estar sendo mediada pela capacidade da melatonina, em concentrações compatíveis com a produção noturna, inibir a produção de NO estimulada por 
bradicinina (Tamura et al., 2006), histamina e carbacol (Silva et al. 2007). Ainda há controvérsias quanto ao mecanismo de ação da melatonina em modular a expressão de eNOS. Nestes casos, a possibilidade da melatonina estar agindo sobre a interação $\mathrm{Ca}^{2+}$ CaM foi descartada, uma vez que a melatonina não mimetiza o efeito do calmidazólio, um inibidor de calmodulina, sobre os níveis de $\mathrm{Ca}^{2+}$ citoplasmático (Tamura et al., 2006). Essas controvérsias podem ser devido ao fato de a modulação da sinalização por $\mathrm{Ca}^{2+}$ pela melatonina ser dependente do estado de ativação das células endoteliais (Pogan et al., 2002).

A melatonina agindo sobre o endotélio também modula a montagem da resposta inflamatória. Melatonina, em concentrações compatíveis com a produção noturna, reduz o aumento da permeabilidade vascular e a adesão de neutrófilos in vitro induzidas por leucotrieno $\mathrm{B}_{4}$ (Lotufo et al., 2006). Ainda na mesma faixa de concentração, a melatonina diminui o rolamento e adesão de neutrófilos em vênulas pós-capilares analisadas por microscopia intravital (Lotufo et al., 2001). Já em concentrações mais elevadas, melatonina inibe a expressão de moléculas de adesão induzida por TNF (Sasaki et al., 2002) e a expressão da iNOS induzida por LPS (Tamura et al., 2009). Esses dois últimos efeitos são decorrentes da inibição da translocação do NFKB. Nestes casos, a melatonina extra-pineal, decorrente da produção por células imunocompetentes, pode estar atuando sobre as células endoteliais, combatendo a injúria tecidual.

Os mecanismos de ação pelos quais a melatonina estaria atuando sobre as células endoteliais ainda são controversos. Segundo Silva e colaboradores (2007), não há transcrição do RNAm para o receptor de melatonina $\mathrm{MT}_{2}$ em células endoteliais em cultura. Por outro lado, ensaios farmacológicos sugerem que os efeitos sobre o rolamento e adesão de neutrófilos são mediados por receptores de melatonina dos tipos $\mathrm{MT}_{2}$ e $M T_{3}$. O análogo seletivo para receptores $\mathrm{MT}_{2}$ (4P-PDOT) mostra o mesmo perfil 
de redução do rolamento de neutrófilos que a melatonina, enquanto que o uso do antagonista não seletivo, luzindol, impede o efeito de ambos agonistas. O precursor da melatonina, NAS, que possui maior afinidade pelo receptor $M T_{3}$ que a melatonina, e o agonista seletivo para este subtipo, 5-MCA-NAT, inibiram a adesão de neutrófilos. Assim, o efeito da melatonina observado sobre o rolamento é decorrente da ativação do receptor $\mathrm{MT}_{2}$, enquanto que a adesão é mediada pela ativação de receptores $M T_{3}$ (Lotufo et al., 2001). Já os efeitos sobre a inibição da eNOS, a utilização de agonistas (4P-PDOT e 5-MCA-NAT) não obteve o mesmo efeito inibitório que a melatonina. Além disso, luzindol não bloqueou a ação da melatonina na síntese de NO, sugerindo que, nestes casos, a melatonina não atua sobre receptores de membrana (Tamura et al., 2006, 2009).

\section{MEMÓRIA CELULAR}

A memória é a capacidade de reter idéias, sensações e impressões adquiridas anteriormente. Essa capacidade é atribuída à associações cognitivas complexas, presentes em alguns grupos de animais, que se integra, sobretudo, no hipotálamo. Assim, trata-se da comunicação de todo um sistema, interligado por conexões neuronais (para revisão, Bibb et al., 2010). Porém, atualmente, este conceito tem sido extrapolado para níveis estruturais mais baixos, como o nível celular.

A capacidade de armazenar informações por um período de tempo e responder diferentemente da porção que não recebeu tais informações é comumente conhecida em células imunológicas do tipo B. Essas células, quando estimuladas por um produto antigênico, são capazes de reter informações de maneira que apresentem uma sinalização de ativação diferente das células "naïve" (células não estimuladas). Células B "naïve" requerem três mecanismos de sinalização diferentes para serem ativadas, 
enquanto que células B com memória podem ser ativadas por mecanismo independente de anticorpo, aumentando sua proliferação e diferenciação (para revisão, Lanzavecchia et al., 2006). Essa capacidade de reter as informações expostas previamente permitiu avanços importantes na medicina, como a imunização por vacinas (para revisão, Sallusto et al., 2010).

Por outro lado, nos demais tecidos e sistemas, essa condição não é devidamente destacada. De maneira geral, na literatura, a memória celular aparece discretamente e os autores não lhe atribuem um achado científico importante. Células tronco neurais obtidas da zona subventricular de animais com lesão neural induzida, têm maior capacidade de proliferação in vitro que células obtidas de animais saudáveis. Essa capacidade foi atribuída à presença de microglias nas culturas de células tronco neurais provenientes de animais lesionados. Fatores produzidos por células da microglia devem estar primando as células tronco, uma vez que estas, quando oriundas de animal saudável, e incubadas com meio condicionado de células de animais lesionados, apresentam a mesma capacidade proliferativa que células tronco originalmente obtidas de animais com lesão cerebral (Deierborg et al., 2010).

Células endoteliais obtidas de animais adrenalectomizados e cultivadas por aproximadamente 16 dias, aderem menos neutrófilos que células oriundas de animais falso-operados ou "naïve". Assim, a deficiência de glicocorticóides modula as funções adrenais, afetando a capacidade de adesão de leucócitos por células endoteliais. Essas informações são armazenadas e preservadas in vitro mesmo após todas as condições de cultura (Cavalcanti et al., 2007).

Células endoteliais derivadas da gordura subcutânea de pacientes com malária cerebral ou malária sem complicações, não apresentaram diferenças na expressão de ICAM-1, VCAM-1 e CD61. No entanto, quando estimuladas por TNF, a expressão 
dessas moléculas e da caspase-1 são maiores em células obtidas de pacientes com malária cerebral do que células de pacientes com malária sem complicação. Contudo, o autor não acredita que o estado de maior ativação de células endoteliais obtidas de pacientes com malária cerebral seja atribuído à maior severidade da doença. Para ele, as células não teriam a capacidade de armazenar as informações do doador após as condições de cultura, e as diferenças de respostas por ele observadas, seriam decorrentes apenas da diversidade de herança genética entre os indivíduos, no que diz respeito à capacidade de resposta de suas células endoteliais ao estímulo pró-inflamatório (Wassmer et al., 2011).

A capacidade de memória de células endoteliais também foi observada por Wang e colaboradores (2011). Células endoteliais formadoras de colônias obtidas de pacientes com doença arterial coronariana foram cultivadas por até 10 passagens in vitro. Nas passagens de 3 a 5 estas células exibiram maior expressão fenotípica endotelial e melhores funções biológicas, referentes à produção de NO e formação de tubos, respectivamente, quando comparadas a células oriundas de um número maior de passagens. Nesta última condição, a capacidade de ativação frente ao estímulo inflamatório é maior. Além disso, quando comparada com o controle, células provenientes de pacientes com alguma complicação como hipertensão, doença coronariana e diabetes mellitus, estavam em maior estado de ativação, mesmo sem estimulação in vitro. Dessa forma, tanto o número de passagens in vitro quanto as condições clínicas do pacientes afetam a pureza, função biológica e potencial de ativação em células endoteliais (Wang et al., 2011). 


\section{CONSIDERAÇÕES FINAIS}

Considerando que as células endoteliais formam a interface entre a corrente sanguínea e o tecido adjacente e que constituem a porta de entrada da resposta imunológica, este projeto se baseia na hipótese de que as células endoteliais possam apresentar um ritmo em sua maquinaria que altere a intensidade da resposta frente a um quadro de inflamação.

A constatação de que essas células são capazes de preservar as informações das condições do doador juntamente com o fato de possuírem uma localização privilegiada na circulação, sendo alvo potencial da melatonina circulante e de mediadores inflamatórios, constitui a base para a formulação da nossa hipótese de trabalho. Dessa forma, será que a reatividade de células endoteliais apresentaria uma variação de acordo com o horário em que essas células fossem obtidas? A inibição da produção noturna de melatonina por um processo inflamatório seria capaz de reverter o possível efeito desta indolamina sobre as células endoteliais?

Nesta dissertação foi avaliado se a hora de morte e se manipulações prévias do animal doador alteram a reatividade de células endoteliais mantidas em cultura. Por participar da regulação de processos fisiológicos e fisiopatológicos, diversos estudos têm focado as células endoteliais como alvo de investigação. Nosso grupo tem investigado o efeito provocado pela melatonina sobre o endotélio e questionado qual o potencial terapêutico desse hormônio sobre essas células. A importância deste trabalho se faz pela tentativa de buscar a otimização dos estudos de terapia celular, visto que ele colabora na investigação do efeito da melatonina endógena sobre a biologia das células endoteliais, abrindo novas perspectivas para o desenvolvimento de estratégias de controle de disfunções endoteliais. Além disso, a análise das características das células 
endoteliais obtidas de animais mortos durante o dia ou a noite possibilitou o melhor entendimento dos efeitos da melatonina sobre o organismo. 


\section{OBJETIVOS}

O objetivo geral da presente dissertação foi verificar a reatividade de células endoteliais em cultura obtidas de animais mortos durante o dia e a noite e a relação da melatonina com as possíveis diferenças entre as mesmas. Para isso, foram analisados:

1. O efeito da melatonina na concentração plasmática de TNF;

2. O perfil de inibição da produção noturna de melatonina pelo LPS, verificando a concentração plasmática de melatonina e a transcrição gênica da enzima AA-NAT na pineal após duas ou seis horas do tratamento;

3. O efeito ex vivo do LPS na reatividade de células endoteliais, verificando a expressão de moléculas de adesão e iNOS e a capacidade de adesão de neutrófilos;

4. A reatividade de células endoteliais de acordo com o horário de obtenção, verificando a expressão de moléculas de adesão e iNOS e a capacidade de adesão de neutrófilos em células obtidas de animais mortos de dia ou à noite;

5. O efeito do LPS quando administrado durante o dia;

6. A concentração plasmática de melatonina de acordo com a reatividade de células endoteliais. 


\section{$\mathcal{M A T}$ TRIAL $\mathcal{E} \mathcal{M} \mathcal{E} \mathcal{T} O D O S$}




\section{III. $\mathcal{M} \mathcal{A} \mathcal{T} \mathcal{E} \mathcal{R} \mathcal{A} \mathcal{L} \mathcal{E} \mathcal{M} \mathcal{E} \mathcal{T} O D O S$}

\section{Animais}

Em todos os experimentos foram utilizados ratos (Rattus novergiccus) machos da linhagem Wistar com dois meses de idade, pesando entre 200 e 300 g. Os animais foram criados e mantidos no biotério do Instituto de Biociências da Universidade de São Paulo em condições controladas de temperatura e umidade, recebendo água e ração $a d$ libitum. O ciclo claro/escuro empregado foi o de 12/12 h (luzes acesas às 07h00 e apagadas às 19h00), sendo o horário do acender das luzes considerado como "Zeitgeber Time" zero (ZT0).

Os experimentos foram realizados de acordo com os princípios éticos de utilização de animais para pesquisa, cujo protocolo experimental foi aprovado pela Comissão de Ética no Uso de Animais (CEUA) do Instituto de Biociências da Universidade de São Paulo (protocolo 089/2009; anexo 1).

\section{Drogas e reagentes}

As drogas e reagentes utilizados nos procedimentos experimentais estão listados a seguir, de acordo com a procedência.

- Amresco (Solon, Ohio, EUA): Triton X-100.

- BD Pharmingen (San Diego, CA, EUA): Anticorpo monoclonal de rato para CD-54 (ICAM-1) conjugado à isotiocianato de fluoresceína (FITC) e CD-31 (PECAM-1) conjugado à ficoeritrina (PE).

- Beker (Embu, Brasil): Água estéril para injeção (RNAse free).

- Bio-Rad Laboratories (Hercules, CA, USA): SYBR Green. 
- Biosource Internatinal Inc. (Camarillo, CA, USA): "Primers" (senso e antisenso) para Aa-nat (5'-AGCGCGAAGCCTTTATCTCA-3' e 5'- AAGTGCCGGATC TCATCCAA-3').

- eBioscience (San Diego, CA, EUA): Rat TNF-alpha ELISA ready-set-go kit.

- GIBCO BRL Products (Grand Island, NY, EUA): DMEM, gentamicina, pancreatina e soro fetal bovino.

- IBL International (Hamburgo, Alemanha): Melatonin ELISA kit.

- Integrated DNA Technologies Inc. (San Diego, CA, USA): "Primers" (senso e antisenso para 18S: (5'-CGGCTACCACATCCAAGGAA-3' e 5'GCTGGAATTA CCGCGGCT-3').

- Invitrogen Life Technology (Carlsbad, CA, USA): $\mathrm{H}_{2} \mathrm{O}_{2}$ (peróxido de hidrogênio), Randon Primers, SuperScript II, Trizol, dNTPs, tampão para PCR $(5 x)$.

- Merck (São Paulo, Brasil): Álcool etílico.

- Santa Cruz Biotechnology (Saint Cruz, CA, EUA): Anticorpo policlonal de coelho para NOS2 (iNOS) conjugado à tetrametil rodamina isotiocianato (TRITC).

- Sigma-Aldrich (Saint Louis, MO, EUA): EDTA (ácido etileno diamino tetracético), LPS (Escherichia colli, sorotipo 0127:B8), melatonina, percoll, tetrametilbenzidina (TMB).

\section{Preparo de drogas}

LPS foi preparado na concentração de $0,5 \mathrm{mg} / \mathrm{mL}$, diluído em solução salina (0,9\% de $\mathrm{NaCl}$ diluído em água deionizada purificada por sistema Milli-Q - Millipore®, Billerica, MA, EUA) acrescida de 5\% de álcool etanol. 
A melatonina foi preparada na concentração de $3,0 \mathrm{mg} / \mathrm{mL}$, diluída em solução salina acrescida de 5\% de álcool etanol. Para o tratamento de LPS + melatonina, após diluição separada, ambas as soluções foram misturadas para que a administração fosse feita na mesma injeção.

\section{Protocolo experimental}

De acordo com o tratamento recebido, os animais foram divididos nos seguintes grupos: animais não tratados ("naïve"), tratados com veículo (salina 0,9\% + etanol 5\%), LPS $(0,5 \mathrm{mg} / \mathrm{kg})$ ou LPS + melatonina $(3,0 \mathrm{mg} / \mathrm{kg}$, LPS+MEL). O tratamento foi realizado por via endovenosa (veia caudal) duas ou seis horas antes da morte. Os animais foram mortos seis horas após o apagar das luzes (ZT18), correspondente ao pico de produção noturna de melatonina, ou seis horas após o acender das luzes (ZT6), correspondente a 12 horas de diferença do pico de produção noturna de melatonina. Dessa forma, obtivemos grupos experimentais cuja morte dos animais foi realizada na fase de escuro ou de claro. Animais mortos à noite receberam tratamento no ZT16 e ZT12, ou seja, duas e seis horas antes da morte, respectivamente. Da mesma forma, animais mortos de dia foram tratados no ZT4 ou ZT0 (figura 5). 
$\mathbf{A}$

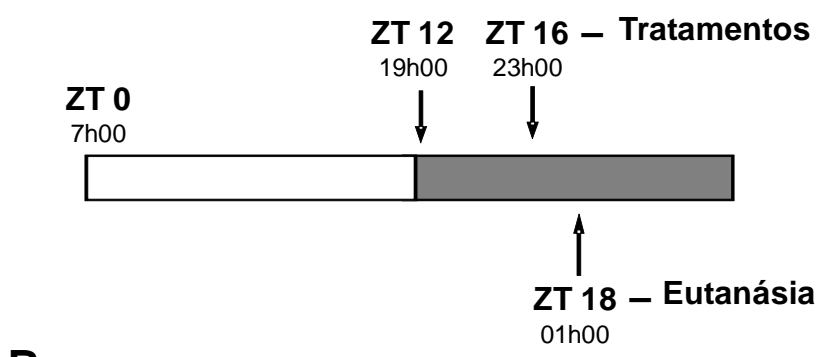

B

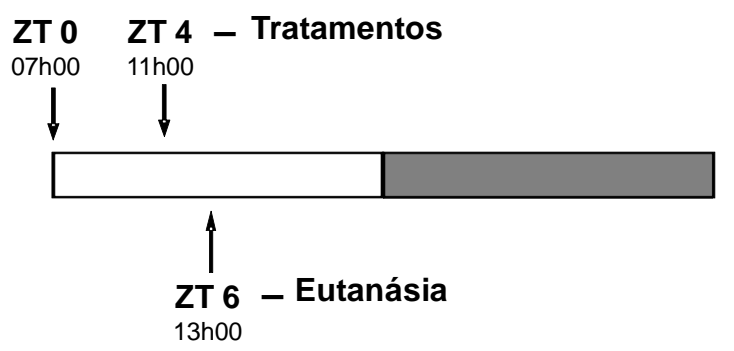

Grupos:
•Naïve
•Veículo
•LPS $0,5 \mathrm{mg} / \mathrm{kg}$
•LPS $0,5 \mathrm{mg} / \mathrm{kg}+$ MEL $3,0 \mathrm{mg} / \mathrm{kg}$

Figura 5 - Esquema representativo do protocolo experimental utilizado neste trabalho. De acordo com o tratamento, a animais foram divididos nos seguintes grupos: sem tratamento ("naïve"), tratados com veículo (salina 0,9\% + etanol 5\%), tratados com LPS (0,5 mg/kg) ou LPS + melatonina $(3,0 \mathrm{mg} / \mathrm{kg}$, LPS+MEL). Os animais foram mortos à noite (ZT18) após duas (ZT16) ou seis horas (ZT14) de tratamento (A) ou de dia (ZT6) após duas (ZT4) ou seis horas (ZT0) de tratamento.

\section{Dosagem de melatonina e TNF plasmáticos}

O sangue da aorta abdominal dos animais foi obtido no momento da decapitação (aproximadamente $3 \mathrm{~mL}$ ) utilizando tubos de ensaios $(15 \mathrm{~mL}$ ) contendo cerca de 100 $\mu \mathrm{L}$ de EDTA $(0,5 \mathrm{mM}, \mathrm{pH} 8,0)$, a fim de evitar a coagulação. $\mathrm{O}$ sangue foi centrifugado (2000 x g, $40 \mathrm{~min}$ ) para a obtenção do plasma o qual foi congelado a $-80^{\circ} \mathrm{C}$ até o momento do uso.

As concentrações plasmáticas de TNF e melatonina foram quantificadas com conjunto de diagnóstico comercial ("rat TNF-alpha ELISA ready-set-go kit", 
eBioscience e "melatonin ELISA kit", IBL International, com limite de detecção de 8,0 $\mathrm{pg} / \mathrm{mL}$ e 3,0 pg/mL, respectivamente) por meio da técnica imunoenzimática conhecida como ELISA (do inglês, "enzyme-linked immunosorbent assay"), de acordo com as instruções do fabricante. As placas foram lidas em espectrofotômetro (SpectraMAX 250, Molecular Devices, CA, EUA) à $450 \mathrm{~nm}$ para TNF e $405 \mathrm{~nm}$ para melatonina.

\section{Extração do RNA total}

As glândulas pineais dos animais foram coletadas no momento da morte e congeladas a seco a $-80^{\circ} \mathrm{C}$ até o momento do uso. A extração do RNA total foi realizada utilizando o reagente Trizol $(1,0 \mathrm{~mL})$. Após homogeneização, foi adicionado clorofórmio $(100 \mu \mathrm{L})$, e a amostra agitada manualmente e mantida por três minutos à temperatura ambiente. Posteriormente, a amostra foi centrifugada (12000 x g, $15 \mathrm{~min}$, $4^{\circ} \mathrm{C}$ ) e o extrato de RNA total retido na fase aquosa foi transferida para outro tubo. A precipitação do RNA foi feita com isopropranol $(250 \mu \mathrm{L}, 10 \mathrm{~min}$, TA) seguida de centrifugação $\left(12000 \mathrm{x} \mathrm{g}, 10 \mathrm{~min}, 4^{\circ} \mathrm{C}\right)$. O sobrenadante foi removido e o "pellet" lavado duas vezes com etanol $(75 \%)$ e novamente centrifugado $\left(7500 \mathrm{x} \mathrm{g}, 5 \mathrm{~min}, 4^{\circ} \mathrm{C}\right)$. $\mathrm{O}$ excesso de etanol foi evaporado à temperatura ambiente por 10 minutos. Para melhor purificação das amostras, o "pellet" foi ressuspenso em solução aquosa de acetato de sódio $(10 \%, 1 \mathrm{M}, \mathrm{pH} 5,2)$ e etanol $(2,5 \%)$ e mantido a $-20^{\circ} \mathrm{C}$ por 18 horas. Após este período, a amostra foi novamente centrifugada $\left(20000 \mathrm{x} \mathrm{g}, 30 \mathrm{~min}, 4^{\circ} \mathrm{C}\right)$ e o RNA foi ressuspenso em água estéril para injeção (RNAse "free"). A quantificação do RNA total foi feita pelo espectrofotômetro ND-1000 (Nanodrop, Wilmintong, DE, EUA). 


\section{RT-PCR}

A construção do DNA complementar (cDNA) foi realizada utilizando-se 1,0 $\mu \mathrm{L}$ de "primers" randômicos $(50 \mathrm{ng}), 1,0 \mu \mathrm{L}$ de dNTPs $(10 \mathrm{mM}), 0,5 \mu \mathrm{g}$ de RNA total extraído e água de injeção (RNAse "free") até completar o volume final de $13 \mu \mathrm{L}$. As amostras foram incubadas a $65^{\circ} \mathrm{C}$ por 5 min (termociclador Eppenfort $\AA$ ) e resfriadas em banho de gelo. Em seguida, adicionou-se 4,0 $\mu \mathrm{L}$ de tampão para PCR (5x), 1,0 $\mu \mathrm{L}$ de ditiotreitol e 1,0 $\mu \mathrm{L}$ da enzima transcriptase reversa SuperScript II (200U/ $\mu \mathrm{L})$. Para geração do cDNA, as amostras foram incubadas por $5 \min$ a $25^{\circ} \mathrm{C}, 55 \min$ a $50^{\circ} \mathrm{C}$ e 15 min a $10^{\circ} \mathrm{C}$ (termociclador Eppenfort $\left.{ }^{\circledR}\right)$. $\mathrm{O}$ cDNA resultante foi armazenado a $-20^{\circ} \mathrm{C}$ até o momento do uso.

\section{Determinação da transcrição do gene Aanat por RT-PCR em}

\section{tempo real}

A transcrição do gene que codifica a enzima AA-NAT foi determinada pela incubação do cDNA construído $(1,0 \mu \mathrm{L})$ com os "primers" senso e antisenso (330 nM) e com iQ SYBER Green Supermix (mix 2x, 50\% do volume final, $20 \mu \mathrm{L}$ ), que contém, entre outros componentes, a iTaq DNA polimerase. A normalização interna dos dados foi feita utilizando-se "primers" específicos $(25 \mathrm{nM})$ da proteína ribossomal 18S. A fluorescência deste ensaio foi obtida pelo fluoróforo Syber Green que se intercala ao DNA dupla-fita.

A amplificação da transcrição do gene da Aanat, foi realizada pelo aparelho iCycler (BioRad Laboratories $\left.{ }^{\circledR}\right)$. A denaturação $\left(7 \mathrm{~min}, 95^{\circ} \mathrm{C}\right)$ foi seguida por 40 ciclos de amplificação (10 s de denaturação a $95^{\circ} \mathrm{C}$ e 1 min de anelamento e elongamento a $60^{\circ} \mathrm{C}$ ). A amplificação de produtos inespecíficos foi verificada por "melting curves" 
feita ao final do experimento e analisadas para cada amostra. Nesta fase, a temperatura baixa $1{ }^{\circ} \mathrm{C}$ a intervalos de tempo determinados e o pico de fluorescência é obtido em cada poço, numa temperatura que coincide com o Tm (do inglês, "melting temperature") do produto esperado. A presença de produtos inespecíficos é averiguada quando picos de fluorescência em Tms diferentes da curva são formados. Água e RNA de pineais não incubadas com transcriptase reversa foram utilizadas como controle negativo.

Os "primers" (senso e antisenso) utilizados para Aanat e 18S foram: 5'AGCGCGAAGCCTTtATCTCA-3'， 5'-AAGTGCCGGATCTCATCCAA-3’， 5' CGGCTACCACATCCAAGGAA-3' e 5'-GCTGGAATTACCGCGGCT-3', respectivamente.

A concentração do RNAm foi calculada usando-se o valor do "threshold cycle" (Ct) da amplificação dos genes alvos. A quantificação relativa foi feita pela fórmula $2^{-}$ $\Delta \Delta \mathrm{Ct}$, onde $\Delta \Delta \mathrm{Ct}$ representa a diferença entre os ciclos normalizada pela referência interna (18S) e um calibrador (glândulas pineais de animais mortos de dia).

\section{Cultura de células endoteliais}

O procedimento de isolamento de células endoteliais foi realizado segundo adaptação do protocolo de Chen e colaboradores (1995), mais recentemente descrito por Tamura e colaboradores (2010). As células endoteliais são obtidas por migração celular da microcirculação sanguínea do músculo cremaster, responsável pelo recobrimento dos testículos.

Os animais foram mortos por decapitação e os corpos banhados em etanol $70 \%$. O músculo cremaster foi retirado utilizando pinça e tesoura cirúrgicas e lavado em PBS (do inglês "phosphate buffer saline", composição: $\mathrm{NaCl} 125 \mathrm{mM}, \mathrm{Na}_{2} \mathrm{HPO}_{4} 2 \mathrm{mM}$, 
$\mathrm{NaH}_{2} \mathrm{PO}_{4} 2 \mathrm{mM}$ e $\mathrm{KCl} 5 \mathrm{mM}$ ). Em ambiente estéril, o tecido foi novamente lavado e cortado em pedaços de aproximadamente $2 \times 2 \mathrm{~mm}$. Em uma placa de 24 poços foram colocados dois pedaços por poço e após aproximadamente cinco minutos foram cobertos com $700 \mu \mathrm{L}$ de meio DMEM suplementado com $20 \%$ de soro fetal bovino. As placas foram mantidas em estufa $\left(37^{\circ} \mathrm{C}, 5 \% \mathrm{CO}_{2}\right)$ e os tecidos foram retirados após 48 horas.

Segundo Chen, somente as células endoteliais migram para a placa neste período de incubação. Células sanguíneas são excluídas após trocas de meio. Além disso, este procedimento já foi caracterizado por nosso grupo através de marcadores específicos de células endoteliais (anti-fator de Von Willebrand e anti-CD31).

Após a retirada dos tecidos, as células endoteliais são mantidas em estufa e o meio trocado a cada 48 horas. Ao atingirem confluência, após aproximadamente 16 dias, as células são utilizadas para os ensaios de imunocitoquímica e adesão de neutrófilos in vitro. Para isso, poços em confluência são selecionados, lavados com PBS e as células são soltas por estímulo mecânico junto com pancreatina (1:9 diluída em PBS) por cinco minutos. A utilização da pancreatina é menos agressiva que a tripsina. A ação da pancreatina é bloqueada pela adição de 1,0 mL de meio DMEM suplementado com soro fetal bovino (20\%). As células são então replaqueadas na concentração de 1,0 x $10^{4}$ células por poço em um volume total de $200 \mu \mathrm{L}$ em lâminas com 8 poços (LabTek "chamber slide", Nalge Nunc International, NY, EUA) e placas de 96 poços para ensaio de adesão.

\section{Ensaio de imunocitoquímica por microscopia confocal}

Para os ensaios descritos abaixo, foram utilizadas células de primeira passagem após 48 horas do plaqueamento. 
Para a quantificação da expressão da enzima iNOS as células foram lavadas, fixadas com solução acetona + metanol $\left(1: 1,-20^{\circ} \mathrm{C}, 15 \mathrm{~min}\right)$ e permeabilizadas com incubação com 0,2\% Triton-x100 diluído em PBS (30 min, TA) para posterior incubação com anticorpo anti-NOS2 conjugado a TRITC (1:50, overnight, Santa Cruz Biotechnology).

Para quantificar a expressão das moléculas de adesão, ICAM-1 e PECAM-1, as células foram incubadas com os anticorpos anti-CD54 conjugado a FITC (1:50, $4^{\circ} \mathrm{C}, 20$ min, BD Pharmingen) ou anti-CD31 conjugado a $\mathrm{PE}\left(1: 50,4^{\circ} \mathrm{C}, 20 \mathrm{~min}, \mathrm{BD}\right.$ Pharmingen), respectivamente. Posteriormente, foram fixadas com solução acetona + metanol $\left(1: 1,-20^{\circ} \mathrm{C}, 15 \mathrm{~min}\right)$. Como controle positivo, células endoteliais obtidas de animais "naïve" e mortos durante o dia foram incubadas com LPS $(1,0 \mu \mathrm{g} / \mathrm{mL}, 4 \mathrm{~h})$. Este procedimento foi realizado para cada ensaio independente.

Todas as lâminas foram montadas com solução glicerol diluída em PBS (1:1), e a leitura realizada em microscopia confocal (LSM 510; Carl Zeiss, Jena, Germany). A marcação realizada com TRITC foi excitada a $543 \mathrm{~nm}$ (laser HeNe) e a fluorescência observada com um filtro de emissão de 560-575 nm. FITC e PE foram excitados a 488 nm (laser Argônio) e $543 \mathrm{~nm}$ e as fluorescências emitidas a 515-530 nm e 560-575 nm, respectivamente.

Para a quantificação da expressão da iNOS, ICAM-1 e PECAM-1, foram selecionados aleatoriamente três campos de cada cultura contendo de 4-6 células. A quantificação foi realizada utilizando o aplicativo ROI do software LSM 510 (Carl Zeiss, Jena, Germany), o qual seleciona a área de cada célula e quantifica a fluorescência emitida. 


\section{Obtenção de neutrófilos}

Neutrófilos foram obtidos a partir do sangue (cerca de $10 \mathrm{~mL}$ ) retirado com seringa contendo aproximadamente $100 \mu \mathrm{L}$ de EDTA $(0,5 \mathrm{M}, \mathrm{pH} 8,0)$ da aorta de ratos machos anestesiados por inalação de éter. O uso do éter faz-se necessário para otimização da obtenção dos neutrófilos, reduzindo a quantidade de animais necessários para o experimento. Os polimorfonucleares $(\mathrm{PMN})$ foram recuperados por extração de Percoll: $5 \mathrm{~mL}$ de sangue adicionado a $3 \mathrm{~mL}$ de Percoll (Sigma) 56\% em PBS. Após a centrifugação 1000 x g por 40 min, a interface contendo os polimorfonucleares foi retirada e os eritrócitos foram lisados por choque hipotônico em solução de lise $\left(\mathrm{NH}_{4} \mathrm{Cl}\right.$ 8,3 g/L, $\left.\mathrm{NaHCO}_{3} 1,0 \mathrm{~g} / \mathrm{L}\right)$ após centrifugação $\left(1500\right.$ x g, $\left.10 \mathrm{~min}, 4^{\circ} \mathrm{C}\right)$. Este método permite a obtenção de uma solução com aproximadamente $80 \%$ de neutrófilos. As células foram ressuspensas em solução salina de Hanks balanceada (HBSS, composição em g/L: $\mathrm{NaCl}$ 8,12; $\mathrm{KH}_{2} \mathrm{PO}_{4}$ 0,06; $\mathrm{MgSO}_{4} .7 \mathrm{H}_{2} \mathrm{O}$ 0,246; $\mathrm{CaCl}_{2} \quad 0,14 ; \mathrm{NaHCO}_{3}$ 0,25; $\mathrm{Na}_{2} \mathrm{HPO}_{4}$ 0,071; $\mathrm{KCl} 0,4$; glicose 1,00).

\section{Ensaio de adesão neutrófilo-endotélio in vitro}

Como descrito anteriormente, as células endoteliais dos diferentes grupos foram repassadas para placa de 96 poços na concentração de $1,0 \times 10^{4}$ células/poço $(200 \mu \mathrm{L}$ /poço) e mantidas em estufa $\left(37^{\circ} \mathrm{C}, \quad 5 \% \quad \mathrm{CO}_{2}\right)$ até atingirem confluência (aproximadamente cinco dias).

As células foram lavadas com solução HBSS e os neutrófilos adicionados (50 $\mu \mathrm{L}$ /poço contendo $5,0 \times 10^{4}$ neutrófilos/poço) e incubados por $30 \mathrm{~min}$. Após este período os neutrófilos não aderidos foram retirados por lavagem com HBSS. Foram então adicionados $50 \mu \mathrm{L}$ de tampão fosfato contendo $0,5 \%$ do agente solubilizante hexadeciltrimetilamonio. 
A quantidade de polimorfonucleares aderidos foi avaliada pelo ensaio colorimétrico de dosagem da enzima mieloperoxidase, realizado da seguinte maneira: incubação por $5 \mathrm{~min}$ com tetrametilbenzidina (TMB, 1,6 mM, $25 \mu \mathrm{L}$ ) seguido de incubação por 2 min com $\mathrm{H}_{2} \mathrm{O}_{2}(0,5 \mathrm{mM}, 100 \mu \mathrm{L})$. A velocidade da reação foi reduzida por adição de $\mathrm{H}_{2} \mathrm{SO}_{4}(1 \mathrm{M}, 50 \mu \mathrm{L})$. A absorbância foi determinada em leitor (SpectraMAX 250, Molecular Devices, CA, EUA) em $450 \mathrm{~nm}$. A quantidade de células aderidas foi determinada utilizando-se uma curva padrão com quantidades conhecidas de neutrófilos (figura 6).

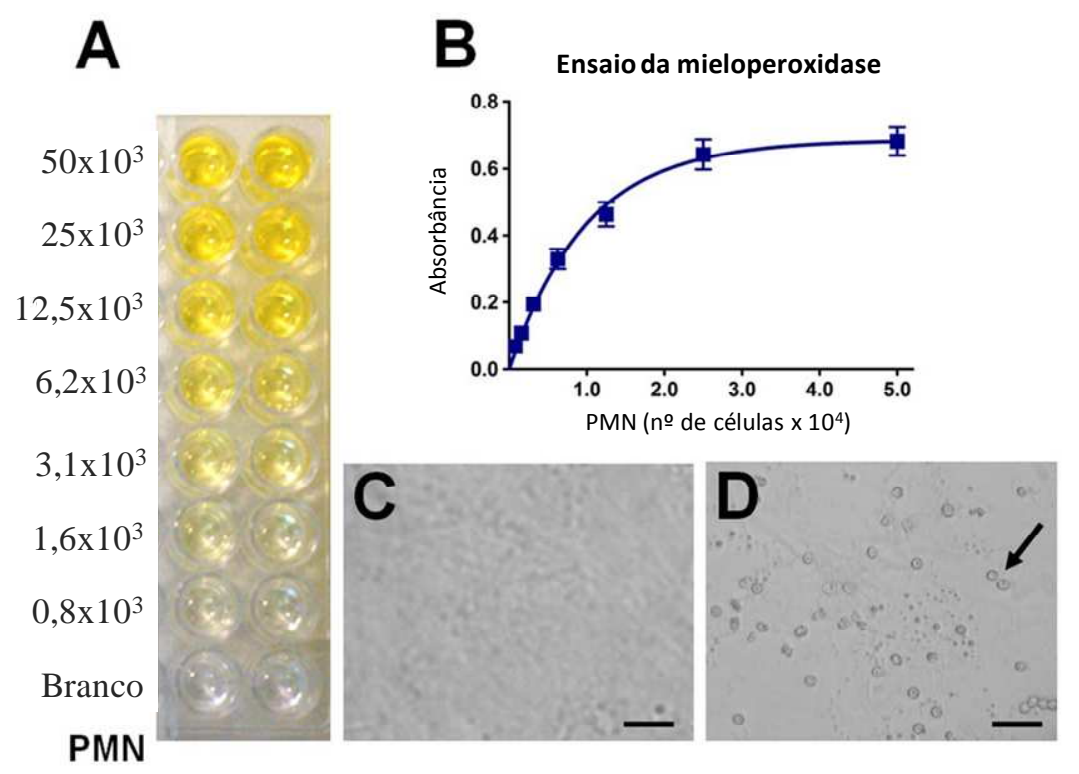

Figura 6 - Ensaio de adesão de neutrófilos in vitro. $\mathrm{O}$ número de neutrófilos aderidos às células endoteliais é determinado a partir da reação imunoenzimática da enzima mieloperoxidase presente nos neutrófilos. A quantificação é realizada por uma curva padrão de valores de neutrófilos conhecidos (A, B). Células endoteliais em confluência com (D) ou sem $(\mathrm{C})$ neutrófilos aderidos. Seta indica neutrófilo aderido à célula endotelial. Barra de escala $=50 \mu \mathrm{m}$ (adaptado de Tamura et al., 2010).

\section{Análise estatística}

Os dados estão apresentados como média \pm erro padrão da média (EPM) dos valores dependentes de cada condição experimental. A comparação entre dois grupos 
foi feita através do teste "t" de Student e a comparação de mais de dois grupos, por análise de variância ("one-way ANOVA") seguida pelo teste de Newman-Keuls. A análise de regressão linear foi realizada por análise de variância para determinação dos "slopes" (expressos como média \pm EPM) e a correlação foi feita pelo coeficiente de Pearson. A probabilidade de $5 \% \quad(\mathrm{p}<0,05)$ foi considerada como diferenças significativas entre os grupos. Toda a análise estatística foi feita por meio do software GraphPad Prism® versão 5.00 (GraphPad Software@). 


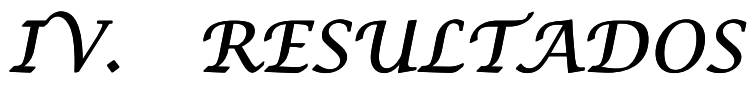

\section{TNF circulante}

O TNF, citocina produzida durante as primeiras horas da montagem de uma resposta inflamatória, reduz a produção de melatonina pela glândula pineal (Fernandes et al., 2006). Por outro lado, em modelos de sepse, melatonina inibe a produção de TNF induzida por LPS (Carrillo-Vico et al., 2005b). Constatamos que animais "naïve" ou aqueles injetados com veículo (salina $0,9 \%$ + etanol 5\%) não apresentaram TNF detectável no plasma. A administração de LPS $(0,5 \mathrm{mg} / \mathrm{kg})$ por duas horas induz o aumento de TNF circulante, que é reduzido pela administração concomitante de melatonina (3,0 mg/kg; figura 7). Nos animais tratados seis horas antes da morte, ainda é possível detectar TNF plasmático, no entanto, em concentrações aproximadamente 12 vezes menores. Neste momento, o efeito da melatonina sobre o LPS não é mais observado. 


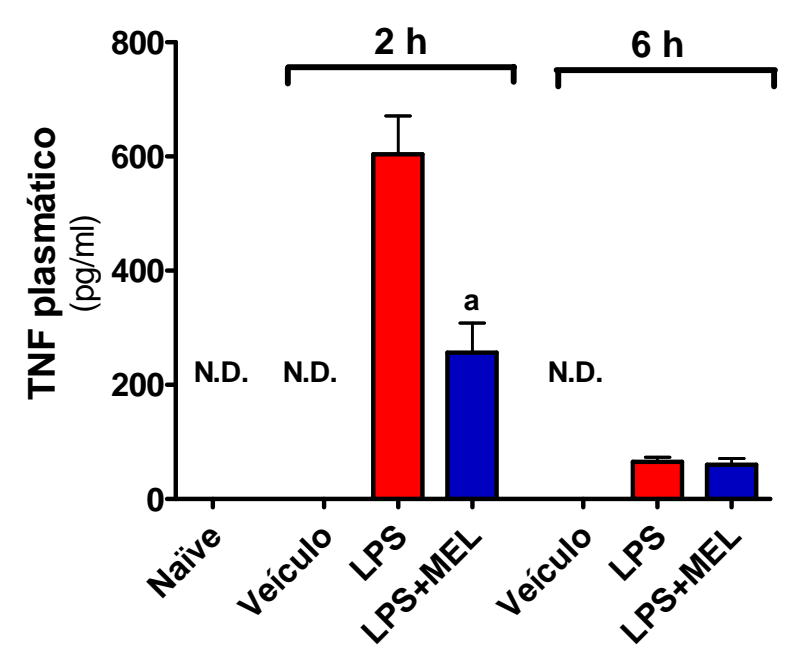

Figura 7 - Quantificação de TNF plasmático após tratamento com LPS. O plasma dos animais foi coletado no momento da morte (ZT18) após terem sido tratados $2 \mathrm{~h}$ ou $6 \mathrm{~h}$ antes com LPS $(0,5 \mathrm{mg} / \mathrm{kg})$ ou LPS + melatonina $(3,0 \mathrm{mg} / \mathrm{kg}$, LPS+MEL). Animais controles não receberam qualquer tratamento ("naïve") ou foram tratamentos com veículo (salina $0,9 \%$ + etanol 5\%). Nestes, a concentração plasmática de TNF não foi detectável (N.D.). A concentração plasmática de TNF foi determinada pela técnica de ELISA. Os dados estão apresentados como média \pm EPM. $\mathrm{n}=4$ a 8 animais por grupo, ${ }^{\mathrm{a}}$ significativamente diferente em relação ao grupo tratado com LPS $2 \mathrm{~h}$ antes da morte $(\mathrm{p}<0,05)$.

\section{LPS e a inibição do pico noturno de melatonina plasmática}

A teoria do eixo imune-pineal presume que o tratamento com LPS deve reduzir de forma transiente a produção de melatonina pela glândula pineal e com isto diminuir a concentração de melatonina no plasma. Desta forma, avaliamos o efeito da administração endovenosa de LPS realizado em ZT16 ou ZT12 sobre a concentração plasmática de melatonina e a transcrição do gene Aanat em pineais retiradas em ZT18. Desta forma, foi observado o efeito do LPS duas ou seis horas após a injeção. Considerando o pico de produção noturna de melatonina, a morte dos animais foi sempre realizada à noite em ZT18. 


\subsection{Efeito do LPS na inibição da melatonina produzida pela glândula} pineal

LPS $(0,5 \mathrm{mg} / \mathrm{kg})$ reduz significativamente a concentração de melatonina no plasma obtido em ZT18 quando comparado com o obtido de animais "naïve" ou injetados com veículo (figura 8A). Glândulas pineais retiradas dos mesmos animais foram usadas para avaliar o efeito de LPS sobre a enzima chave na síntese de melatonina, AA-NAT. Foi observada uma redução da transcrição gênica da Aa-nat, avaliada por RT-PCR em tempo real, em pineais retiradas de animais tratados com LPS, quando comparada com o grupo "naïve" ou veículo (figura 8B). Neste caso, foi observado que os animais injetados apenas com veículo apresentaram menor transcrição do gene Aanat que os animais "naïve". A redução simultânea da concentração plasmática de melatonina e da transcrição do gene Aa-nat sugere que LPS induz uma redução da síntese de melatonina pela glândula pineal.

O tratamento concomitante com LPS + melatonina $(3,0 \mathrm{mg} / \mathrm{kg})$ promoveu um aumento de cerca de seis vezes na melatonina circulante, sem modificar o efeito inibitório do LPS sobre a transcrição gênica (figura 8). 
A

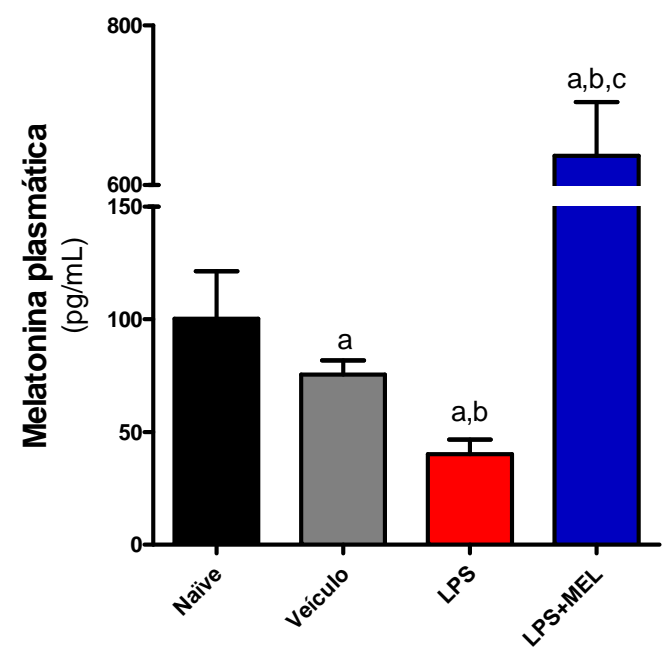

B

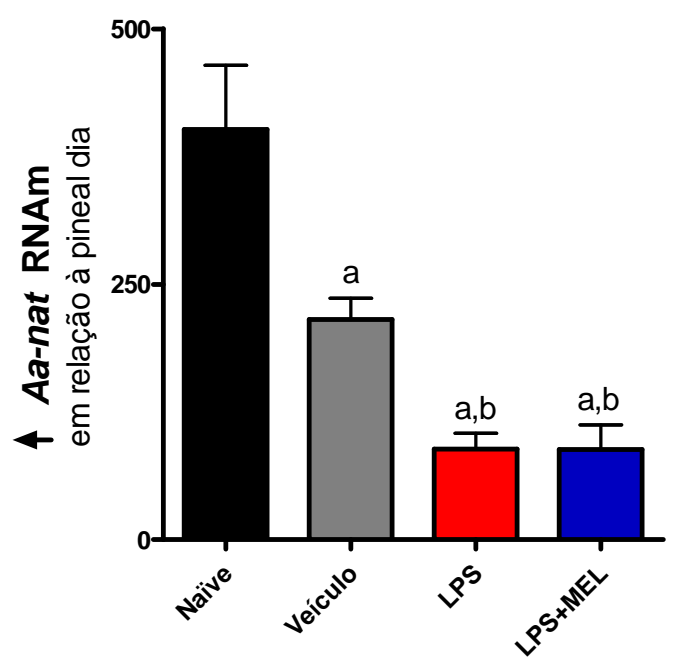

Figura 8 - Inibição da produção da melatonina noturna por LPS. (A) Avaliação da concentração plasmática de melatonina realizada por ELISA. O plasma dos animais foi coletado no momento da morte (ZT18) após duas horas (ZT16) de tratamento endovenoso com LPS $(0,5 \mathrm{mg} / \mathrm{kg})$ ou LPS + melatonina $(3,0 \mathrm{mg} / \mathrm{kg}$, LPS+MEL). Plasma de animais injetados com veículo (salina $0,9 \%$ + etanol 5\%) e de animais não tratados ("naïve") foram utilizados como controle. (B) As glândulas pineais dos mesmos animais foram coletadas para determinação da transcrição gênica da enzima AA-NAT por RT-PCR em tempo real. A transcrição gênica de cada grupo corresponde ao aumento no conteúdo de RNAm da Aa-nat em relação ao conteúdo obtido em glândulas pineais de animais mortos durante o dia, fase na qual esta atividade é mínima. Os dados estão apresentados como média \pm EPM. $n=4$ a 10 animais por grupo, ${ }^{a}$ estatisticamente diferente em relação aos animais "naïve" $(p<0,05)$, estatisticamente diferente em relação aos animais tratados com veículo $(p<0,05)$ e estatisticamente diferente em relação aos animais tratados com LPS $(\mathrm{p}<0,001)$.

A inibição da produção de melatonina noturna não ocorre quando os animais são tratados seis horas antes da morte (figura 9). Os animais injetados com LPS + melatonina ainda apresentaram concentrações plasmáticas de melatonina significativamente acima dos demais. No entanto, o aumento agora era apenas cerca de três vezes. Estes experimentos definiram os grupos experimentais a serem usados no decorrer deste trabalho, de forma a termos um grupo formado por animais injetados com 
LPS que estão no processo de montagem da resposta inflamatória (duas horas) e um segundo grupo em que esta fase já foi ultrapassada (seis horas).

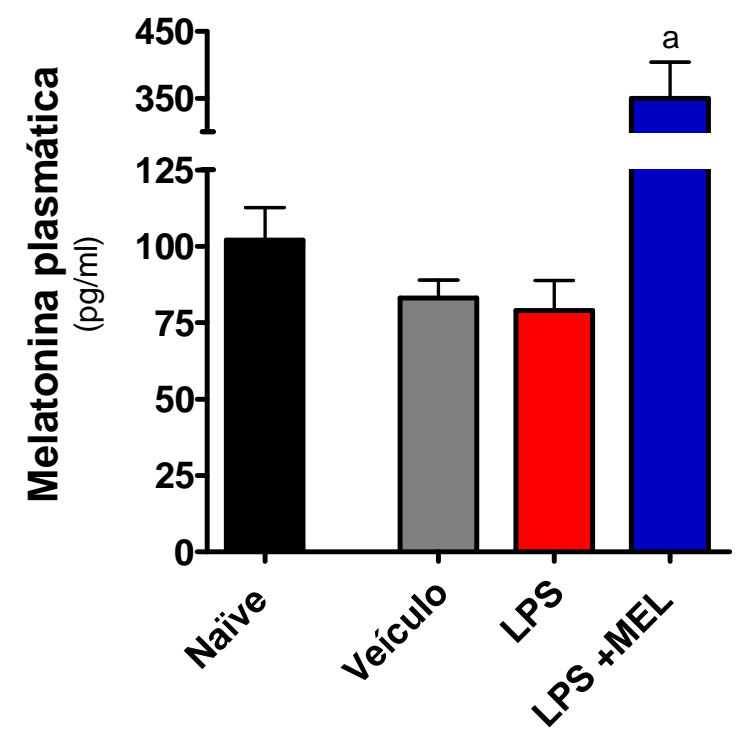

Figura 9 - Melatonina noturna após seis horas de tratamento com LPS. O plasma de animais tratados com LPS $(0,5 \mathrm{mg} / \mathrm{kg})$ ou LPS + melatonina $(3,0 \mathrm{mg} / \mathrm{kg}$, LPS+MEL) no ZT12 e mortos após seis horas do tratamento foram coletados para dosagem da concentração plasmática de melatonina por ELISA. Animais injetados com veículo (salina 0,9\% + etanol $5 \%)$ ou não tratados ("naïve") foram considerados como controles. Os dados estão apresentados como média \pm EPM. $\mathrm{n}=4$ a 10 animais por grupo, ${ }^{\mathrm{a}}$ estatisticamente diferente em relação aos demais grupos $(\mathrm{p}<0,001)$.

\section{Efeito ex-vivo do LPS sobre as células endoteliais}

Foram feitas culturas de células endoteliais obtidas de animais tratados ou não com LPS e mortos duas ou seis horas após o tratamento. Para avaliar o estado de ativação destas células em cultura foi avaliada a expressão de iNOS, ICAM-1 e PECAM-1 por técnica de imunofluorescência. Além disso, foi avaliada a funcionalidade destas células através de um ensaio de adesão de neutrófilos in vitro. 


\subsection{Ativação das células endoteliais após injeção de LPS}

Após 18 dias em cultura, células endoteliais obtidas de animais tratados com LPS em ZT16 e mortos após duas horas, apresentaram maior estado de ativação que células obtidas de animais injetados com veículo ou animais não tratados. A expressão de iNOS, ICAM-1 e PECAM-1 é maior em células retiradas de animais tratados com LPS quando comparada àquela de células obtidas de animais controle (figuras 10 e 11). Este efeito é revertido quando o tratamento com LPS é realizado seis horas antes da morte (figura 11). A injeção de melatonina juntamente com LPS duas horas antes da morte dos animais foi capaz de reduzir a expressão destas moléculas a níveis basais (figuras 10 e 11). 

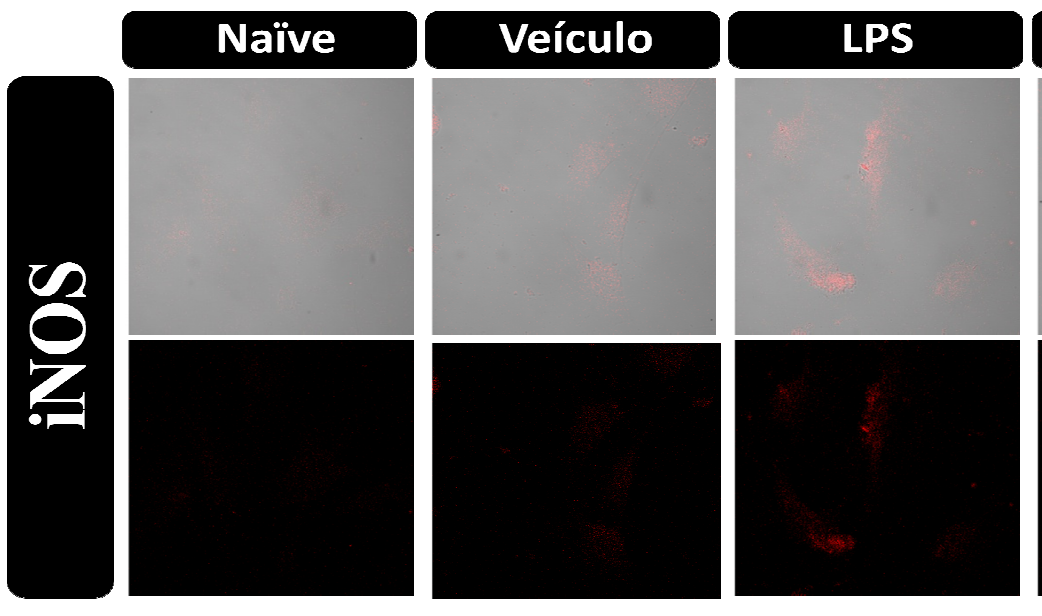

\section{LPS+MEL}
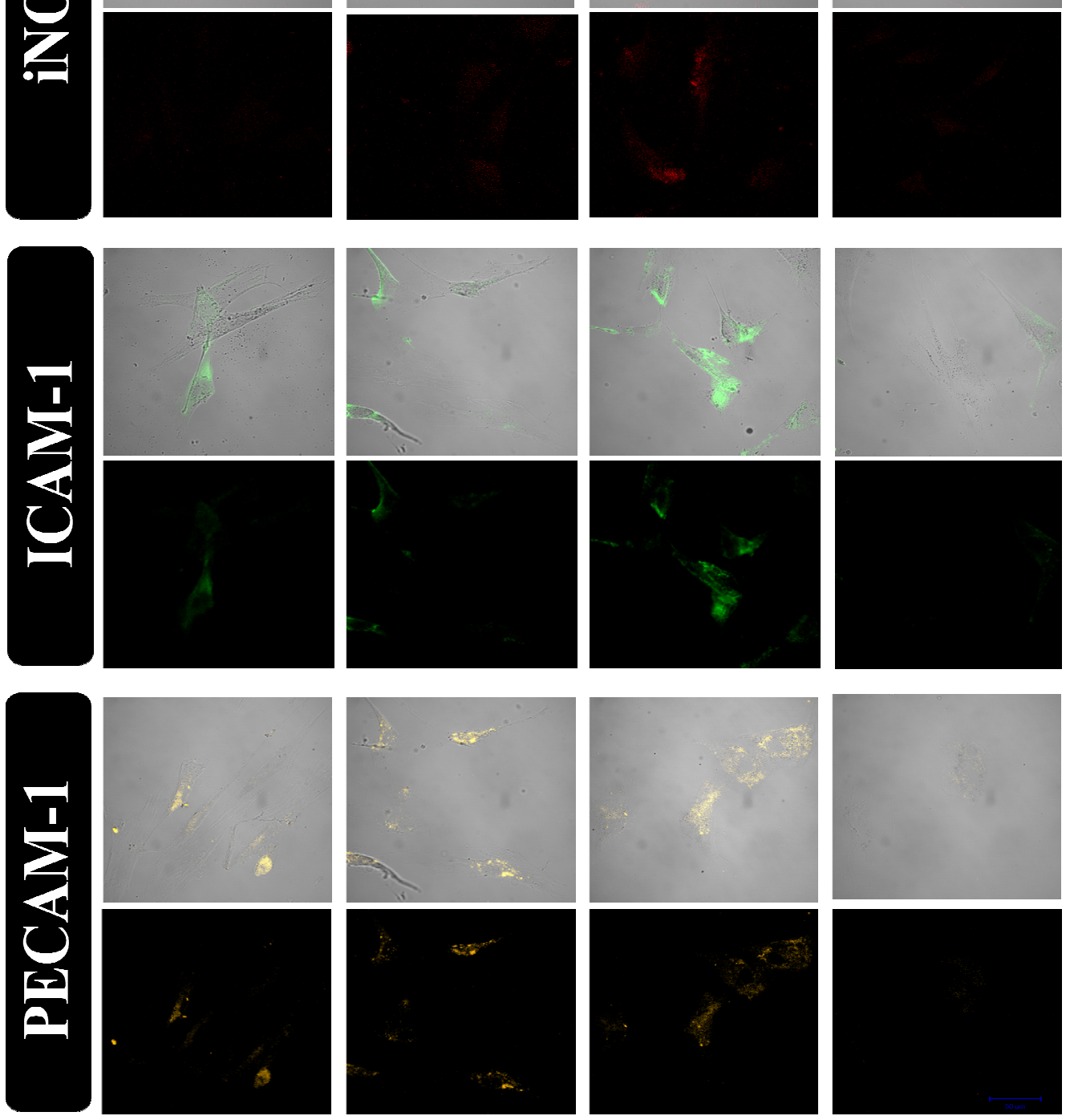

Figura 10 - Expressão da enzima iNOS e moléculas de adesão em células endoteliais após tratamento ex vivo com LPS. Reatividade de células endoteliais obtidas de animais tratados com LPS $(0,5 \mathrm{mg} / \mathrm{kg})$ ou LPS + melatonina $(3,0 \mathrm{mg} / \mathrm{kg}$, LPS $+\mathrm{MEL})$ e mortos à noite após duas horas do tratamento. A expressão de iNOS (anti-NOS2), ICAM-1 (anti-CD54) e PECAM-1 (anti-CD31) foi avaliada por imunofluorescência em microscopia confocal. Células obtidas de animais tratados com veículo (salina 0,9\% + etanol 5\%) ou animais não tratados ("naïve") foram consideradas controles. As imagens estão representadas com contraste de fase (fundo claro) ou apenas com a fluorescência emitida pelo marcador (fundo escuro) de um mesmo campo. Barra de escala: $50 \mu \mathrm{m}$. 
A

B

CAM-1

C
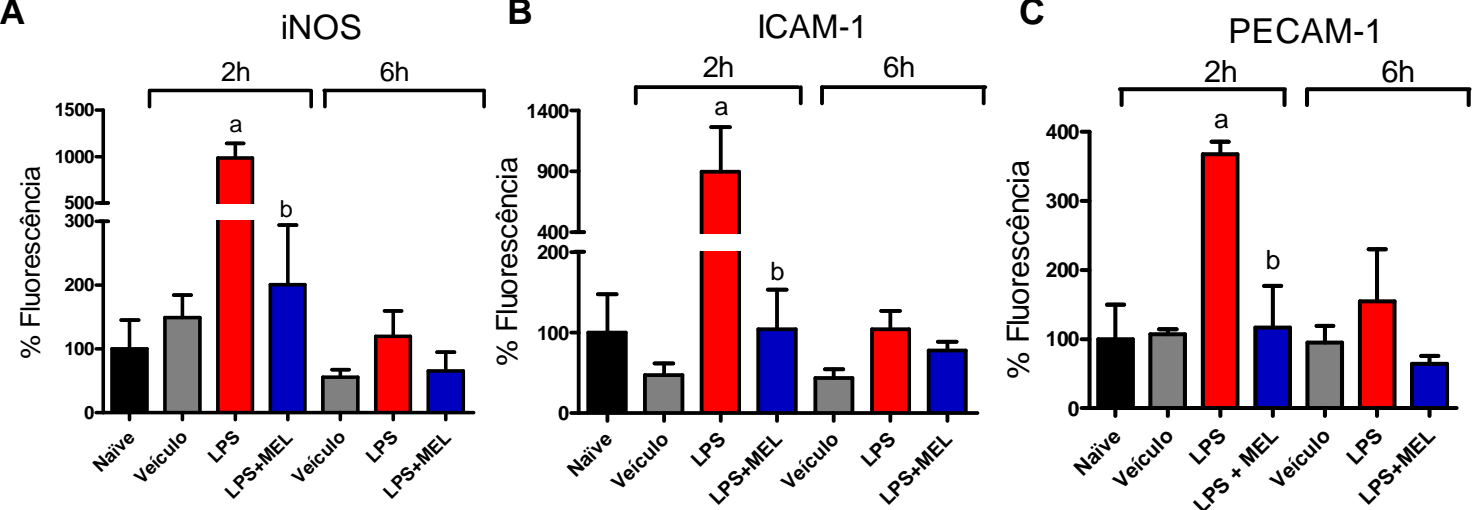

Figura 11 - Reatividade de células endoteliais obtidas de animais tratados com LPS. Células endoteliais mantidas em cultura até atingirem confluência foram obtidas do músculo cremaster de animais tratados com LPS $(0,5 \mathrm{mg} / \mathrm{kg})$ ou LPS + melatonina $(0,3 \mathrm{mg} / \mathrm{kg}$, LPS+MEL) $2 \mathrm{~h}$ ou $6 \mathrm{~h}$ antes da morte (ZT18.) Animais injetados com veículo (salina $0,9 \%+$ etanol 5\%) e animais não tratados ("naïve") foram considerados como controles. A expressão de iNOS (A), ICAM-1 (B) e PECAM-1 (C) foi analisada por imunofluorescência em microscopia confocal. Os dados estão normalizados em porcentagem em relação ao grupo "naïve" e apresentados como média \pm EPM. $\mathrm{n}=4$ a 5 animais por grupo, "estatisticamente diferente dos grupos veículo e "naïve" $(\mathrm{p}<0,05)$ e ${ }^{\mathrm{b}}$ estatisticamente diferente do grupo tratado com LPS $2 \mathrm{~h}$ antes da morte $(\mathrm{p}<0,05)$.

\subsection{Ensaio de adesão de neutrófilos in vitro}

Funcionalmente, células endoteliais obtidas de animais tratados com LPS duas horas antes da morte aderem mais neutrófilos que células obtidas de animais "naïve" ou injetados com veículo (figura 12). A injeção com melatonina reverteu o efeito induzido por LPS. Após seis horas de tratamento, a capacidade de adesão de neutrófilos não apresentou diferenças estatísticas entre os grupos (figura 12). 


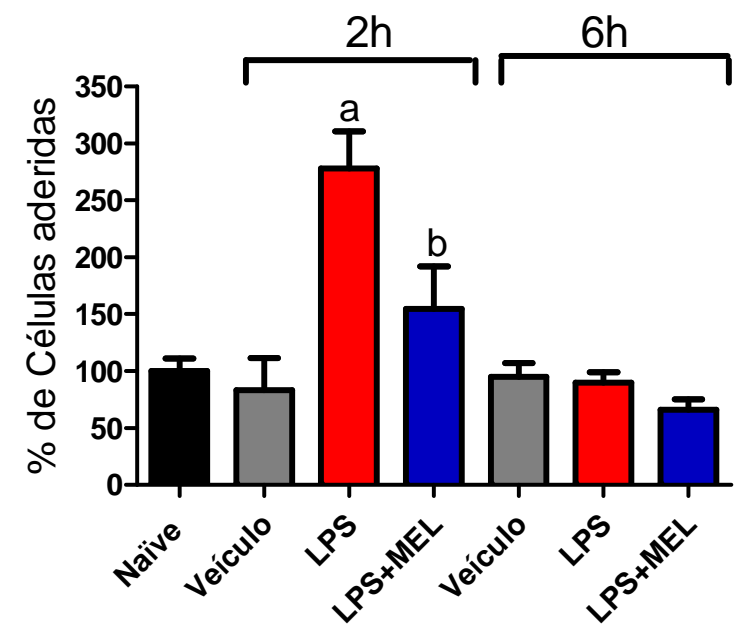

Figura 12 - Capacidade de adesão de neutrófilos de células endoteliais após tratamento com LPS. Células endoteliais foram obtidas do músculo cremaster de animais tratados com LPS $(0,5 \mathrm{mg} / \mathrm{kg}, \mathrm{ZT} 12$ - $6 \mathrm{~h}$ ou ZT16 - 2h) ou LPS + melatonina $(3,0 \mathrm{mg} / \mathrm{kg}$, LPS+MEL, ZT12 6h ou ZT16 - 2h) e mantidas em cultura até confluência. A capacidade de adesão de neutrófilos foi avaliada in vitro por ensaio colorimétrico da enzima mieloperoxidase e os resultados foram normalizados por porcentagem em relação ao grupo não tratado ("naïve"). Animais tratados com veículo (salina $0,9 \%+$ etanol 5\%) foram utilizados como controle experimental do tratamento. Os dados estão apresentados como média \pm EPM. $n=4$ animais por grupo, a estatisticamente diferente em relação ao grupo tratado com veículo ou "naïve" (p $<0,05)$, estatisticamente diferente em relação ao grupo tratado com LPS $2 \mathrm{~h}$ antes da morte $(\mathrm{p}<0,05)$.

\section{Efeito da hora do dia na reatividade de células endoteliais em}

\section{cultura}

Os dados acima apresentados demonstraram que a melatonina reduziu o efeito induzido por LPS. Como a melatonina é um hormônio presente em elevadas concentrações durante a fase de escuro, nosso próximo passo foi avaliar se as células endoteliais obtidas de animais não tratados e mortos de dia ou à noite apresentavam diferenças na sua reatividade. Para isso, utilizamos células endoteliais de animais mortos no ZT18, correlacionando com o pico de produção de melatonina, ou no ZT6. 
Dessa forma, criou-se protocolos experimentais nos quais animais foram mortos à noite ou de dia. Avaliamos a reatividade destas células por meio da expressão de iNOS, ICAM-1 e PECAM-1 por ensaios de imunofluorescência e ainda pelo ensaio funcional de adesão de neutrófilos.

\subsection{Estado de ativação das células endoteliais dependente da hora de obtenção}

A produção de melatonina atinge seu pico na fase de escuro, sendo aproximadamente 100 vezes maior do que os níveis observados durante a fase de claro. Conforme esperado, animais mortos durante a noite (ZT18) apresentaram maior concentração plasmática de melatonina do que animais mortos durante o dia (ZT6, noite $=110,1 \pm 8,41 \mathrm{pg} / \mathrm{ml}, \mathrm{dia}=29,5 \pm 5,46 \mathrm{pg} / \mathrm{ml} ; \mathrm{p}<0,001)$.

Após 16 dias em cultura, células endoteliais obtidas de animais mortos à noite estavam menos ativadas que células obtidas de animais mortos de dia. A expressão de iNOS, ICAM-1 e PECAM-1 foi maior em células obtidas no ZT6 que as obtidas no ZT18 (figuras 13 e 14). 


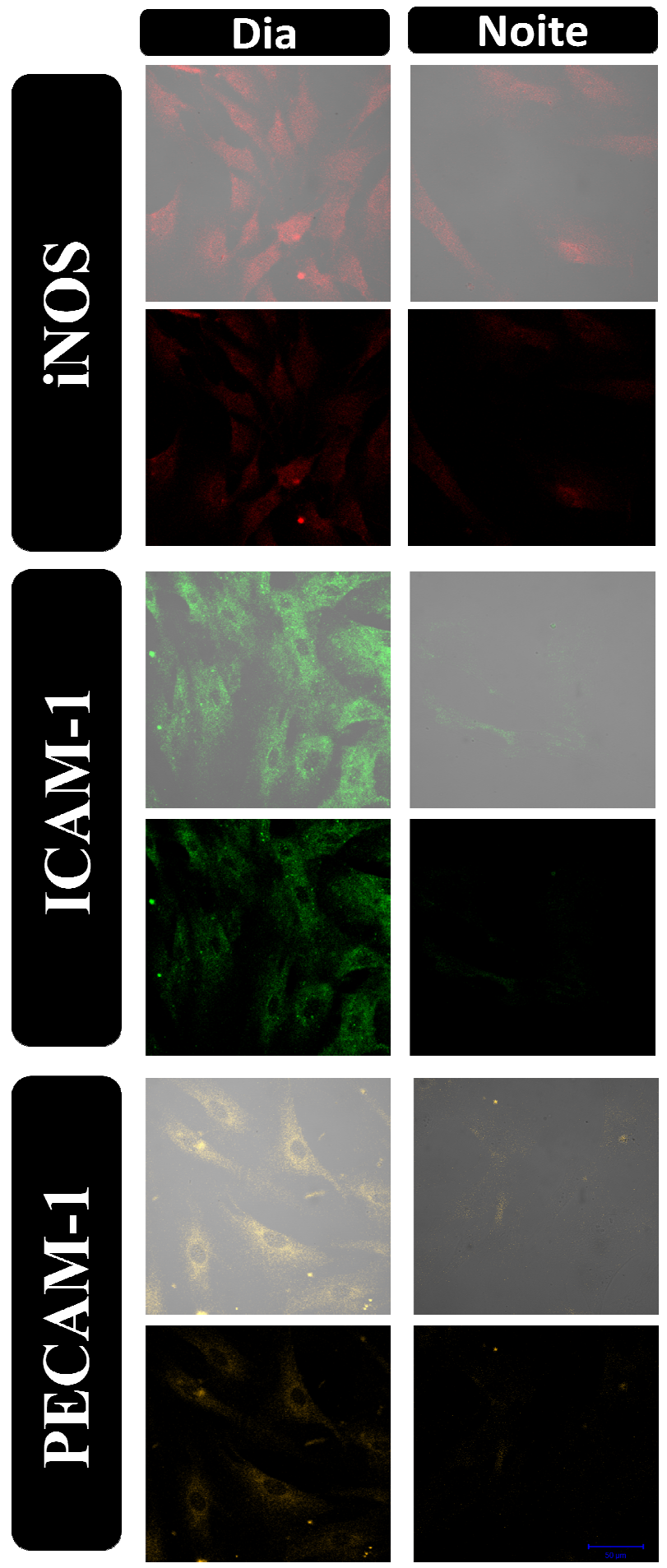

Figura 13 - Reatividade de células endoteliais obtidas em diferentes horários. Expressão de iNOS (anti-NOS2), ICAM-1 (anti-CD54) e PECAM-1 (anti-CD31) por imunofluorescência em microscopia confocal de células endoteliais obtidas de animais mortos durante o dia ou à noite. As imagens estão representadas com contraste de fase (fundo claro) ou apenas com a fluorescência emitida pelo marcador (fundo escuro) de um mesmo campo. Barra de escala: 50 $\mu \mathrm{m}$. 

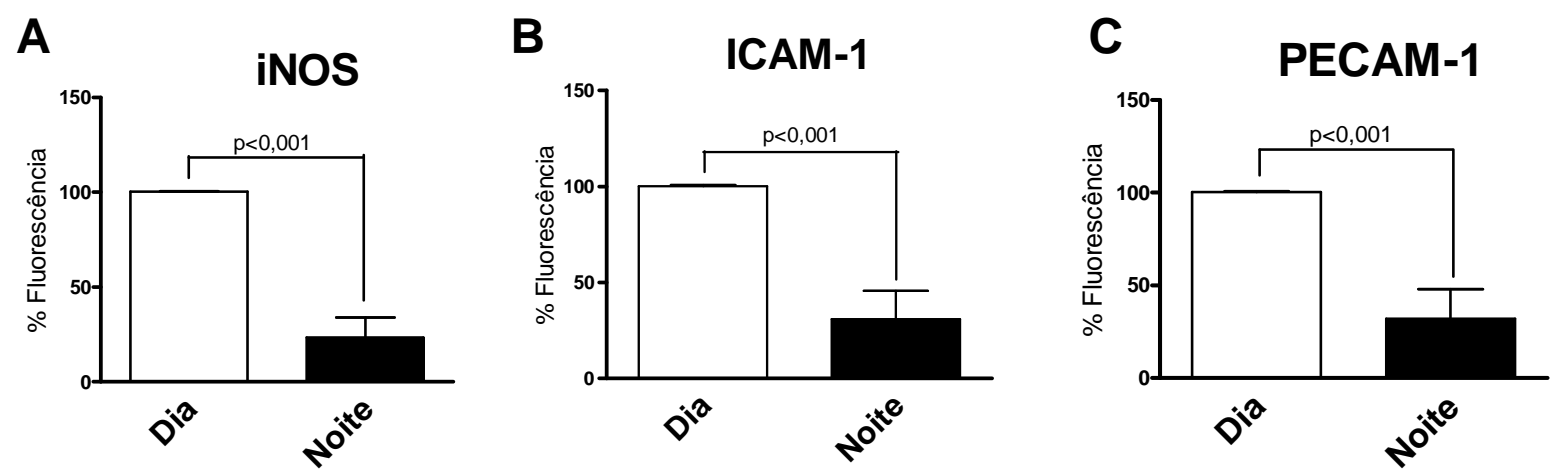

Figura 14 - Reatividade de células endoteliais dependente da hora do dia de obtenção. Células endoteliais foram obtidas do músculo cremaster de animais mortos durante a noite (ZT18) ou durante o dia (ZT6) e mantidas em cultura até confluência. A expressão de iNOS (A), ICAM-1 (B) e PECAM-1 (C) foi avaliada por imunofluorescência em microscopia confocal. Os dados são normalizados em porcentagem em relação aos animais mortos de dia e apresentados como média \pm EPM. $\mathrm{n}=4$ a 8 animais por grupo.

Ao avaliar funcionalmente a capacidade de adesão in vitro, as células obtidas durante a noite possuem menor capacidade de aderir neutrófilos que células obtidas de dia (figura 15), conforme a expressão de moléculas de adesão, sugerindo, novamente, que a menor capacidade de adesão das células obtidas à noite é decorrente da menor expressão de moléculas de adesão. 


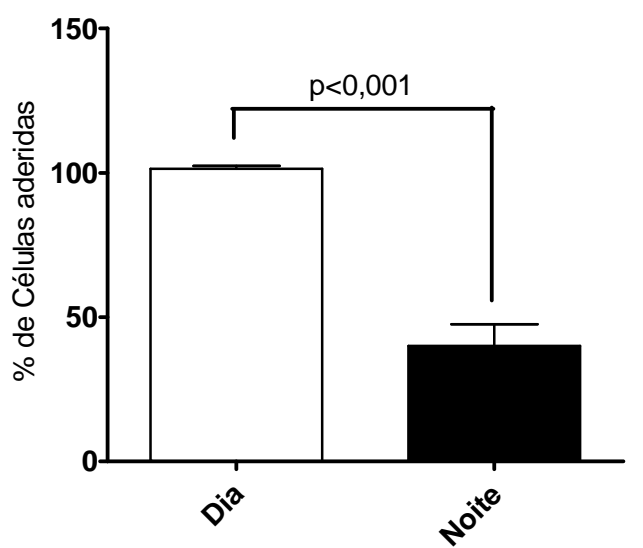

Figura 15 - Adesão de neutrófilos em células endoteliais obtidas em diferentes horários. Células endoteliais obtidas do músculo cremaster de animais mortos durante o dia ou à noite e mantidas em cultura até confluência foram replaqueadas para o ensaio de adesão de neutrófilos in vitro. Os dados são apresentados como média \pm EPM dos valores em porcentagem normalizados em relação ao grupo dia. $\mathrm{n}=5$ animais por grupo.

\section{Efeito do LPS durante o dia}

Visto que células endoteliais se encontram mais ativadas durante o dia quando comparadas com células obtidas durante a noite, avaliamos a reatividade destas células frente a um estímulo por LPS administrado durante o dia. Foi realizada a administração endovenosa de LPS $(0,5 \mathrm{mg} / \mathrm{kg})$ duas (ZT4) ou seis horas (ZT0) antes da morte, que foi realizada sempre no ZT6, correspondente a 12 horas de diferença do pico de produção noturna de melatonina. Para melhor visualização e comparação entre os resultados, colocaremos novamente os dados já apresentados acima, referente aos grupos experimentais tratados durante a noite.

\subsection{Avaliação da produção de TNF}

O tratamento com LPS duas horas (ZT4) antes da morte realizada durante o dia induziu um aumento plasmático de TNF em relação aos animais "naïve" ou tratados com veículo, os quais não apresentaram níveis detectáveis de TNF plasmático. Por 
outro lado, apesar de a melatonina mostrar uma tendência na redução do efeito do LPS, essa diferença não é estatisticamente significativa entre os animais tratados durante o dia com LPS + melatonina ou somente LPS (figura 16).

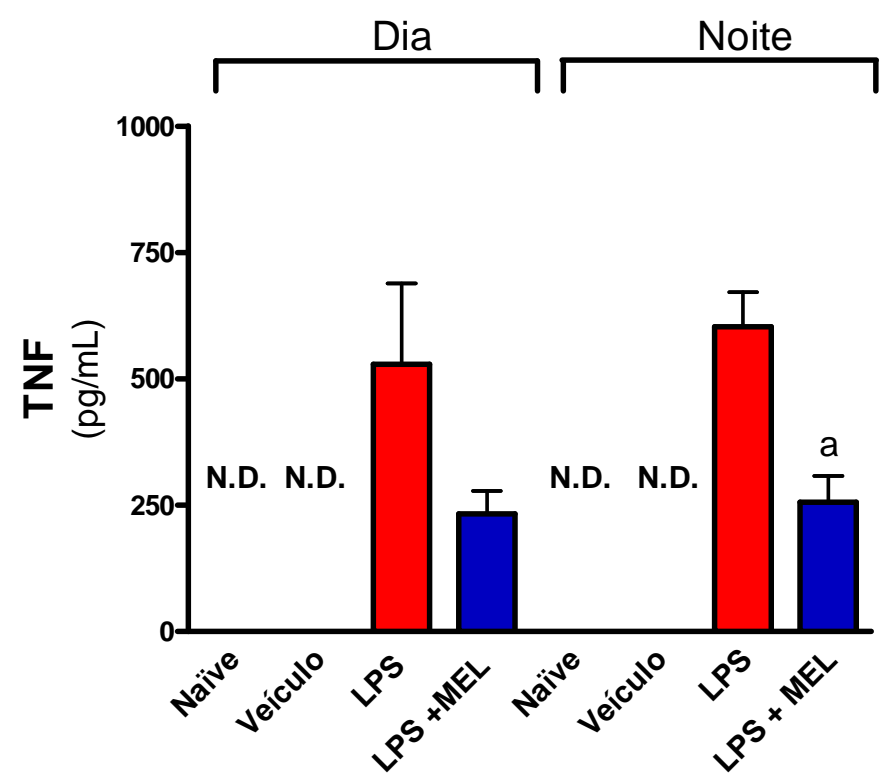

Figura 16 - Avaliação da concentração plasmática de TNF de acordo com o horário do estímulo. O plasma de animais tratados com LPS $(0,5 \mathrm{mg} / \mathrm{kg})$ ou LPS + melatonina $(3,0$ $\mathrm{mg} / \mathrm{kg}$, LPS+MEL) duas horas antes da morte (ZT6 - dia ou ZT18 - noite) foi coletado para análise do TNF plasmático por ELISA. Animais injetados com veículo (salina 0,9\% + etanol 5\%) ou não tratados ("naïve") não apresentaram níveis detectáveis (N.D.) de TNF. Os dados são apresentados como média \pm EPM. $n=4$ a 8 animais por grupo, ${ }^{a}$ estatisticamente diferente em relação aos animais tratados com LPS injetado à noite $(\mathrm{p}<0,05)$.

\subsection{Efeito ex-vivo do LPS sobre as células endoteliais obtidas de}

\section{animais mortos durante o dia}

Células endoteliais obtidas de animais tratados com LPS durante o dia estão mais ativadas que células obtidas de animais "naïve" ou tratados com veículo. Semelhante aos grupos que receberam tratamento durante a noite, a expressão de iNOS e moléculas de adesão é maior em células obtidas de animais tratados com LPS duas horas antes da morte (figuras 17 e 18 A, B e C). Da mesma forma, a capacidade de 
adesão de neutrófilos é maior em células provenientes de animais que receberam a injeção de LPS (figura 18 D). A melatonina reverteu o efeito do LPS quando administrado durante o dia (figuras 17 e 18). Juntamente, os dados obtidos pelo tratamento de LPS durante o dia ou durante a noite sugerem que a montagem do processo inflamatório é iniciada independente da hora do dia em que o estímulo é dado, e que o efeito do tratamento com melatonina também não depende deste fator.

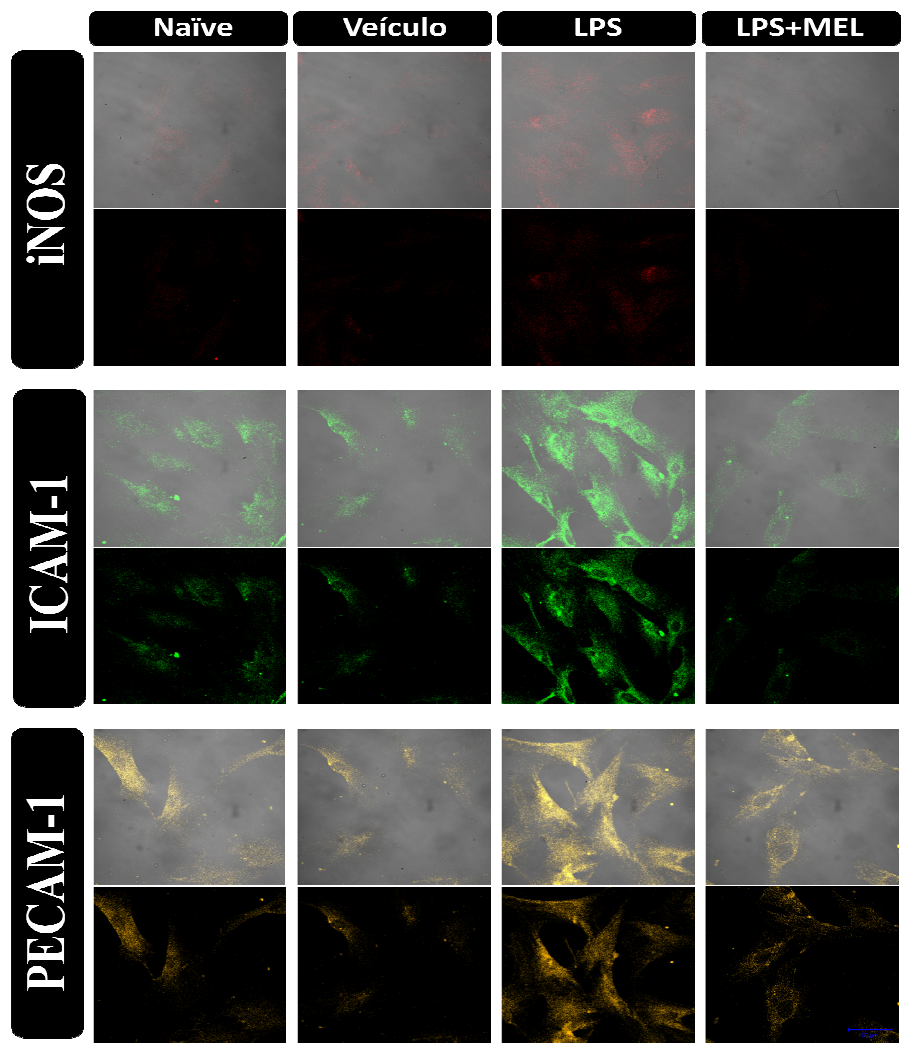

Figura 17 - Expressão da enzima iNOS e moléculas de adesão de células endoteliais obtidas de animais tratados com LPS durante o dia. Reatividade de células endoteliais obtidas de animais tratados com LPS $(0,5 \mathrm{mg} / \mathrm{kg})$ ou LPS + melatonina $(3,0 \mathrm{mg} / \mathrm{kg}$, LPS+MEL) duas horas antes da morte realizada durante o dia (ZT6). A expressão de iNOS (anti-NOS2), ICAM-1 (anti-CD54) e PECAM-1 (anti-CD31) foi avaliada por imunofluorescência em microscopia confocal. Células obtidas de animais tratados com veículo (salina 0,9\% + etanol $5 \%$ ) e de animais não tratados ("naïve") foram consideradas como controle. As imagens estão representadas com contraste de fase (fundo claro) ou apenas com a fluorescência emitida pelo marcador (fundo escuro) de um mesmo campo. Barra de escala: $50 \mu \mathrm{m}$. 
A

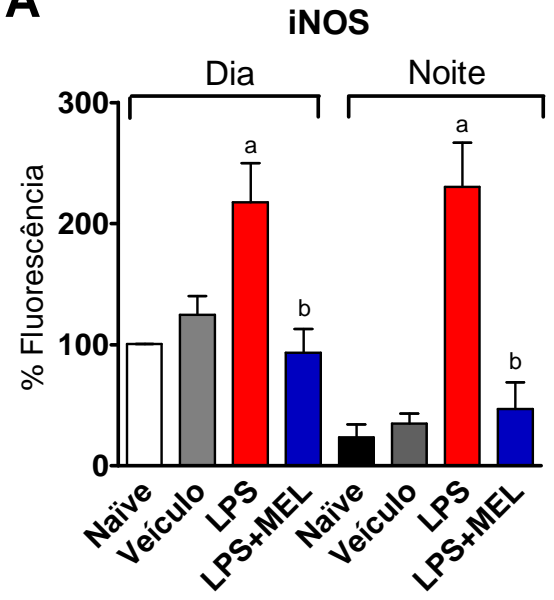

C

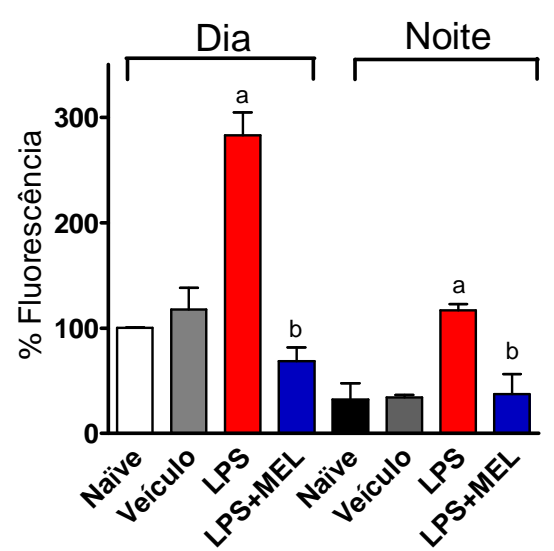

B ICAM-1

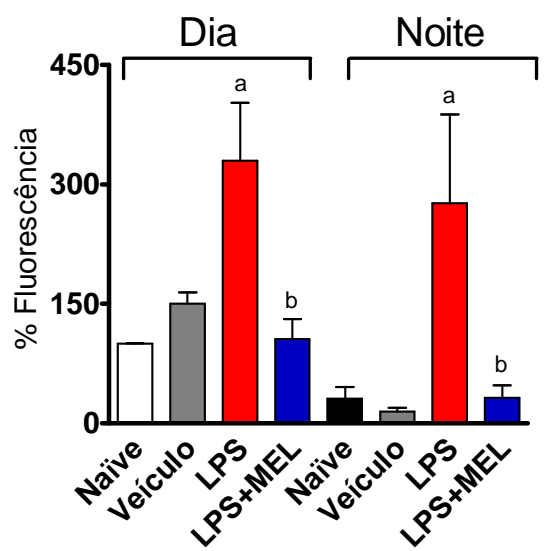

D

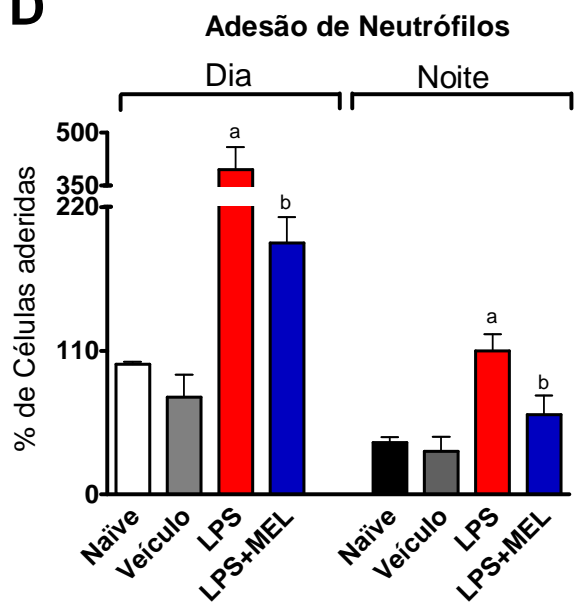

Figura 18 - Efeito do LPS sobre a reatividade de células endoteliais de acordo com a hora de administração. Células endoteliais foram obtidas de animais tratados com LPS $(0,5 \mathrm{mg} / \mathrm{kg})$ ou LPS + melatonina $(3,0 \mathrm{mg} / \mathrm{kg}$, LPS+MEL) duas horas antes da morte (ZT6 - dia ou ZT18 noite). A expressão de iNOS (A), ICAM-1 (B) e PECAM-1 (C) foi analisada por imunofluorescência em microscopia confocal e a capacidade de adesão de neutrófilos (D) realizada in vitro por ensaio colorimétrico da enzima mieloperoxidase. Animais tratados com veículo (salina $0,9 \%$ + etanol $5 \%$ ) e animais não tratados ("naïve") foram considerados como controles. Os dados estão apresentados como média \pm EPM dos valores em porcentagem normalizados em relação ao grupo "naïve-dia". " estatisticamente diferente em relação ao grupo tratado com veículo e "naïve" $\mathrm{e}$ b estatisticamente diferente em relação aos animais tratados com LPS, referentes ao mesmo horário de tratamento $(\mathrm{p}<0,05)$. 
Comparando quantitativamente o tratamento de LPS realizado nos ZT4 e ZT16, observamos que o aumento das expressões de iNOS e ICAM-1 foi semelhante entre os diferentes horários de tratamento (figura 18 A e B). No entanto, proporcionalmente, este aumento é maior nas células obtidas de animais tratados à noite do que de dia, já que os níveis basais de expressão dessas moléculas à noite são menores. Assim sendo, o efeito proporcional de inibição do LPS decorrente do tratamento com melatonina é maior quando realizado à noite (figura $18 \mathrm{~A}$ e B). Por outro lado, quando analisamos a expressão de PECAM-1 e a adesão de neutrófilos, células obtidas de animais tratados com LPS à noite expressaram menor quantidade de PECAM-1 e aderiram menos neutrófilos que células obtidas de animais tratados com LPS durante o dia (figura $18 \mathrm{C} \mathrm{e}$ D).

O estado de ativação de células endoteliais obtidas de animais tratados durante o dia com LPS seis horas antes da morte não apresentou diferenças estatísticas em relação aos animais "naïve" ou injetados com veículo (figura 19). 
A

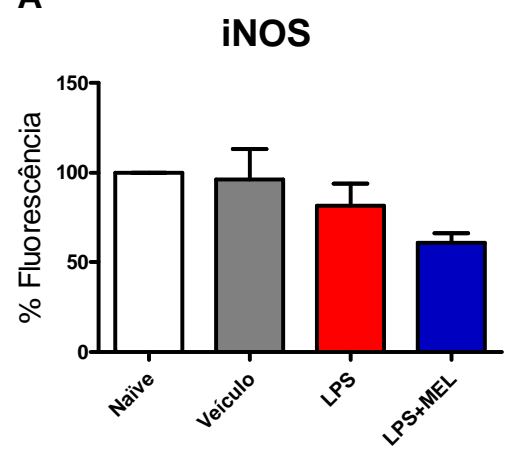

C

PECAM-1

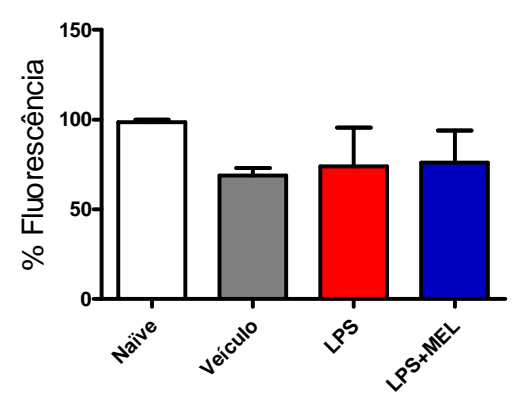

B

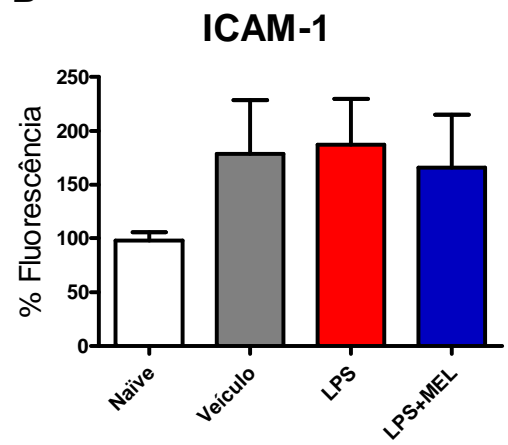

D

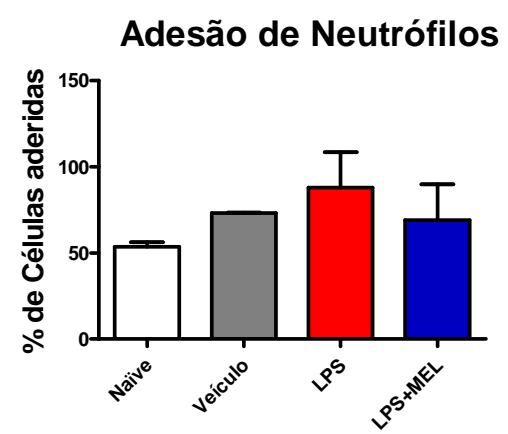

Figura 19 - Reatividade de células endoteliais após seis horas de tratamento com LPS. Avaliação da reatividade de células endoteliais obtidas de animais tratados com LPS (0,5 $\mathrm{mg} / \mathrm{kg})$ ou LPS + melatonina $(3,0 \mathrm{mg} / \mathrm{kg}$, LPS+MEL) seis horas antes da morte (ZT6). A expressão de iNOS (A), ICAM-1 (B) e PECAM-1 (C), determinada por imunofluorescência em microscopia confocal, e a capacidade de adesão de neutrófilos não apresentam diferenças significativas entre os grupos experimentais e o grupo controle (veículo). Os dados são apresentados como média \pm EPM dos valores em porcentagem normalizados em relação ao grupo de animais que não receberam nenhum tratamento ("naïve"). $\mathrm{n}=3$ a 4 animais por grupo.

\section{Células endoteliais são primadas pela concentração}

\section{plasmática de melatonina}

Os dados anteriores, de uma forma geral, sugerem que a concentração de melatonina plasmática na hora em que os animais foram mortos prima as células endoteliais conferindo as mesmas capacidades de adesão de neutrófilos e expressão de moléculas de adesão que são mantidas por vários dias e gerações em cultura. Para 
avaliar esta hipótese levantada a partir de nossos dados experimentais, passamos a avaliar a correlação entre expressão das moléculas de adesão (ICAM-1 e PECAM-1) e da enzima iNOS com a concentração plasmática de melatonina na hora da morte dos animais. Para compor a figura 20 usamos todos os dados experimentais obtidos de animais mortos à noite independente dos grupos, apenas considerando a correlação de iNOS, ICAM-1 e PECAM-1 com a melatonina plasmática, animal por animal.

Quando há elevadas concentrações de melatonina plasmática, a atividade das células endoteliais é menor (figura 20). Esta nova forma de analisar os dados reforça que as células endoteliais têm uma memória celular que preserva as informações decorrentes dos níveis plasmáticos de melatonina.

A

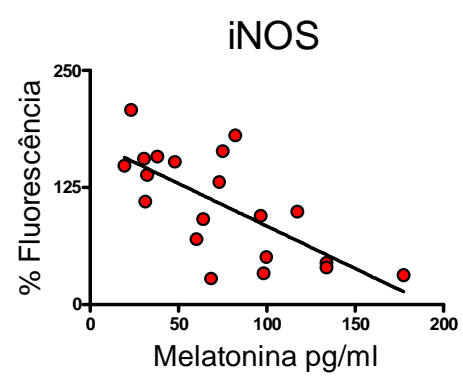

B

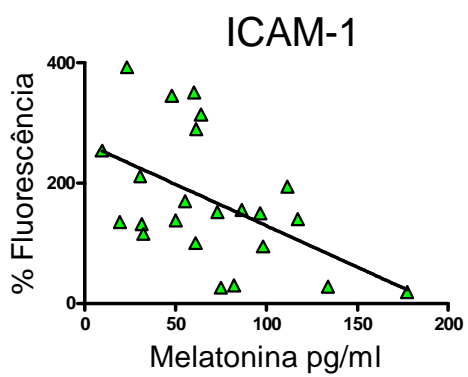

C

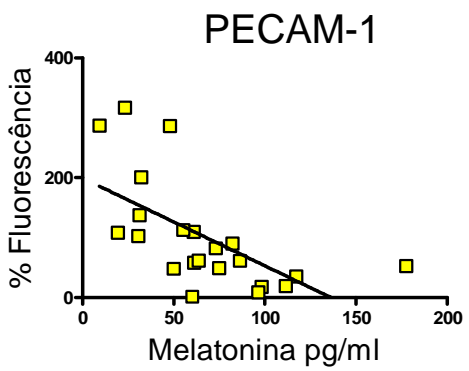

Figura 20 - Correlação entre a concentração plasmática de melatonina e a atividade de células endoteliais. A concentração plasmática de melatonina é inversamente correlacionada com a expressão de iNOS (A), ICAM-1 (B) e PECAM-1 (C) analisada por imunofluorescência. Para obtenção desses resultados, foi comparado animal por animal independente do grupo experimental ao qual pertence, considerando, portanto, apenas a concentração de melatonina no plasma com o efeito observado nas células endoteliais. Os resultados são apresentados de acordo com o coeficiente de Pearson (Pearson's $r=-0,692,-0,477$ e - $-0,189$; limite de confiança $=-0,869$ a $0,360,-0,754$ a $-0,057$ e $-0,763$ a $-0,146 ; p=0,0007,0,029$ e 0,009, sempre nesta ordem: iNOS, ICAM-1 e PECAM-1). 


\section{V. $\quad$ DISCUSS $\tilde{A} O$}

Por constituírem a interface entre a corrente sanguínea e o tecido adjacente e participarem da regulação do tônus vascular e da resposta inflamatória, as células endoteliais são alvos de diversos estudos. Dependendo das condições em que o organismo se encontra, a camada endotelial pode estar ativada ou em repouso. Frente a um estímulo inflamatório, as células endoteliais são ativadas a fim de responderem prontamente, apresentando maior capacidade de adesão de leucócitos que células em estado quiescente (para revisão, Michelis, 2003). Estudos em terapia celular encontram dificuldades devido à heterogeneidade de culturas celulares, sobretudo em relação aos parâmetros de estado de ativação (para revisão, Aird, 2007). Além disso, o uso de células em estado mais ativado pode ser prejudicial em procedimentos de terapia celular e transplantes. Este trabalho busca melhor compreender a reatividade de células endoteliais, uma vez que estas se fazem importantes para a compreensão de diversos processos patológicos. Os dados apresentados nesta dissertação apontam que células endoteliais possuem uma espécie de memória celular do momento em que foram coletadas, armazenando as informações por gerações.

Devido à sua localização privilegiada, o endotélio reconhece quaisquer alterações na composição sanguínea. Esta capacidade permite que as células endoteliais respondam a uma série de estímulos de forma mais apropriada. Sendo assim, essas alterações poderiam ser responsáveis pela mudança na reatividade destas células. Este trabalho demonstra o efeito ex vivo do LPS sobre a ativação de células endoteliais e a capacidade da melatonina em revertê-lo. Além disso, caracteriza a reatividade destas células de acordo com o horário em que são obtidas. Juntamente nossos dados colocam as células endoteliais no contexto do eixo imune-pineal. 
Segundo a nossa hipótese de trabalho, a comunicação bidirecional entre a glândula pineal e elementos imunocompetentes ativados durante a montagem de uma resposta inflamatória é a base para a existência de um eixo imune-pineal (para revisão, Markus et al., 2007). Resumidamente, a melatonina produzida ritmicamente pela pineal age sobre as células endoteliais diminuindo a migração de células imunológicas para o tecido adjacente. Frente a uma inflamação, a produção de melatonina noturna é inibida, permitindo a montagem de uma resposta inflamatória, na qual a capacidade de adesão e migração de células imunológicas para o local lesionado é aumentada. Em uma terceira fase, a produção de melatonina é restabelecida e a resposta inflamatória, solucionada (para revisão, Markus et al., 2007). Corroborando com esta hipótese, na presente dissertação, demonstramos como o tratamento endovenoso com LPS modula temporalmente a concentração plasmática de melatonina e a reatividade de células endoteliais.

Demonstramos que após administração sistêmica de LPS ocorre uma inibição da transcrição gênica da enzima AANAT e a redução da concentração noturna de melatonina no plasma. Estes efeitos podem ser decorrentes da sinalização desencadeada pelo LPS na pineal, uma vez que esta está equipada para reconhecer componentes bacterianos, como o LPS, pois expressam receptores "toll-like" do subtipo 4 (TLR-4, da Silveira Cruz-Machado et al., 2010). Validando a resposta dos animais ao LPS, observamos um aumento da concentração plasmática de TNF. Uma vez que a glândula pineal também expressa receptores para esta citocina (da Silveira Cruz-Machado et al., 2010) e que TNF inibe a transcrição gênica da enzima AA-NAT e a produção de NAS em glândulas pineais em cultura (Fernandes et al., 2006), é possível que não somente o LPS per se atue na glândula pineal, mas que outros mediadores inflamatórios endógenos também possam ser capazes de inibir a síntese noturna de melatonina. 
A montagem de uma resposta inflamatória é orquestrada por uma cinética de produção de mediadores pró e anti-inflamatórios, de modo a solucionar o quadro inflamatório preservando a integridade do tecido. O tratamento com LPS leva a um aumento transiente da concentração plasmática de TNF, que aumenta nas primeiras duas horas e decai após seis horas. Um decurso temporal semelhante, com o pico de TNF plasmático ocorrendo uma hora após a administração de LPS e um retorno a níveis basais quatro horas após, foi relatado por Kakizaki e colaboradores (1999) ao injetar este produto bacteriano pelas vias endovenosa e intraperitoneal. Considerando a cinética de produção de TNF e o efeito de LPS e TNF em glândulas pineais em cultura (Fernandes et al., 2006; da Silveira Cruz-Machado et al., 2010), concluímos que a injeção de LPS diminui a produção noturna de melatonina também in vivo.

Em resumo, no nosso modelo experimental, no início da resposta inflamatória gerada por administração de LPS ocorre um pico transiente de TNF plasmático e uma redução da produção de melatonina. Para testar se o pico de TNF em ratos inflamados à noite é também um fenômeno que requer a supressão da produção noturna de melatonina, avaliamos se a administração noturna de melatonina em animais injetados com LPS poderia reduzir o pico plasmático de TNF. Nestes experimentos utilizamos uma concentração de melatonina de $3,0 \mathrm{mg} / \mathrm{Kg}$ (i.v.), que vem sendo bastante utilizada por outros autores (Hotta et al., 2000; Wu et al., 2001, 2008; Bruck et al., 2004; Miyamoto, 2006). Chamamos a atenção que a concentração plasmática resultante é cerca de 6 vezes superior que a concentração plasmática máxima observada em ratos que não foram tratados ou que receberam a injeção com veículo.

Nos nossos experimentos verificamos que melatonina reduz a concentração plasmática de TNF induzida por LPS injetado endovenosamente. No entanto, vale ressaltar que o grupo do Prof. Guerrero da Universidade de Sevilha na Espanha, ao 
estudar o efeito da melatonina sobre a produção de TNF induzida por LPS injetado intraperitonealmente, observou apenas uma redução da concentração de TNF no peritônio, mas não na concentração plasmática (Carrillo-Vico et al., 2005b). Estes dados, aparentemente controversos, precisam ser analisados à luz da via de administração e do alto coeficiente de partição óleo-água da melatonina (Shida et al., 1994). Desta forma, é muito difícil prever qual a concentração de melatonina que atinge a corrente sanguínea após a administração intraperitoneal, visto que pode haver perdas importantes no tecido adiposo.

Considerando que as células endoteliais são alvo privilegiado do eixo imunepineal, e que culturas de células endoteliais aderem mais neutrófilos quando estimuladas com leucotrieno $\mathrm{B}_{4}$ (Lotufo et al., 2006) ou interleucina $1 \beta$ (IL-1 $\beta$, Isenberg, 2003) e aumentam a expressão de iNOS frente a estímulo por LPS (Heba et al., 2001; Tamura et al., 2009), neste trabalho avaliamos se o tratamento dos animais doadores pode resultar em cultura de células endoteliais em diferentes estados de ativação. Foi interessante observar que mesmo após 18 ou 20 dias em cultura, células obtidas de animais tratados com LPS mantêm maior capacidade de adesão de neutrófilos do que as obtidas de animais controle. Esse aumento na capacidade de adesão foi acompanhado por um aumento na expressão de moléculas de adesão. Vale ainda ressaltar que células endoteliais estão equipadas para responder ao estímulo de LPS e TNF, visto que expressam receptores TLR4 e TNFR (para revisão, Liu \& Kubes, 2003, Dauphinee \& Karsan, 2006).

O aumento da expressão de iNOS por células endoteliais pode participar no esforço para eliminar o patógeno (Moncada et al., 1997), em vista da citotoxicidade do NO. Ainda, também é preciso considerar que NO induz uma vasodilatação local que leva a uma redução do fluxo sanguíneo, facilitando a migração de neutrófilos (para 
revisão, Pober \& Sessa, 2007). Demonstramos que o tratamento do animal com LPS resulta em cultura de células endoteliais ativadas no sentido de aumentar a capacidade de adesão de leucócitos e produzir mediadores importantes para uma resposta inflamatória, como o NO e moléculas de adesão. Outro ponto relevante, é que estas respostas apresentam decurso temporal apropriado para realizar o ciclo completo, desde o combate ao agente agressor até a volta ao estado basal.

Como a produção de TNF, o aumento da expressão de iNOS e moléculas de adesão também foi transiente, visto que apenas foi observado em células obtidas de animais tratados duas horas, e não seis horas, antes da morte. Ao contrário do observado em nosso trabalho, células endoteliais do cordão umbilical humano (HUVEC) tratadas com LPS in vitro, aderem mais neutrófilos de quatro a seis horas após o estímulo, permanecendo ativadas por mais de 24 horas (Pohlman et al., 1986). Essas diferenças devem ser atribuídas ao fato de a cinética da resposta inflamatória gerada in vivo ser dependente de um conjunto de ações de mediadores produzidos não apenas por células endoteliais, mas também por células imunocompetentes, que em conjunto, regulam sistemicamente a resposta inflamatória.

A montagem de uma resposta inflamatória induzida por LPS ocorre a qualquer hora do dia. LPS induz a produção de TNF e a ativação de células endoteliais quando o tratamento é realizado tanto de dia quanto de noite. No entanto, observamos peculiaridades da resposta que dependem da iluminação ambiental. Se avaliarmos quantitativamente, a expressão de PECAM-1 e a adesão de neutrófilos são menores em células endoteliais provenientes de animais inflamados à noite, fato não observado com a expressão de ICAM-1 e iNOS. Isso deve ser decorrente da capacidade de LPS em reduzir a produção de melatonina pela glândula pineal. Nas nossas condições experimentais, observamos uma redução da ordem de $50 \%$ da produção noturna de 
melatonina, sugerindo que a modulação da expressão das diferentes proteínas que fazem parte do pacote da resposta inflamatória é regulada de forma diferente por esta indolamina. Assim, é possível que os mecanismos de ação da melatonina na modulação da expressão de PECAM-1 e outras moléculas devem ser diferentes dos mecanismos que regulam a expressão de ICAM-1 e iNOS. Corroborando com esta hipótese, a revisão de Woodfin e colaboradores (2007) mostra que a expressão de PECAM-1 na membrana celular de células endoteliais ocorre em maior quantidade nas regiões de junções entre as células, participando mais efetivamente do processo de migração dos leucócitos. Além disso, essa molécula é concentrada em vesículas que se reciclam por toda borda celular. A cinética de formação dessa vesícula e de exposição da PECAM-1 na superfície da membrana é modulada pelo aumento das concentrações intracelulares de $\mathrm{Ca}^{2+}$, que pode ser regulada, entre outros, pela ativação de ICAM-1 (para revisão, Lawson \& Wolf, 2009). Já a expressão de ICAM-1 ocorre em maior quantidade na superfície apical da célula, garantindo uma firme adesão de leucócitos. A transcrição gênica da ICAM-1 é iniciada por ativação do fator de transcrição NFKB e, em alguns casos, do fator AP-1, os quais podem ser ativados por estímulos inflamatórios, como LPS e TNF (para revisão, Rahman \& Fazal, 2009).

Melatonina administrada em conjunto com LPS impede o desencadeamento de efeitos característicos da reposta inflamatória, tais como aumento da expressão de iNOS, de moléculas de adesão e da adesão de neutrófilos à células endoteliais. Esta ação é base para um efeito citoprotetor. Tan e colaboradores (2010), em um trabalho de revisão recente, trazem que esta propriedade de defesa está presente desde grupos filogenéticos mais primitivos. Vale ressaltar que a grande maioria dos estudos sobre melatonina focou em seus efeitos cronobióticos (para revisão, Simmoneux \& Ribelayga, 2003), e apenas na última década surge um grande número de trabalhos mostrando que 
a melatonina é um mediador da resposta inflamatória e um agente antioxidante (para revisão, Carrillo-Vico et al, 2005a; Markus et al., 2007, 2010; Luchetti et al., 2011). Desse modo, a melatonina, atualmente, além de ser considerada o hormônio do escuro, também é reconhecida como uma participante importante das respostas de defesa do organismo.

A privação de melatonina ocasionada pela manutenção em luz constante provocou a diminuição da produção de peptídeos tímicos e o aumento de catecolaminas (Molinero et al., 2000), enquanto que o tratamento com propranolol em camundongos diminuiu a produção de anticorpos induzida por células vermelhas de ovelha (Maestroni et al., 1986). Além disso, a ocorrência de ritmos em alguns parâmetros imunológicos já foi verificada, como por exemplo, a produção de interleucina-2 (IL-2), cujo pico coincide com a produção noturna de melatonina (Carrillo-Vico et al., 2003), e a produção de IL-4, IL-5, IL-6, IL-10 e interferon gama (IFN- $\gamma$ ), os quais apresentam um ritmo de produção independente da produção noturna de melatonina (Pontes et al., 2007, Rief et al., 2010). Lange e colaboradores (2010) propõem que durante a noite o organismo está mais preparado para iniciar uma resposta adaptativa, enquanto que de dia, componentes inflamatórios constituem uma resposta efetora imediata. Assim, consideramos que o fenótipo das células endoteliais poderia variar de acordo com a hora do dia. Para testar essa hipótese, avaliamos células endoteliais em cultura obtidas de animais não tratados e mortos de dia ou de noite.

Demonstramos nesta dissertação, que células endoteliais obtidas de animais mortos à noite aderem menos neutrófilos e expressam menos moléculas de adesão e iNOS que células obtidas de animais mortos de dia. A menor capacidade de adesão de células obtidas durante a noite vai ao encontro dos achados in vivo que demonstram que melatonina em concentração compatível com a produção noturna inibe o rolamento e 
adesão de neutrófilo (Lotufo et al., 2001). Dessa forma, a reatividade de células endoteliais apresenta um ritmo de acordo com as concentrações de melatonina plasmática, visto que durante o pico de produção noturna de melatonina estas células se encontram em menor estado de ativação. Além disso, correlacionando a concentração plasmática de melatonina com o efeito observado nas células endoteliais, observamos que existe uma correlação inversa entre a concentração de melatonina e a expressão de moléculas de adesão e iNOS, reforçando a hipótese de que a melatonina prima as células endoteliais. Estratégias de privação da produção de melatonina pela glândula pineal devem ser utilizadas a fim de estabelecer mais relações entre a melatonina noturna e a reatividade do endotélio.

A melatonina atua por diferentes mecanismos de ação, ativando receptores de membranas específicos (para revisão, Dubocovich et al., 2010), e/ou agindo diretamente em alvos intracelulares (Benítez-King, 1993) ou em receptores nucleares (Becker-Andre et al., 1994). Ensaios farmacológicos de inibição do rolamento e da adesão de neutrófilos in vivo utilizando agonistas e antagonistas seletivos para receptores de melatonina sugerem que estes efeitos são mediados por receptores de melatonina do subtipo $\mathrm{MT}_{2}$ e $M T_{3}$, respectivamente (Lotufo et al., 2001). No entanto, estudos in vitro, avaliando a inibição da expressão de eNOS não confirmaram uma mediação via receptores $\mathrm{MT}$, sendo possível que este efeito seja mediado por interação direta com alvos intracelulares (Tamura et al., 2006). Da mesma forma, a melatonina reduz a expressão de iNOS induzida por LPS in vitro de maneira independente da ativação de receptores, visto que o antagonista não seletivo de receptores de melatonina, luzindol, não alterou o efeito da melatonina (Tamura et al., 2009).

É possível que haja um ritmo na expressão de receptores de melatonina em células endoteliais em função da produção rítmica de melatonina. Essa variação rítmica 
já foi descrita em outros tecidos e tipos celulares. Em retina de galinha, a expressão dos receptores $\mathrm{Mel}_{1 \mathrm{a}}$ e $\mathrm{Mel}_{1 \mathrm{~b}}$ (equivalentes aos receptores $\mathrm{MT}_{1}$ e $\mathrm{MT}_{2}$ em mamíferos, respectivamente) é maior durante a noite. Esta variação rítmica pode estar associada à regulação de processos dos tecidos oculares, uma vez que a produção de melatonina na retina é coordenada pelo ciclo claro/escuro (para revisão, Wiechmann \& Summers, 2008). Em glândulas adrenais de ratos verificou-se que a expressão do receptor $\mathrm{MT}_{1}$, mas não $\mathrm{MT}_{2}$, é maior à noite, sugerindo que a melatonina noturna atua sobre a produção de corticosterona em roedores (Richter et al., 2008). Desta forma, não podemos excluir a possibilidade de haver um ritmo de receptores ou sítios ligantes de melatonina ao longo do dia nas células endoteliais, na dependência da variação diária da concentração plasmática de melatonina.

Tendo confirmado o efeito inibidor da melatonina sobre a ativação de células endoteliais, é importante discutir os prováveis mecanismos de ação. Um mecanismo central na montagem de uma resposta inflamatória, que inclui o controle da expressão de moléculas de adesão (Ye et al., 2008) e iNOS (Heba et al., 2001) é o fator de transcrição NFKB. A melatonina atua sobre diferentes tipos celulares modulando o fator de transcrição NFKB. Melatonina inibe a expressão de iNOS em células endoteliais (Tamura et al., 2009), macrófagos (Gilad et al., 1998), glioma (Esposito et al., 2008) e edema de pata (Marino et al., 2009; Esposito et al., 2010), e a expressão de moléculas de adesão em células endoteliais (Sasaki et al., 2002) via inibição da translocação nuclear do NFKB. No entanto, vale chamar atenção que estes efeitos da melatonina são obtidos em uma faixa de concentração muito elevada $(\mu \mathrm{M}-\mathrm{mM})$, equivalente a uma produção local de melatonina.

É importante ressaltar que os parâmetros obtidos neste trabalho foram avaliados após 18 a 20 dias de cultura, sugerindo que estas células são capazes de armazenar uma 
memória das condições em que elas se encontravam no momento em que foram coletadas. As células coletadas durante a noite apresentam a mesma capacidade de adesão de neutrófilos que a observada in vivo por Lotufo e colaboradores (2001). Além disso, células obtidas de animais inflamados, estão mais ativadas que células provenientes de animais controle, mesmo após duas semanas em cultura. Os dados aqui apresentados sugerem que, para estocagem de células em bancos celulares, devem ser considerados o horário e as condições do doador, visto que a reatividade destas células pode ser modificada. Assim, este trabalho abre novas perspectivas para estudos em terapia celular.

Dados de outros autores já indicavam a capacidade de células endoteliais em cultura manterem memória em relação às condições dos animais doadores. Cavalcanti e colaboradores (2007) demonstraram que células endoteliais obtidas de animais adrenalectomizados aderem menos neutrófilos que células obtidas de animais falsooperados ou "naïve", mesmo após todos os procedimentos em cultura. Porém, a adrenalectomia não é uma condição facilmente encontrada, ao contrário de nosso protocolo experimental, o qual é baseado em condições mais fisiológicas.

Recentemente, Wang e colaboradores (2011) avaliaram as características de células endoteliais formadoras de colônia obtidas de pacientes com problemas cardíacos. Estas células foram avaliadas após algumas passagens in vitro. Após a terceira passagem, células endoteliais obtidas de pacientes hipertensos ou com doença coronária ou com diabetes estavam mais ativadas que células obtidas de sujeitos saudáveis. No entanto, a expressão fenotípica característica de células endoteliais, mas não as características de células ativadas, foram perdidas. Em células endoteliais obtidas de pacientes com dois tipos diferentes de malária, malária sem complicações ou malária cerebral, também foi observada uma diferença na capacidade de ativação frente a 
agentes inflamatórios, indicando que as informações dos doadores foram mantidas nas células em cultura (Wassmer et al., 2011).

Modelos de cultura ex vivo com outros tipos celulares também demonstram a presença de memória celular. Células imunológicas, como células B, são comumente conhecidas pela sua capacidade de armazenar memória celular a partir de uma sinalização por anticorpos (para revisão, Lanzavecchia et al., 2006). Células progenitoras neurais obtidas da zona subventricular de animais submetidos à lesão cerebral possuem maior capacidade proliferativa in vitro que células obtidas de animais controle, mesmo após 12 dias em cultura. Segundo o autor, as células progenitoras são primadas por mediadores produzidos por microglias, células abundantemente encontradas nos animais lesionados (Deierborg et al., 2010). No entanto, nenhum destes trabalhos foca a memória celular como um achado científico importante para padronizações nos procedimentos de cultura e terapia celulares.

O mecanismo molecular pelo qual as células endoteliais são primadas conservando uma memória das características da célula-mãe ainda não é bem compreendido. Fatores externos interferem no padrão de expressão molecular por meio de modificações na estrutura de acessibilidade do DNA. Atualmente, o termo “epigenética” se refere às alterações herdáveis da cromatina que não são decorrentes de mudanças na sequência do DNA. Em células endoteliais, diversos fatores integram os sinais extracelulares com a expressão gênica agindo epigeneticamente na regulação de uma série de mecanismos, como o tônus muscular. Dentre estes fatores podemos citar "shear stress", hipóxia, citocinas e mediadores do ciclo celular. Estudos envolvendo principalmente a expressão gênica da sintase de óxido nítrico endotelial (eNOS) colocam as células endoteliais como alvo de investigação no contexto da epigenética (para revisão, Yan et al., 2010). 
Em condições de hipóxia aguda a expressão do gene Nos3/enos em células endoteliais é epigeneticamente inibida, sendo esta condição revertida quando feita a reoxigenação. Além disso, em células mantidas em hipóxia crônica, histonas são reincorporadas à região promotora do gene (Fish et al., 2010). A expressão gênica de iNOS (Chan et al., 2005) e moléculas de adesão (Inoue et al., 2006) em células endoteliais é alterada por fatores epigenéticos desencadeados por sinalização de citocinas, como o TNF. Além disso, genes dependentes da ativação de NFKB são regulados por mecanismos epigenéticos a fim de se obter uma atividade transcricional apropriada (para revisão, Berghe et al., 2006).

Nesta dissertação demonstramos que a melatonina correlaciona-se inversamente com a expressão de iNOS e moléculas de adesão. A ausência ou baixa concentração de melatonina plasmática aumenta a reatividade de células endoteliais. Já foi demonstrada a capacidade da melatonina em agir epigeneticamente regulando a transcrição de genes. A melatonina é capaz de alterar padrões de acetilação de histonas em células progenitoras neurais, induzindo diferenciação (Sharma et al., 2008). Dessa forma, é possível que a melatonina seja capaz de agir epigeneticamente sobre as células endoteliais de maneira transiente, ou seja, acarretando alterações na acessibilidade de alguns genes que podem ser revertidas de acordo com o ritmo de produção deste hormônio ou com a diferença entre as concentrações de produção.

Enfim, demonstramos neste trabalho que a concentração plasmática de melatonina é capaz de primar células endoteliais de forma a torná-las menos ativadas ou susceptíveis à estimulação de agentes inflamatórios. Assim sendo, considerando transplantes de órgãos como uma prática clínica e que células endoteliais presentes nos vasos sanguíneos de todos os órgãos preservam uma memória de acordo com a concentração plasmática de melatonina do doador, os riscos de rejeição e/ou 
complicações seriam maiores naqueles indivíduos que recebessem doação de pacientes cujas células estariam em maior estado de ativação.

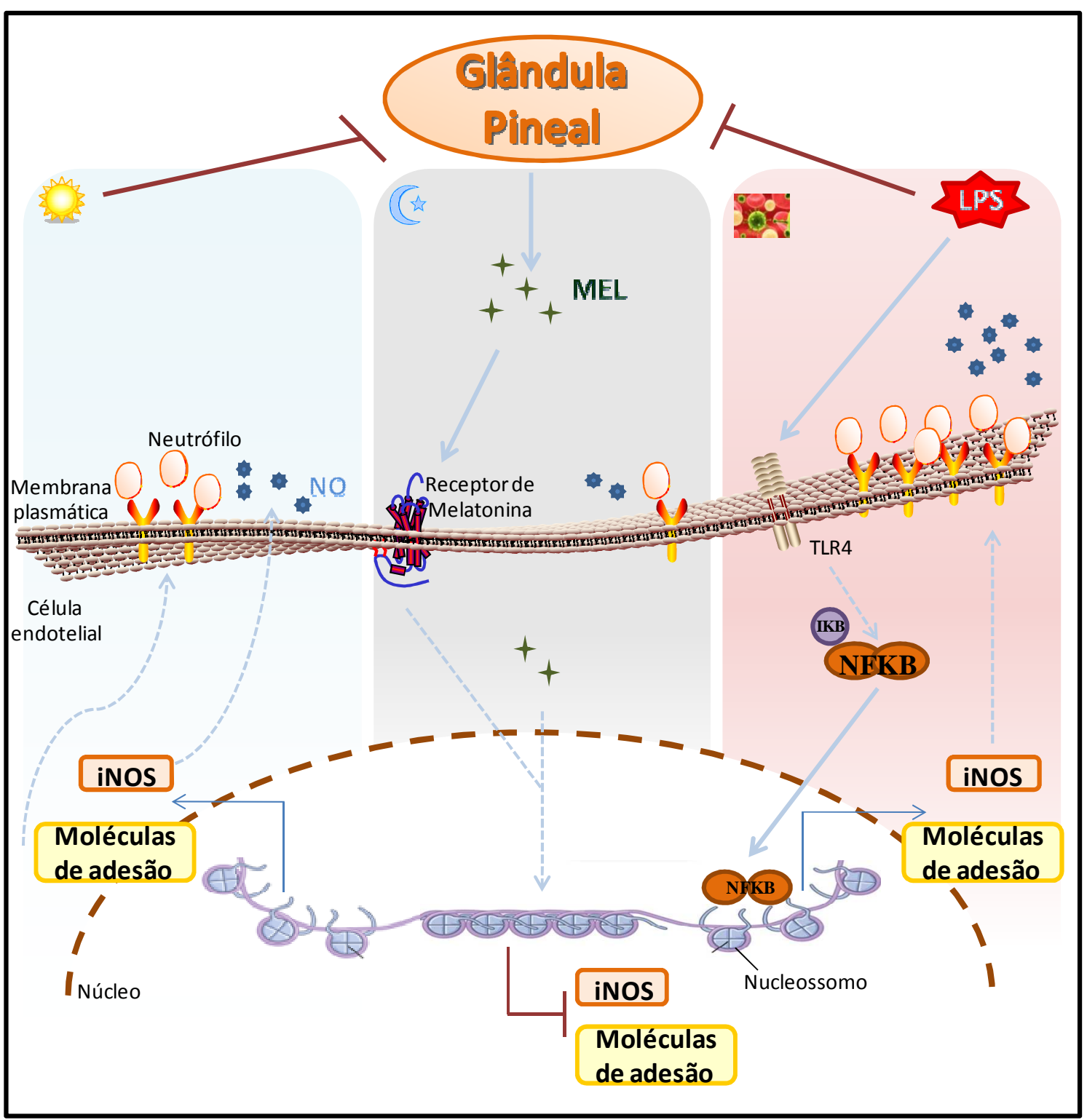

Figura 21 - Melatonina prima células endoteliais. A melatonina pode estar agindo epigeneticamente sobre as células endoteliais, fazendo com que estas armazenem uma memória celular com as informações do momento e condições em que foram obtidas. Essas informações são marcadas na estrutura da cromatina e passadas por gerações. Durante o dia, a informação luminosa captada pelas células ganglionares da retina inibe a síntese de melatonina pela glândula pineal. A ausência de melatonina permite que as células endoteliais sejam capazes de aderir mais neutrófilos e de expressar mais moléculas de adesão e iNOS do que células endoteliais obtidas à noite quando a produção de melatonina é maior. Na fase escura, é possível que as células endoteliais expressem receptores de melatonina na 
membrana, aumentando a sensibilidade a esta indolamina. Ainda, a melatonina pode agir diretamente em alvos intracelulares resultando numa ação sobre a conformação da cromatina. A melatonina primaria as células endoteliais à noite, diminuindo a acessibilidade da cromatina, fazendo com que esta se encontre mais condensada impedindo a transcrição gênica de moléculas de adesão e iNOS. Frente a um estímulo inflamatório, como o LPS, a produção rítmica de melatonina é diminuída, propiciando uma montagem da resposta inflamatória de maneira mais apropriada. O LPS e mediadores inflamatórios agiriam sobre as células endoteliais ativando o fator de transcrição nuclear NFKB, o qual migra para o núcleo e ativa a transcrição gênica de mediadores inflamatórios, como moléculas de adesão e iNOS. Neste momento, a cromatina torna-se mais acessível devido à diminuição da melatonina noturna. Coluna da esquerda (azul) - fase clara (dia); coluna central (cinza) - fase escura (noite); coluna da direita (rosa) - inflamação (LPS). 


\section{CONCLUSÕES}

1. O tratamento com LPS diminui a produção de melatonina pela glândula pineal, visto que é capaz de inibir a transcrição gênica da Aanat e reduzir a concentração plasmática de melatonina.

2. Células endoteliais obtidas de animais tratados com LPS duas horas antes da morte estão mais ativadas que células provenientes de animais não tratados ou tratados com veículo, no que diz respeito à expressão de iNOS, ICAM-1 e PECAM-1. Esta ativação ocorre independentemente do horário no qual o tratamento é feito. Além disso, LPS aumenta a capacidade de adesão de neutrófilos às células endoteliais, o que pode ser decorrente do aumento na expressão de moléculas de adesão.

3. A melatonina é capaz de reverter os efeitos acima descritos causados pelo tratamento com LPS.

4. A resposta gerada por LPS é transiente, visto que o tratamento com LPS duas, mas não seis horas antes da morte do animal aumenta a concentração plasmática de TNF e a reatividade de células endoteliais. Além disso, somente quando o tratamento é realizado duas horas antes, a produção de melatonina noturna é diminuída.

5. A reatividade de células endoteliais é diferente de acordo com a hora de obtenção. Células obtidas durante a noite estão menos ativadas que células obtidas de dia no que diz respeito à expressão de iNOS, ICAM-1 e PECAM-1. Células provenientes de animais mortos à noite aderem menos neutrófilos que células de animais mortos de dia. 
6. A melatonina é capaz de primar células endoteliais. Quanto maior a concentração plasmática de melatonina menor a expressão de iNOS, ICAM-1 e PECAM-1 em células endoteliais.

Os resultados apresentados nessa dissertação demonstraram que o estímulo inflamatório gerado por LPS é capaz de iniciar a montagem de uma resposta inflamatória independente da hora do dia, uma vez que o estímulo de LPS dado à noite inibe a produção noturna de melatonina. Este efeito é revertido após seis horas de tratamento, concluindo-se que uma fase de resolução da resposta inflamatória tenha sido implantada neste momento.

Considerando que as células endoteliais são importantes participantes na montagem da resposta inflamatória, nossos resultados também demonstraram que, mesmo após 18 a 20 dias em cultura, elas apresentaram as características do momento em que foram obtidas. Juntamente, nossos dados permitem concluir que as células endoteliais armazenam uma espécie de memória celular que conserva as características do estado do animal doador de acordo com as concentrações plasmáticas de melatonina.

Em suma, nossos dados vão ao encontro da teoria do eixo imune-pineal estabelecida pelo nosso grupo, na qual a concentração plasmática de melatonina compatível com a encontrada durante o pico noturno de produção interfere na reatividade de células endoteliais, inibindo a expressão de moléculas que participam da resposta inflamatória. Frente a estímulo por LPS, a produção noturna de melatonina é diminuída, permitindo que a montagem da resposta ocorra independente da hora do dia. Depois de instaurada a fase de resolução, a produção de melatonina pela pineal é restaurada e esta atua diminuindo a atividade de células endoteliais. Dessa forma, é 
possível que a melatonina esteja agindo epigeneticamente sobre a transcrição gênica de células endoteliais de acordo com sua concentração plasmática. 


\section{RESUMO/ABSTRACT}




\section{RESUMO}

O endotélio é a camada celular interna dos vasos sanguíneos, responsável pela homeostase vascular. Além disso, é a porta de entrada para as células de defesa frente a um quadro de inflamação. A camada endotelial é alvo de diversos estudos devido ao seu caráter de fácil expansão em cultura, porém sua biologia ainda não é completamente compreendida. Devido à sua localização privilegiada, o endotélio está susceptível a alterações da composição da corrente sanguínea. A melatonina, hormônio produzido ritmicamente pela glândula pineal e de forma não rítmica em diversos outros tecidos, tem propriedade citoprotetora. Diversos estudos já demonstraram que ela atua, por diferentes mecanismos de ação e faixas de concentração, como um mediador antiinflamatório sobre o endotélio. Segundo a hipótese de trabalho de nosso grupo, o eixo imune-pineal, a glândula pineal e o sistema imunológico se interligam em uma comunicação bidirecional, na qual a produção rítmica de melatonina é inibida frente a um quadro de inflamação para que ocorra a montagem da resposta inflamatória independente da hora do dia. Assim sendo, esta dissertação se baseou na hipótese de que as células endoteliais apresentam um ritmo em sua maquinaria que altere a intensidade de resposta frente a um estímulo inflamatório, e propôs avaliar como a melatonina agiria na regulação desse ritmo. Dessa forma, avaliamos como o tratamento sistêmico com LPS afetaria a produção noturna de melatonina, modulando a reatividade de células endoteliais da microcirculação. Demonstramos que o tratamento com LPS diminui os níveis circulantes deste hormônio e inibe a transcrição gênica da enzima chave, AA-NAT. Na periferia, o tratamento com LPS aumenta a reatividade de células endoteliais independente da hora do dia de administração mesmo após 18 dias em 
cultura. Este efeito é transiente, pois quando o tratamento é realizado seis horas antes da morte, os parâmetros analisados retornam aos níveis basais. A melatonina, administrada juntamente com LPS, reverte o efeito do LPS sobre as células endoteliais, além de reduzir a concentração plasmática de TNF. Além disso, células endoteliais obtidas de animais mortos à noite possuem menor estado de ativação que células provenientes de animais mortos de dia. De maneira geral, o efeito observado sobre as células endoteliais é inversamente correlacionado com a concentração plasmática de melatonina. Esses dados sugerem que as células endoteliais possuem uma espécie de "memória celular", pois armazenam as informações do estado do animal doador mesmo após todos os procedimentos em cultura. Adicionalmente, demonstramos a dinâmica do eixo imunepineal in vivo. Juntamente, nossos dados permitem concluir que a melatonina prima as células endoteliais, modulando sua reatividade de acordo com a hora do dia e o estado de saúde do animal. 


\section{VIII. $\mathcal{A B S T \mathcal { R A C T }}$}

The endothelium is the vascular internal cellular layer, responsible for vascular homeostasis. Additionally, it regulates immune cells entrance during an inflammatory response. The endothelial layer is the focus of many studies due to its facility of culture expansion, but its biology is not yet totally understood. Because of its privileged localization, the endothelium is susceptible to plasma compounds changes. Melatonin, rhythmically produced by pineal gland and in a non rhythm way in others tissues, has citoprotector properties. Many studies have already shown that melatonin acts on endothelium as an anti-inflammatory mediator, through different mechanisms of action and concentrations ranges. Considering our work hypothesis, the immune-pineal axis, that suggests that the pineal gland and immune system are integrated through a bidirectional communication, melatonin rhythm production is inhibited during an injury, permitting the mounting of immune response independently of the hour of the day. This dissertation is based on the hypothesis that endothelial cells presents a rhythm in its machinery that alters the response intensity due to an inflammatory stimuli. We analyzed how LPS systemic treatment affects the melatonin nocturnal production, modulating the endothelial cells reactivity of microcirculation. We demonstrated that LPS treatment reduced plasma melatonin level and inhibited gene transcription of key enzyme, AA-NAT. On the periphery, LPS treatment increased endothelial cells reactivity independently of the hour of the day even after 18 days in culture. This effect was transient, once the parameters analyzed returned to basal levels when the treatment was done six hours before the death. Melatonin administrated together with LPS, reverted LPS effects on the endothelial cells, and also reduced plasma TNF 
concentration. Endothelial cells obtained from animal killed at nighttime are more activated than cells obtained from animals killed at daytime. Generally, the endothelial cells effects are inversely correlated with plasma melatonin level. These data suggests that endothelial cells have a "cellular memory", because they are capable to retain the information of donor animal state even after all culture proceedings. Additionally, we demonstrated the immune-pineal axis dynamics in vivo. All together, our results permit to conclude that melatonin primes the endothelial cells, modulating their reactivity according to the hour of the day and donor animal health. 


\section{REFER $\hat{E} \mathcal{N} C I \mathcal{A} S$ BIBLIOGRÁAICAS}




\section{IX. $\quad$ REFER $\hat{E} \mathcal{N} C I \mathcal{A} S$ BIBLIOGRÁAICAS}

AIRD, W. C. (2007). Phenotypic heterogeneity of the endothelium: I. Structure, function and mechanisms. Circ. Res., 100(2):158-173.

ANWAR, M.M., MEKI, A.R. \& RAHMA, H.H. (2001). Inhibitory effects of melatonin on vascular reactivity: possible role of vasoactive mediators. Comp. Biochem. Physiol. C.Toxicol. Pharmacol., 130(3):357-367.

ARENDT, J. \& MARKS, V. (1982). Physiological changes underlying jet lag. Br. Med. J., 284(6310):144-146.

BAILES, H. J., LUCAS, R.J. (2010). Melanopsin and inner retinal photoreception. Cell. Mol. Life Sci., 67:99-111.

BALZER, I., HÖCKER, B., KAPP, H. \& BARTOLOMAEUS, B. (2000). Occurrence and comparative physiology of melatonin in evolutionary diverse organisms. In: The Redox State and Circadian Rhythms. Vanden Driessche, T., Guisset, J.-L. \& Petieau-de Vries, G. M., eds. Kluwer, Dordrecht, pp. 95-119.

BECKER-ANDRE, M., WIESENBERG, I., SCHAEREN-WIEMERS, N., ANDRE, E., MISSBACH, M., SAURAT, J.H. \& CARLBERG, C. (1994). Pineal gland hormone melatonin binds and activates an orphan of the nuclear receptor superfamily. J. Biol. Chem., 269:28531-28534.

BECKER-ANDRE, M., WIESENBERG, I., SCHAEREN-WIEMERS, N., ANDRE, E., MISSBACH, M., SAURAT, J.H. \& CARLBERG, C. (1997). Additions and corrections. Pineal gland hormone melatonin binds and activates an orphan of the nuclear receptor superfamily. J. Biol. Chem., 272:16707. 
BENÍTEZ-KING, G. \& ANTÓN-TAY, F. (1993). Calmodulin mediates melatonin cytoskeletal effects. Experientia, 49:635-641.

BERGHE, V.W, NDLYU, M.N., HOYA-ARIAS, R., DIJSSELBLOOEM, N., GERLO, S. \& HAEGEMAN, G. (2006). Keeping up NF-kappaB appearances: epigenetic control of immunity or inflammation-triggered epigenetics. Biochem. Pharmacol, 72(9):1114-1131.

BIBB, J.A., MAYFORD, M.R., TSIEN, J.Z. \& ALBERINI, C.M. (2010). Cognition enhancement strategies. J. Neurosci., 30(45):14987-14992.

BOGATCHEVA, N.V. \& VERIN, A.D. (2008). The role of cytoskeleton in the regulation of vascular endothelial barrier function. Microvasc. Res., 76(3):202207.

BONIZZI, G. \& KARIN, M. (2004). The two NF-кB activation pathways and their role in innate and adaptative immunity. Trends Immunol., 25:280-288.

BORJIGIN, J., WANG, M.M. \& SNYDER, S.H. (2005). Diurnal variation in mRNA encoding serotonin $\mathrm{N}$-acetyltransferase in pineal gland. Nature, 378(6559):783-5. BRAINARD, G.C., WATSON-WHITMEYER, M., KNOBLER, R.L. \& LUBLIN F.D. (1988). Neuroendocrine regulation of immune parameters. Photoperiod control of the spleen in Syrian hamsters. Ann. N.Y. Acad. Sci., 540:704-6.

BRAS, A., VIJAYARAJ, P. \& OETTGEN, P. (2010). Molecular mechanisms of endothelial differentiation.Vasc. Med.,15(4):321-331.

BRUCK, R., AEED, H., AVNI, Y., SHIRIN, N., MATAS, Z., SHAHMUROV, M., AVINOACH, I., ZOZULYA, G., WEIZMAN, N. \& HOCHAMN, A. (2004). Melatonin inhibits nuclear factor kappa B activation and oxidative stress and protects against thioacetamide induced liver damage in rats. J. Hepatol., 40(1):8693. 
BUBENIK, G.A., BALL, R.O. \& PANG, S.F. (1992). The effect of food deprivation on brain and gastrointestinal tissue levels of tryptophan, serotonin, 5hydroxyindoleacetic acid, and melatonin. J Pineal Res., 12(1):7-16.

CABALlERO, B., VEGA-NAREDO, I., SIERRA, V., HUIDOBRO-FERNÁNDEZ, C., SORIA-VALlES, C., DE GONZALO-CALVO, D., TOLIVIA, D., UTIERREZCUESTA， J., PALLAS, M., CAMINS, A., RODRÍGUEZCOLUNGA, M.J. \& COTO-MONTES, A. (2008). Favorable effects of a prolonged treatment with melatonin on the level of oxidative damage and neurodegeneration in senescence-accelerated mice. J. Pineal Res., 45(3):302-311.

CARDINALI, D.P., LYNCH, H.J. \& WURTMAN, R.J. (1972). Binding of melatonin to human and rat plasma proteins. Endocrinology, 91(5):1213-1218.

CARRILlO-VICO, A., GARCIA-MAURINO, S., CALVO, J.R. \& GUERRERO, J.M. (2003). Melatonin counteracts the inhibitory effect of PGE2 on IL-2 production in human lymphocytes via its mt1 membrane receptor. FASEB J., 17(6):755-7.

CARRILlO-VICO, A., CALVO, J.R., ABREU, P., LARDONE, P.J., GARCIAMAURINO, S.,REITER, R.J. \& GUERRERO, J.M. (2004). Evidence of melatonin synthesis by human lymphocytes and its physiological significance: possible role as intracrine, autocrine, and/or paracrine substance. FASEB J., 18(3):537-9.

CARRILLO-VICO, A., GUERRERO, J.M., LARDONE, P.J. \& REITER, R.J. (2005a). A review of the multiple actions of melatonin on the immune system. Endocrine, 27(2):189-200.

CARRILLO-VICO, A., LARDONE, P.J., NAJI, L., FERNÁNDEZ-SANTOS, J.M., MARTÍN-LACAVE, I., GUERRERO, J.M. \& CALVO, J.R. (2005b). Beneficial pleiotropic actions of melatonin in an experimental model of septic shock in mice: 
regulation of pro-/anti-inflammatory cytokine network, protection against oxidative damage and anti-apoptotic effects. J. Pineal Res., 39(4):400-408.

CARVALHO-SOUSA, C.E., DA SILVEIRA CRUZ-MACHADO, S., TAMURA, E.K., FERNANDES, P.A.C.M., PINATO, L., MUXEL, S.M., CECON, E. \& MARKUS, R.P. (2011). Molecular basis for defining the pineal gland and pinealocytes as targets for tumor necrosis factor. Frontiers Endocrinol., 2(10):111.

CAVALCANTI, D.M.H., LOTUFO, C.M.C., BORELLI, P., FERREIRA, Z.S., MARKUS, R.P. \& FARSKY, S.H.P. (2007). Endogenous glucocorticoids control neutrophil mobilization from bone marrow to blood and tissues in noninflammatory conditions. Br. J.Pharmacol., 152(8):1291-1300.

CECON, E., FERNANDES, P.A., FERREIRA, Z.S. \& MARKUS, R.P. (2010). Daily variation of constitutively activated nuclear factor kappa B (NF-kB) in rat pineal gland. Chronobiol. Int., 27(1):52-67.

CHAMBERS, R. \& ZWEIFACH, B.W. (1947). Intercellular cement and capillary permeability. Physiol. Rev., 27:436-463.

CHAN, G.C., FISH, J.E., MAWJI, I.A., LEUNG, D.D., RACHLIS, A.C. \& MARSDEN, P.A. (2005). Epigenetic basis for the transcriptional hyporesponsiveness of the human inducible nitric oxide synthase gene in vascular endothelial cells. J. Immunol., 175:3846-3861.

CHEN, S.F., FEI, X. \& LI, S.H. (1995). A new simple method for isolation of microvascular endothelial cells avoiding both chemical and mechanical injuries. Microvasc. Res., 50(1):119-128.

COOK-MILLS, J.M. \& DEEM, T.L. (2005). Active participation of endothelial cells in inflammation. J. Leukoc. Biol., 77:487-495. 
COON, S.L., ROSEBOOM, P.H., BALER, R., WELLER, J.L., NAMBOODIRI, M.A., KOONIN, E.V., KLEIN, D.C. (1995). Pineal serotonin N-acetyltransferase: expression cloning and molecular analysis. Science, 270:681-1683.

COPLEY, A.L. (1974). Hemorheological aspects of the endothelium- plasma interface. Microvasc. Res., 8:192-212.

CSABA, G. \& BARATH, P. (1975). Morphological changes of thymus and the thyroid gland after postnatal extirpation of pineal body. Endocrinol. Exp., 9: 59-67.

CUI, P., LUO, Z., ZHANG, H., SU, Y., LI, A., ZHANG, J., YANG, Z. \& XIU, R. (2006). Effect and mechanism of melatonin's action on the proliferation of human umbilical vein endothelial cells. J. Pineal Res., 41(4):358-362.

CUI, P., YU, M., LUO, Z., DAI, M., HAN, J., XIU, R. \& YANG, Z. (2008). Intracellular signaling pathways involved in cell growth inhibition of human umbilical vein endothelial cells by melatonin. J. Pineal Res., 44(1):107-114.

CUZZOCREA, S., COSTANTINO, G., MAZZON, E., MICALI, A., DE SARRO, A. \& CAPUTI, A.P. (2000). Beneficial effects of melatonin in a rat model of splanchnic artery occlusion and reperfusion. J. Pineal Res., 28(1):52-63.

DA SILVEIRA CRUZ-MACHADO. S., CARVALHO-SOUSA, C.E., TAMURA, E.K., PINATO, L., CECON, E., FERNANDES, P.A., DE AVELLAR, M.C., FERREIRA, Z.S. \& MARKUS RP. (2010). TLR4 and CD14 receptors expressed in rat pineal gland trigger NFKB pathway. J Pineal Res. 49(2):183-192.

DAI, J., RAM, P.T., YUAN, L., SPRIGGS, L.L. \& HILL, S.M. (2001). Transcriptional repression of RORalpha activity in human breast cancer cells by melatonin. Mol. Cell Endocrinol., 176(1-2): 111-120. 
DAI, M., CUI, P., YU, M., HAN, J., LI, H. \& XIU, R. (2008). Melatonin modulates the expression of VEGF and HIF-1 alpha induced by $\mathrm{CoCl} 2$ in cultured cancer cells. J. Pineal Res., 44(2):121-6.

DANIELLI, J.F. (1949). Capillary permeability and oedema in the perfused frog. $J$. Physiol., 98:109-129.

DAUPHINNE, S.M. \& KARSAN, A. (2006). Lipopolysaccharide signaling in endothelial cells. Lab. Invest., 86(1):9-22.

DE VAL, S. \& BLACK, B.L. (2009). Transcriptional control of endothelial cell development. Dev. Cell,16(2):180-195.

DEIERBORG, T., ROYBON, L., INACIO, A.R., PESIC, J. \& BRUNDIN, P. (2010). Brain injury activates microglia that induce neural stem cell proliferation ex vivo and promote differentiation of neurosphere-derived cells into neurons and oligodendrocytes. Neuroscience, 171(4):1386-1396.

DENNINGER, J.W. \& MARLETTA, M.A. (1999). Guanylate ciclase and the NO/cGMP signaling pathway. Biochim. Biophys. Acta, 1411:334-350.

DUBOCOVICH, M.L. (1988). Pharmacology and function of melatonin receptors. FASEB J., 2(12):2765-2773.

DUBOCOVICH, M.L., MASANA, M.I., IACOB, S. \& SAURI, D.M. (1997). Melatonin receptor antagonists that differentiate between the human Mella and Mel1b recombinant subtypes are used to assess the pharmacological profile of the rabbit retina ML1 presynaptic heteroreceptor. Naunyn. Schmiedebergs. Arch. Pharmacol.,355(3): 365-375.

DUBOCOVICH, M.L., DELAGRANGE, P., KRAUSE, D.N., SUGDEN, D. CARDINALI, D.P. \& OLCESE, J. (2010). International Union of Basic and 
clinical Pharmacology. LXXV. Nomenclature, classification and pharmacology of G protein-coupled melatonin receptors. Pharmacol Rev., 62(3): 343-380.

ESPOSITO, E., IACONO, A., MUIÀ, C., CRISAFUlli, C., MATTACE-RASO, G., MELI, R. \& CRUZZOCREA, S. (2008). Signal transduction pathways involved in protective effects of melatonin in C6 glioma cells. J. Pineal Res., 44(1):78-87.

ESPOSITO, E., PATERNITI, I., MAZZON, E., BRAMANTI, P. \& CRUZZOCREA, S. (2010). Melatonin reduces hyperalgesia associated with inflammation. J. Pineal Res.,49(4):321-331.

FERNANDES, P.A., CECON, E., MARKUS, R.P. \& FERREIRA, Z.S. (2006). Effect of TNF-alpha on the melatonin synthetic pathway in the rat pineal gland: basis for a 'feedback' of the immune response on circadian timing. J. Pineal Res. 41(4):344350.

FERNANDES, P.A., BOTHOREL, B., CLESSE, D., MONTEIRO, A.W., CALGARI, C., RAISON, S., SIMONNEAUX, V. \& MARKUS, R.P. (2009). Local corticosterone infusion enhances nocturnal pineal melatonin production in vivo. $J$. Neuroendocrinol., 21(2):90-97.

FERREIRA, Z.S., FERNANDES, P.A., DUMA, D., ASSREUY, J., AVELLAR, M.C.W. \& MARKUS, R.P., (2005). Corticosterone modulates noradrenalineinduced melatonin synthesis through inhibition of nuclear factor kappa B. $J$. Pineal Res., 38:82-88.

FISH, J.E., YAN, M.S., MATOUK, C.C, ST BERNARD, R., HO, J.J., GAVRYUSHOVA, A., SRIVASTAVA, D. \& MARSDEN, P.A. Hypoxic repression of endothelial nitric-oxide synthase transcription is coupled with eviction of promoter histones. J. Biol. Chem., 285(2):810-826. 
FOSTER, C.E., BIANCHET, M.A., TALALAY, P., FAIG, M. \& AMZEL, L.M. (2000) Structures of mammalian cytosolic quinone reductases. Free Radic. Biol. Med., 29:41-245.

FURCHGOTT, R. F. \& ZAWADZKI, J. V. (1980). The obligatory role of endothelial cellsin the relaxation of arterial smooth muscle by acetylcholine. Nature, 288:373376.

GALIJASEVIC, S., ABDULHAMID, I. \& ABU-SOUD, H. M. (2008) Melatonin is a potent inhibitor for myeloperoxidase. Biochemistry, 47:2668-2677

GANGULY, S., GASTEL, J.A., WELLER, J.L., SCHWARTZ, C., JAFFE, H., NAMBOODIRI, M.A., COON, S.L., HICKMAN, A.B, ROLLAG, M., OBSIL, T., BEAUVERGER, P., FERRY, G., BOUTIN, J.A. \& LEIN, D.C. (2001). Role of a pineal cAMP-operated arylalkylamine $\mathrm{N}$-acetiltransferase/14-3-3-binding switch in melatonin synthesis. Proc. Natl. Acad. Sci. USA, 98:8083-8088.

GARCIA-MAURIÑO, S., GONZALEZ-HABA, M.G., CALVO, J.R., GOBERNA, R. \& GUERRERO, J.M. (1998). Involvement of nuclear binding sites for melatonin in the regulation of IL-2 and IL-6 production by human blood mononuclear cells. J. Neuroimmunol., 92: 76-84.

GERSHON, M.D. (1999). Review article: roles played by 5-hydroxytryptamine in the physiology of the bowel. Aliment. Pharmacol. Ther., 2:15-30.

GHOSH, S. \& KARIN, M. (2002). Missing pieces in the NF-kappaB puzzle. Cell, 109:81-96.

GILAD, E., CUZZOCREA, S., ZINGARELli, B., SAlZMAN, A.L. \& SZABÓ, C. (1997). Melatonin is a scavenger of peroxynitrite. Life Sciences, 60(10):169-174.

GILAD, E., WONG, H.R., ZINGARELLI, B., VIRÁG, L., O’OCONNOR, M., SALZMAN, A.L. \& SZABÓ, C. (1998). Melatonin inhibits expression of the 
inducible isoforms of nitric oxide synthase in murine macrophages: role of inhibition of NFkB. FASEB J., 12:685-693.

GIMBRONE, M.A. Jr., COTRAN, R.S. \& FOLKMAN, J. (1974). Human vascular endothelial cells in culture: Growth and DNA synthesis. J. Cell Biol., 60(3):67384.

HARDELAND, R. \& FUHRBERG, B. (1996). Ubiquitous melatonin - presence and effects in unicells, plants and animals. Trends Comp. Biochem. Physiol. 2:25-45.

HARDELAND, R. (1999). Melatonin and 5-methoxytryptamine in non-metazoans. Reprod. Nutr. Dev., 39:399-408.

HEBA, G., KRZEMINSKI, T., PORC, M. GRZYB, J. \& DEMBINSKA-KIEC, A. (2001). Relation between expression of TNF alpha, iNOS, VEGF mRNA and development of heart failure after experimental myocardial infarction in rats. $J$. Physiol. Pharmacol., 52:39-52.

HIBAOUI, Y., ROULET, E. \& RUEGG, U. T. (2009) Melatonin prevents oxidative stress-mediated mitochondrial permeability transition and death in skeletal muscle cells. J. Pineal Res., 47:238-252

HIRATA, F., HAYAISHI, O., TOKUYAMA, T. \& SENO, S. (1974). In vitro and in vivo formation of two new metabolites of melatonin. J. Biol. Chem., 249:13111313.

HOTTA, C.T., GAZARINI, M.L., BERALDO, F.H., VAROTTI, F.P., LOPES, C., MARKUS, R.P., POZZAN, T. \& GARCIA, C.R. (2000). Calcium-dependent modulation by melatonin of the circadian rhythm in malarial parasites. Nat. Cell Biol., 2(7):466-468.

INOUE, K., KOBAYASHI, M., YANO, K., MIURA, M., IZUMI, A., MATAKI, C., DOI, T., HAMAKUBO, T., REID, P.C., HUME, D.A., YOSHIDA, M., AIRD, 
W.C., KODAMA, T. \& MINAMI, T. (2006). Histone deacetylase inhibitor reduces monocyte adhesion to endothelium through the suppression of vascular cell adhesion molecule-1 expression. Arterioscler. Thromb. Vasc. Biol., 26:26522659.

ISENBERG, J.S. (2003). Inhibition of nitric oxide synthase (NOS) conversion of Larginine to nitric oxide (NO) decreases low density mononuclear cell (LD MNC) trans-endothelial migration and cytokine output. J. Surg. Res., 114(1):100-106.

JANKOVIC, B. D., KNEZEVIC, Z., KOJIC, L., AND NIKOLIC, V. (1994). Pineal gland and immune system. Immune functions in the chick embryo pinealectomized at 96 hours of incubation. Ann. NY Acad. Sci., 719:398-409.

JU, H., VENEMA, V.J., MARRERO, M.B. \& VENEMA, R.C. (1998). Inhibitory interactions of the bradykinin B2 receptors with endothelial nitric-oxide synthase. J. Biol. Chem., 273(37): 24025-24029.

KAKIZAKI, Y., WATANOBE, H., KOHSAKA, A. \& SUDA, T. (1999). Temporal profiles of interleukin-1beta, interleukin-6, and tumor necrosis factor-alpha in the plasma and hypothalamic paraventricular nucleus after intravenous or intraperitoneal administration of Lipopolysaccharide in the rat: estimation by push-pull perfusion. Endocr. J., 46:487-496.

KALSBEEK, A., CUTRERA, R.A., VAN HEERIKHUIZE, J.J., VAN DER VLIET, J., BUIJS, R.M. (1999). GABA release from suprachiasmatic nucleus terminals is necessary for the light-induced inhibition of nocturnal melatonin release in the rat. Neurosci., 91(2):453-61.

KALSBEEK, A., GARIDOU, M.L., PALM, I.F., VAN DER VLIET, J., SIMONNEAUX, V., PÉVET, P. \& BUIJS, R.M. (2000). Melatonin sees the light: 
blocking GABA-ergic transmission in the paraventricular nucleus induces daytime secretion of melatonin. Eur J Neurosci., 12(9): 3146-3154.

KARIN, M. \& BEN-NERIAH, Y. (2000). Phosphorylation meets ubiquitination: the control of NF-кB activity. Annu. Rev. Immunol., 18:621-63.

KAWAI, T., AKIRA, S. (2007). Signaling to NF-kB by toll-like receptos. Trends Mol. Med., 13:460-469.

KEDZIERSKI, R.M. \& YANAGISAWA, M. (2001). Endothelin system: The oubleedged sword in health and disease. Annu. Rev. Pharmacol. Toxicol.,41:851876.

KLEIN, D.C., COON, S.L.; ROSEBOOM, P.H., Weller, J.L., BERNARD, M., GASTEL, J.A., ZATZ, M., IUVONE, M., RODRIGUEZ, I.R., BÉGAY, V., FLCON, J., CAHILL, G.M., COSSONE, V.M. \& BALER, R. (1997). The melatonin rhythm-generating enzyme: molecular regulation of serotonin $\mathrm{n}$ acetyltransferase in the pineal gland. Recent Progress in Hormone Res., 52:307358.

KVETNOY, I. M. (1999). Extrapineal melatonin: location and role within diffuse neuroendocrine system. Histochem. J., 31,1-12.

LAHIRI, D.K., GE, Y.W., SHARMAN, E.H. \& BONDY, S.C. (2004). Age-related changes in serum melatonin in mice: higher levels of combined melatonin and 6hydroxymelatonin sulfate in the cerebral cortex than serum, heart, liver and kidney tissues. J Pineal Res., 36:217-223.

LANGE, T., DIMITROV, S. \& BRON, J. (2010). Effects of sleep and circadian rhythm on the human immune system. Ann. N.Y. Acad. Sci.,1193:48-59. 
LANOIX, D., BEGHDADI, H., LAFOND, J. \& VAILLANCOURT, C. (2008). Human placental trophoblasts synthesize melatonin and express its receptors. J. Pineal Res., 45(1): 50-60.

LANZAVECCHIA, A., BERNASCONI, N., TRAGGIAI, E., RUPRECHT, C.R., CORTI, D., SALLUSTO, F. (2006). Understanding and making use of human memory B cells. Immunol. Rev., 211:303-309.

LARDONE, P.J., CARRILlO-VICO, A., NARANJO, M.C., DE FELIPE, B., VALLEJO, A., KARASEK, M. \& GUERRERO, J.M. (2006). Melatonin synthesized by Jurkat human leukemic $\mathrm{T}$ cell line is implicated in IL-2 production. J. Cell Physiol., 206(1): 273-279.

LAWSON, C. \& WOLF, S. (2009). ICAM-1 signaling in endothelial cells. Pharmacol. Rep., 61(1):22-32.

LERNER, A.B., TAKAHASHI, Y., LEE, T.H. \& MORI, W. (1958). Isolation of melatonin, the pineal gland factor that lightens melanocytes. J. Am. Chem. Soc., 80: 2587.

LI, Q. \& VERMA, I.M. (2002). NF-kB regulation in the immune system. Nat. Rev. Immunol., 2: 25-734.

LIU, L. \& KUBES, P. (2003). Molecular mechanisms of leukocyte recruitment: organspecific mechanisms of action. Thromb. Haemost., 89:213-20.

LOPES, C., DELYRA, J.L., MARKUS, R.P. \& MARIANO, M. (1997). Circadian rhythm in experimental granulomatous inflammation is modulated by melatonin. J. Pineal Res., 23:72-78.

LOTUFO, C.M., LOPES, C., DUBOCOVICH, M.L., FARSKY, S.H. \& MARKUS, R.P. (2001). Melatonin and N-acetylserotonin inhibit leukocyte rolling and adhesion to rat microcirculation. Eur. J. Pharmacol., 430:351-357. 
LOTUFO, C.M., YAMASHITA, C.E., FARSKY, S.H. \& MARKUS, R.P. (2006). Melatonin effect on endothelial cells reduces vascular permeability increase induced by leukotriene B4. Eur. J. Pharmacol., 534(1-3):258-263.

LUCHETti, F., CANONiCO, B., BETti,M., ARCANGElETti, M., PILOLli, F., PIRODDI, M., CANESI, L., PAPA, S. \& GALLI, F. (2010). Melatonin signaling and cell protection function. FASEB J., 24:3603-3624.

LUFT, J.H. (1966). Fine structure of capillary and endocapillary layer as revealed by ruthenium red. Microcirc. Symp. Fed. Proc., 25:1773-1783.

MACÍAS, M., RODRÍGUEZ-CABEZAS, M.N., REITER, R. J., OSUNA, A. \& ACUÑA-CASTROVIEJO, D. (1999). Presence and effects of melatonin in Trypanosoma cruzi. J. Pineal Res., 27:86-94.

MAESTRONI, G.J., CONTI, A., \& PIERPAOLI, W. (1986). Role of the pineal gland in immunity. Circadian synthesis and release of melatonin modulates the antibody response and antagonizes the immunosuppressive effect of corticosterone.J. Neuroimmunol., 13:19-30.

MANCHESTER, L. C., POEGGElER, B., AlVARES, F. L., OGDEN,G. B. \& REITER, R. J. (1995). Melatonin immunoreactivity in the photosynthetic prokaryote Rhodospirillum rubrum: implications for an ancient antioxidant system. Cell. Mol. Bio. Res., 41:391-395.

MARINO, A., DI PAOLA, R., CRISAFUlli, C., MAZZON, E., MORABITO, R., PATERNITI, I., GALUPPO, M., GENOVESE, T., LA SPADA, G. \& CUZZOCREA, S. (2009). Protective effect of melatonin against the inflammatory response elicited by crude venom from isolated nematocysts of Pelagia noctiluca (Cnidaria, Scyphozoa). J. Pineal Res., 47(1):56-69. 
MARKUS, R.P., FERREIRA, Z.S., FERNANDES, P.A.C.M. \& CECON, E. (2007). The immune-pineal axis: a shuttle between endocrine and paracrine melatonin sources. Neuroimmunomodulation, 14:126-133.

MARKUS, R.P., SILVA, C.L.M, FRANCO, D.G., BARBOSA JR. E.M. \& FERREIRA, Z.S. (2010). Is modulation of nicotinic acetylcholine receptors by melatonin relevant for therapy with cholinergic drugs? Pharmacol. Ther. 126(3):251-262.

MARTIN, L. B., WEIL, Z. M. \& NELSON, R. J. (2008). Seasonal changes in vertebrate immune activity: mediation by physiological trade-offs. Philos.Trans.R.Soc.Lond.B.Biol.Sci., 363:321-339.

MARTINS, E., FERREIRA, A.C.F., SKORUPA, A.L., AFECHE, S.C., CIPOLLANETO, J. \& COSTA-ROSA, L.F.B.P. (2004). Tryptophan consumption and indoleamines production by peritoneal cavity macrophages. J. Leukoc. Biol., 75:1116-1121.

MAYO J.C., SAINZ, R.M., TAN D.X., HARDELAND, R., LEON, J., RODRIGUEZ, C. \& REITER, R.J. (2005). Anti-inflammatory actions of melatonin and its metabolites, N1-acetyl-N2-formyl-5- methoxykynuramine (AFMK) and N1acetyl-5-methoxykynuramine (AMK), in macrophages. J. Neuroimmunol., 165:139-149.

MENENDEZ-PELAEZ, A., POEGGELER, B., REITER, R.J., BARLOW-WALDEN, L., PABLOS, M.I. \& TAN, D.X. (1993). Nuclear localization of melatonin in different mammalian tissues: immunocytochemical and radioimmunoassay evidence. J. Cell. Biochem., 53(4): 373 - 382.

MIAS, C., TROUCHE, E., SEGUELAS, M.H., CALCAGNO, F., DIGNATGEORGE, F., SABATIER, F.,PIERCECCHI-MARTI, M.D., DANIEL, L., BIANCHI, P., 
CALISE, D., BOURIN, P., PARINI, A. \& CUSSAC, D. (2008). Ex vivo pretreatment with melatonin improves survival, proangiogenic/mitogenic activity, and efficiency of mesenchymal stem cells injected into ischemic kidney. Stem Cells, 26(7):1749-1757.

MICHEL, J.B., FERON, O., SACKS, D. \& MICHEL, T. (1997). Reciprocal regulation of endothelial nitric-oxide synthase by $\mathrm{Ca}^{2+}$-calmodulin and caveolin. J. Biol. Chem., 272(25):15583-15586.

MICHIELS, C. (2003). Endothelial cell functions. J. Cell. Physiol., 196:430-443.

MIYAMOTO, M. (2006). Effect of ramelteon (TAK-375), a selective $\mathrm{MT}_{1} / \mathrm{MT}_{2}$ receptor agonist, on motor performance in mice. Neurosci. Lett., 402(3):201-204.

MOLINERO, P., SOUTTO, M., BENOT, S., HMADCHA, A. \& GUERRERO J. M. (2000). Melatonin is responsible for the nocturnal increase observed in serum and thymus of thymosin alpha1 and thymulin concentrations: observations in rats and humans. J. Neuroimmunol., 103:180-188.

MONCADA, S., PALMER, R. M. \& HIGGS E. A. (1988). The discovery of nitric oxide as the endogenous nitrovasodilator. Hipertension, 12:365-372.

MONCADA, S., HIGGS, A. \& FURCHGOTT, R. (1997). International Union of Pharmacology Nomenclature in Nitric Oxide Research. Pharmacol. Rev., 49(2):137-142.

MORTANI-BARBOSA, E.J., FERREIRA, Z.S. \& MARKUS, R.P. (2000). Purinergic and noradrenergic cotransmission in the rat pineal gland. Eur. J. Pharmacol., 401:59-62.

MÜLLER-SCHEWEINITZER, E., GILLES, H., GRAPOW, M., KERN, T., REINEKE, D. \& ZEKOWSKI, H.R. (2004). Attenuation of lipopolysaccharide-induced 
hyperreactivity of human internal mammary arteries by melatonin. J. Pineal Res., 37: 92-97.

MUNDIGLER, A., DELlE-KARTH, G., KORENY, M., ZEHETGRUBER, M., STEINDL-MUNDA, P., MARKTL, W., FERTI, L. \& SIOSTRZONEK, P. (2002). Impaired circadian rhythm of melatonin secretion in sedated critically ill patients with severe sepsis. Crit. Care Med., 30:536-540.

NAJI, L., CARRILlO-VICO, A., GUERRERO, J.M. \& CALVO, J.R. (2004). Expression of membrane and nuclear melatonin receptors in mouse peripheral organs. Life Sci.,74(18):2227-2236.

NELSON, R.J \& DEMAS, G.E. (1996).Seasonal changes in immune function. Q. Ver. Biol., 71:511- 548 .

NOSJEAN, O., FERRO, M., COGE, F., BEAUVERGER, P. HENLIN, J.M., LEFOUlON, F., FAUCHERE，J.L., DELAGRANGE，P., CANET, E. \& BOUTIN, J.A. (2000). Identification of the melatonin binding site $M T_{3}$ as the quinone reductase 2. J Biol Chem., 275:1311-31317.

PALMER, R.M., FERRIGE, A.G. \& MONCADA, S. (1987). Nitric oxide release accounts for the biological activity of endothelium-derived relaxing factor. Nature, 327: 524- 526.

PAN, L., FU, J.H., XUE, X.D., XU, W., ZHOU, P. \& WEI, B. (2009). Melatonin protects against oxidative damage in a neonatal rat model of bronchopulmonary dysplasia. World j. Pediatr., 5(3):216-221.

PAREDES, S. D., KORKMAZ, A., MANCHESTER, L. C., TAN, D. X. \& REITER, R. J. (2009). Phytomelatonin: a review. J. Exp. Bot., 60: 57-69. 
PIRES-LAPA, M.A.Vias de transdução envolvidas na síntese de melatonina por fagócitos do colostro humano. 2010. Dissertação (Mestrado em Ciências Fisiologia). Instituto de Biociências, USP, São Paulo, 2010.

POBER, J.S. \& SESSA, W.C. (2007). Evolving functions of endothelial cells in inflammation. Nat. Rev. Immunol., 7(10):803-815.

POEGGELER, B., BALZER, I., HARDELAND, R. \& LERCHL, A. (1991). Pineal hormone melatonin oscillates also in the dinoflagellate Gonyaulax polyedra. Naturwissenschaften, 78:268-269.

POGAN, L., BISSONNETTE, P., PARENT, L. \& SAUVÉ, R. (2002). The effects of melatonin on $\mathrm{Ca}(2+)$ homeostasis in endothelial cells. J. Pineal Res., 33(1):37-47.

POHLMAN, T.H., STANNESS, K.A., BEATTY, P.G., OCHS, H.D. \& HARLAN, J.M. (1986) An endothelial cell surface factor(s) induced in vitro by lipopolysaccharide, interleukin 1 , and tumor necrosis factor-alpha increases neutrophil adherence by a CDw18-dependent mechanism. J. Immunol., 136:45484553.

PONTES, G.N., CARDOSO, E.C., CARNEIRO-SAMPAIO, M.M. \& MARKUS, R.P. (2006). Injury switches melatonin production source from endocrine (pineal) to paracrine (phagocytes) - melatonin in human colostrum and colostrums phagocytes. J. Pineal Res., 41(2):136-141.

PONTES, G.N., CARDOSO, E.C., CARNEIRO-SAMPAIO, M.M. \& MARKUS, R.P. (2007). Pineal melatonin and the innate immune response: the TNF-alpha increase after cesarean section suppresses nocturnal melatonin production. J. Pineal Res., 43(4): 365-371. 
PRENDERGAST, B. J., HOTCHKISS, A.K., BILBO, S. D., KINSEY, S.G. \& NELSON, R. J. (2003). Photoperiodic adjustments in immune function protect Siberian hamsters from lethal endotoxemia. J. Biol. Rhythms,18:51-62.

PRIES, A. R., SECOMB, T. W. \& GAEHTGENS, P. (2000). The endothelial surface layer. Pflügers Archiv : Eur. J. Phys., 440:653-666.

PRIVRATSKY, J., NEWMAN, D.K \& NEWMAN, P.J. (2010). PECAM-1: Conflicts of interest in inflammation. Life Sciences. 87:69-82.

RAHMAN, A. \& FAZAL, F. (2009). Hug tightly and say goodbye: role of endothelial ICAM-1 in leukocyte transmigration. Antioxid Redox Signal. 11(4):823-839.

RAM, P.T., DAI, J., YUAN, L., DONG, C., KIEFER, T.L., LAI, L. \& HILL, S.M. (2002). Involvement of the mt1 melatonin receptor in human breast cancer. Cancer Lett., 179(2):141-150.

REITER, R. J., TAN, D. X., MANCHESTER, L. C., SIMOPOUlOS, A. P., MALDONADO, M. D., FLORES, L. J., \& TERRON, M. P. (2007). Melatonin in edible plants (phytomelatonin): Identification, concentrations, bioavailability and proposed functions. World Rev. Nut. Diet, 97:211-230.

REPPERT, S.M., WEAVER, D.R. \& EBISAWA, T. (1994). Cloning and characterization of mammalian melatonin receptor that mediates reproductive and circadian responses. Neuron., 13(5):1177-1185.

REPPERT, S.M., GODSON, C., MAHLE, C.D., WEAVER, D.R., SLAUGENHAUPT, S.A. \& GUSELLA, J.F. (1995). Molecular characterization of a second melatonin receptor expressed in human retina and brain: The $\mathrm{Mel}_{1 \mathrm{~b}}$ melatonin receptor. Proc. Natl. Acad. Sci., 92:8734-8738.

RICHTER, H.G., TORRES-FARFAN, C., GARCIA-SESNICH, J., ABARZUACATAlAN, L., HENRIQUEZ, M.G., ALVAREZ-FELMER, M., GAETE, F., 
REHREN, G.E. \& SERON-FERRE, M. (2008). Rhythmic expression of functional MT1 melatonin receptors in the rat adrenal gland. Endocrinology, 149(3):995-1003.

RIEF, W., MILlS, P.J., ANCOLI-ISRAEL, S., ZIEGLER, M.G., PUNG M.A. \& DIMSDALE, J.E. Overnight changes of immune parameters and catecholamines are associated with mood and stress. Psychosom. Med., 72(8):755-62.

ROSEBOOM, P.H., COON, S.L., BALER, R., McCUNE, S.K., WELLER, J.L. \& KLEIN, D.C. (1996). Melatonin synthesis: analysis of the more than 150-fold nocturnal increase in serotonin $\mathrm{N}$-acetyltransferase messenger ribonucleic acid in the rat pineal gland. Endocrinol. 137:3033-3045.

ROTHWARF, D.M. \& KARIN, M. (1999). The NF-kB activation pathway: a paradigm in information transfer from membrane to nucleus. Sci. STKE., 1999(5).

SALLUSTO, F., LANZAVECCHIA, A. \& AHMED, R. (2010). From vaccines to memory and back. Immunity, 33(4):451-463.

SASAKI, M., JORDAN, P., JOH, T., ITOH, M., JENKINS, M., PAVLICK, K., MINAGAR, A. \& ALEXANDER, S.J. (2002). Melatonin reduces TNF-a induced expression of MAdCAM-1 via inhibition of NF-kappaB. BMC. Gastroenterol., 24:2-9.

SCHOMERUS, C., KORF, H.W., LAEDTKE, E., WELLER, J.L. \& KLEIN, D.C. (2000). Selective adrenergic/cyclic amp-dependent switch-off of proteasomal proteolysis alone switches on neural signal transduction: an example from the pineal gland. J Neurochem, 75:2123-2132.

SHARMA, R., OTTENHOF, T., RZECZKOWSKA, P.A. \& NILES, L.P. (2008). Epigenetic targets for melatonin: induction of histone H3 hyperacetylation and gene expression in C17.2 neural stem cells. J. Pineal Res., 45(3):277-284. 
SHIDA, C.S., CASTRUCCI, A.M. \& LAMY-FREUND, M.T. (1994). High melatonin solubility in aqueous medium. J. Pineal Res., 16(4): 198-201.

SILVA, S.O., RODRIGUES, M.R., XIMENES, V.F., BUENO-DA-SILVA, A.E., AMARANTE-MENDES, G.P. \& CAMPA, A. (2004). Neutrophils as a specific target for melatonin and kynuramines: effects on cytokine release. $J$. Neuroimmunol., 156(1-2):146-152.

SILVA, C.L.M., TAMURA, E.K., MACEDO, S.M.D., CECON, E., BUENO-ALVES, L., FARSKY, S.H.P., FERREIRA, Z.S. \& MARKUS, R.P. (2007). Melatonin inhibits nitric oxide production by microvascular endothelial cells in vivo and in vitro. Brit. J. Pharmacol., 151:195 - 205.

SIMONNEAUX, V. \& RIBELAYGA, C. (2003). Generation of the melatonin endocrine message in mammals: a review of the complex regulation of melatonin synthesis by norepinephrine, peptides, and other pineal transmitters. Pharmacol. Rev., 55:325-395.

SIVAKUMAR, V., LU, J., LING, E.A. \& KAUR, C. (2008). Vascular endothelial growth factor and nitric oxide production in response to hypoxia in the choroid plexus in neonatal brain. Brain Pathol., 18(1):71-85.

SKWARLO-SONTA, K., MAJEWSKI, P., MARKOWSKA, M., OBLAP, R. \& OLSZANSKA, B. (2003). Bidirectional communication between the pineal gland and the immune system. Can. J. Physiol, Pharmacol., 81(4):342-349.

SLUNGAARD, A. \& MAHONEY, J. R. Jr. (1991). Bromide-dependent toxicity of eosinophil peroxidase for endothelium and isolated working rat hearts: a model for eosinophilic endocarditis. J. Exp. Med., 173:117-126.

SMITH C.W. (2008). J. Adhesion molecules and receptors. Allergy Clin. Immunol., 121(2): 375-379. 
SOYBIR, G., TOPUZLU, C., ODABAS, O., DOLAY, K., BILIR, A. \& KÖKSOY, F. (2003). The effects of melatonin on angiogenesis and wound healing. Surg. Today, 33(12):896-901.

SPRENGER, J., HARDELAND, R., FUHRBERG, B. \& HAN, S.-Z. (1999). Melatonin and other 5-methoxylated indoles in yeast: Presence in high concentrations and dependence on tryptophan availability. Cytol., 64:209-213.

TAMURA, E.K., SILVA, C.L.M. \& MARKUS, R.P. (2006). Melatonin inhibits endothelial nitric oxide production in vitro. J. Pineal Res., 41(3):267-274.

TAMURA, E.K, CECON, E., MONTEIRO, A.W, SILVA, C.L. \& MARKUS, R.P. (2009). Melatonin inhibits LPS-induced NO production in rat endothelial cells. $J$. Pineal Res., 46:268-274.

TAMURA, E.K, FERNANDES, P.A., MARÇOLA, M., CRUZ-MACHADO, S.S. \& MARKUS, R.P. (2010). Long-Lasting Priming of Endothelial Cells by Plasma Melatonin Levels. Plos One, 5:1- 7.

TAN, D.X, MANCHESTER, L.C., TERRON, M.P. FLORE, J. \& REITER, R.J. (2007). One molecule, many derivatives: A never-ending interaction of melatonin with reactive oxygen and nitrogen species? J. Pineal Res. 42:28-42.

TAN, D.X., MANCHESTER, L.C., REITER, R.J., QI, W.B., ZHANG, M., WEINTRAUB, S.T., CABRERA, J., SAINZ, R.M. \& MAYO, J.C. (1999). Identification of highly elevated levels of melatonin in bone marrow: its origin and significance. Biochim. Biophys. Acta., 1472:206-214.

TAN, D. X., HARDElAND, R., MANCHESTER, L. C., PAREDES, S. D., KORKMAZ, A., SAINZ, R. M., MAYO, J. C., FUENTES-BROTO, L. E REITER, R. J. (2010). The changing biological roles of melatonin during 
evolution: from an antioxidant to signals of darkness, sexual selection and fitness. Biol. Rev., 85:607-623.

TECLEMARIAM-MESBAH, R., TER HORST, G.J., POSTEMA, F., WORTEL, J. \& BUIJS, R.M. (1999) Anatomical demonstration of the suprachiasmatic nucleuspineal pathway. J. Comp. Neurol., 406:171-182.

TURNER, A.J., BARNES, K., SCHWEIZER, A. \& VALDENAIRE, O. 1998. Isoforms of endothelin-converting enzyme: Why and where? Trends Pharmacol. Sci., 19:483-486.

VILLANUEVA, C. \& GIULIVI, C. (2010). Subcellular and cellular locations of nitric oxide synthase isoforms as determinants of health and disease. Free Radic. Biol. Med., 49(3):307-316.

WANG, C.H., HSIEH, I.C., SU PANG, J.H., CHERNG, W.J., LIN, S.J., TUNG, T.H. \& MEI, H.F. (2011). Factors associated with purity, biological function, and activation potential of endothelial colony-forming cells. Am. J. Physiol. Regul. Integr. Comp. Physiol. 300(3):586-594.

WASSMER, S.C., MOXON, C.A., TAYLOR, T., GRAU, G.E., MOLYNEUX, M.E. \& CRAIG, A.G. (2011). Vascular endothelial cells cultured from patients with cerebral or uncomplicated malaria exhibit differential reactivity to TNF. Cell. Microbiol., 13(2):198-209.

WIECHMANN, A.F. \& SUMMERS, J.A. (2008). Circadian rhythms in the eye: the physiological significance of melatonin receptors in ocular tissues. Prog. Retin. Eye Res.,27(2):137-160.

WITTCHEN, E.S. (2009). Endothelial signaling in paracellular and transcellular leukocyte transmigration. Front. Biosci., 14:2522-2545. 
WOODFIN, A., VOISIN, M.B. \& NOURSHARGH, S. (2007). PECAM-1: A MultiFunctional Molecule in Inflammation and Vascular Biology. Arterioscler. Thromb.Vasc. Biol., 27:2514-2523.

WU, C.C., CHIAO, C.W., HSIAO, G., CHEN, A. \& YEN, M.H. (2001). Melatonin prevents endotoxin-induced circulatory failure in rats. J. Pineal Res., 30(3):147156.

WU, J.Y., TSOU, M.Y., CHEN, T.H., CHEN, S.J., TSAO, C.M. \& WU, C.C. (2008). Therapeutic effects of melatonin on peritonitis-induced septic shock with multiple organ dysfunction syndrome in rats. J. Pineal Res., 45(1):106-116.

WURTMAN, R.J., AXELROD, J., SEDVALL, G. \& MOORE, R.Y (1967). Photic and neural control of the 24-hour norepinephrine rhythm in the rat pineal gland. $J$ Pharmacol Exp Ther., 157:487-492.

YAN, M.S., MATOUK, C.C. \& MARSDEN, P.A. (2010). Epigenetics of the vascular endothelium. J. Appl. Physiol., 109(3):916-926.

YE, X., DING, J., ZHOU, X., CHEN, G. \& LIU, S.F. (2008). Divergent roles of endothelial NFKB in multiple organ injury and bacterial clearance in mouse models of sepsis. J. Exp.Med., 205(6):1303-1315.

ZARBOCK, A. \& LEY, K. (2009). Neutrophil Adhesion and Activation under Flow. Microcirculation, 16:31-42. 


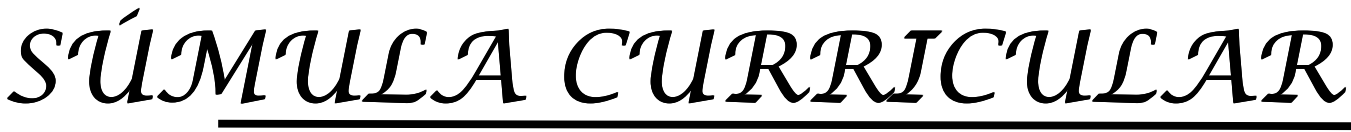




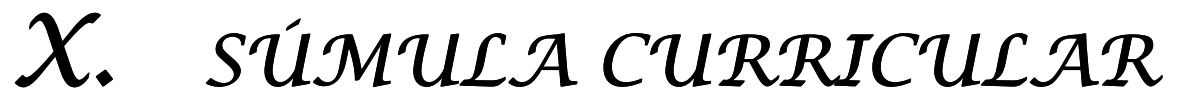

Nome: Marina Marçola Pereira de Freitas

Nascimento: 02/06/1987

Naturalidade: Uberlândia/MG - Brasil

Endereço eletrônico: marina.mpf@usp.br

\section{Formação Acadêmica/Titulação}

2009 - 2011 Mestrado em Fisiologia Geral.

Universidade de São Paulo, USP, São Paulo, Brasil

Título da dissertação: Efeito da melatonina sobre a reatividade de células endoteliais ex vivo.

Orientador: Regina Pekelmann Markus

Bolsista do(a): Fundação de Amparo à Pesquisa do Estado de São Paulo (FAPESP, processo no 2009/04000-0, vigência entre 01/09/2009 a 30/04/2011) ; Conselho Nacional de Desenvolvimento Científico e Tecnológico (CNPq, vigência entre 06/05/2009 a 31/08/2009).

2005 - 2008 Graduação em Ciências Biológicas Bacharelado e Licenciatura. Universidade Federal de Uberlândia, UFU, Uberlândia, Brasil Título: Comparação entre o efeito adjuvante de lectinas, $\mathrm{KM}+\mathrm{e}$ jacalina, e de oligodeoxinucleotídeos de $\mathrm{CpG}$ na imunização de camundongos C57BL/6 experimentalmente infectados por Toxoplasma gondii

Orientador: Prof. Dr. José Roberto Mineo

Bolsista do(a): Conselho Nacional de Desenvolvimento Científico e Tecnológico (CNPq, vigência entre Ago/2007 a Dez/2010). 


\title{
Atuação profissional
}

\author{
Universidade de São Paulo - USP
}

2009 - Atual Vínculo: Aluna Pós-Graduação

Regime: Dedicação Exclusiva

2011 - Atual Vínculo: Aluna Pós-Graduação, Enquadramento funcional: Programa de Preparação Pedagógica - Fisiologia para o Ensino Médio (PAE).

\section{Universidade Federal de Uberlândia - UFU}

2007 - 2008 Vínculo: Estudante de Graduação, Enquadramento funcional: Monitora de Disciplina - "Imunologia",

2006 - 2008 Vínculo: Estudante de Graduação, Enquadramento funcional: Aluna de Iniciação Científica, Projeto: "Efeito adjuvante das lectinas $\mathrm{KM}+\mathrm{e}$ jacalina na imunização de camundongos experimentalmente infectados por Toxoplasma gondii".

2006 - 2006 Vínculo: Estudante de Graduação, Enquadramento funcional: Monitora de disciplina - "Citologia e Histologia Geral"

\section{Prêmios}

2010

Menção honrosa de melhor pôster no $42^{\circ}$ Congresso Brasileiro de Farmacologia e Terapêutica Experimental, Sociedade Brasileira de Farmacologia e Terapêutica Experimental

\section{Artigos completos publicados em periódico}


MARKUS RP. (2010). Long-Lasting Priming of Endothelial Cells by Plasma Melatonin Levels. Plos One, v.5, p.e13958.

RIBEIRO DP, MARÇOLA M, CARDOSO MRD, PAJUABA ACAM, SILVA NM, MINEO TWP, SILVA JS, MINEO JR, SILVA DAO. (2009). CpG-ODN combined with Neospora caninum lysate, but not with excreted-secreted antigen, enhances protection against infection in mice. Vaccine (Guildford). , v.27, p.2570 - 2579, 2009.

\section{Trabalhos publicados em anais de eventos}

MARÇOLA M, PACHECO DR, SILVA DAO, OLIVEIRA TC, PAJUABA ACAM, MINEO JR. Efeito adjuvante dos dinucleotídeos de $\mathrm{CpG}$ na imunização de camundongos experimentalmente infectados por Toxoplasma gondii. In: VIII Encontro Interno e XII Seminário de Iniciação Científica da UFU, 2008, Uberlândia.

\section{Resumos publicados em anais de eventos internacionais}

TAMURA EK, MARÇOLA M, FERNANDES PACM, CRUZ-MACHADO, SS, MARKUS RP

Plasma melatonin primes for a long-term endothelial cell cultures In: 26th Conference of the I.S.C, 2010, Vigo, Espanha.

FERNANDES PACM, TAMURA EK, MARÇOLA M, CRUZ-MACHADO, SS, MARKUS RP. Melatonin as a player on the transition between the innate and acquire immune response In: 26th Conference of the I.S.C, 2010, Vigo, Espanha.

MARKUS RP, TAMURA EK, FERNANDES PACM, MARÇOLA M, MONTEIRO, AWA, CRUZ-MACHADO, SS. Endothelial cells (EC) cultures are preconditioned by environmental lighting melatonin (MEL) and lipopolysaccharide (LPS) treatment In: XI Congress of european biological rhythms society, 2009, Strasbourg, França.

MARÇOLA M, SILVA DAO, PACHECO DR, OLIVEIRA TC, BARREIRA MCRA, MINEO JR. 
Jacalin effect in immunization against Toxoplasma gondii infection. In: Toxoplasma Centennial Congress, Armação dos Búzios, Brasil, 2008.

\section{Resumos aceitos para apresentação eventos internacionais}

MARÇOLA M, TAMURA EK, FERNANDES PACM, CRUZ-MACHADO SS, MARKUS RP. Role of melatonin on priming and controlling endothelial cells reactivity during an acute inflammatory response. Submetido para FASEB SRC 2011, a realizarse de 26 de junho à 01 de julho de 2011.

\section{Resumos publicados em anais de eventos nacionais}

MARÇOLA, M, TAMURA EK, FERNANDES PACM, CRUZ-MACHADO, SS, MARKUS RP. Reactivity of endothelial cells in culture is conditioned by nocturnal melatonin surge in donor rats In: $42^{\circ}$ Congresso Brasileiro de Farmacologia e Terapêutica Experimental, 2010, Ribeirão Preto.

MARÇOLA M, TAMURA EK, FERNANDES PACM, CRUZ-MACHADO, SS, MONTEIRO, A.W.A, MARKUS RP. Endothelial cells (EC) from lipopolysaccharide (LPS) treated rats maintain a high expression of adhesion molecules and inducible nitric oxide synthase (iNOS) in culture In: XV Meeting of the Brazilian Society for Cell Biology, 2010, Ribeirão Preto.

MARÇOLA M, TAMURA EK, FERNANDES PACM, MONTEIRO, AWA, MARKUS RP. Reactivity of cultured endothelial cells are influenced by the endogenous rhythmicity of animal donor In: $41^{\circ}$ Congresso Brasileiro de Farmacologia e Terapêutica Experimental, 2009, Ribeirão Preto.

TAMURA EK, MARÇOLA M, FERNANDES PACM, MONTEIRO AWA, CRUZMACHADO

SS, MARKUS RP. Melatonin inhibits preconditioning of cultured endothelial cells induced by lipopolysaccharide (LPS). In: $41^{\circ}$ Congresso Brasileiro de Farmacologia e Terapêutica Experimental, Ribeirão Preto, Brasil, 2009. 
MARÇOLA M, PACHECO DR, SILVA DAO, OLIVEIRA TC, PAJUABA ACAM, BARREIRA MCRA, MINEO JR. Jacalin does not induce a protective immunity against Toxoplasma gondii infection in a murine model. In: XXXIII Congress of the Brazilian Society of Immunology, Ribeirão Preto, Brasil, 2008.

PACHECO DR, MARÇOLA M, CARDOSO MRD, PAJUABA ACAM, SILVA NM, MINEO TWP, MINEO JR, SILVA DAO. Vaccination with excreted-secreted antign from Neospora caninum (NcESA) plus CpG-ODN increases mortality and cerebral infection in C57BL/6 mice after parasite challenge In. XXXIII Congress of the Brazilian Society of Immunology, Ribeirão Preto, Brasil, 2008.

\section{Produção Técnica}

MARÇOLA M, Cronobiologia: Como os relógios biológicos funcionam a seu favor?, 2010. (Extensão. Curso de curta duração ministrado).

MARÇOLA M, Sistema Neuroimunoendócrino, 2010. (Desenvolvimento de material didático ou instrucional).

MARÇOLA M, Sistema Neuroimunoendócrino, 2010. (Extensão, Curso de curta duração ministrado)

MARÇOLA M, LIMA K, VI Curso de Inverno - Tópicos em Fisiologia Comparativa Estudos de caso em cronobiologia, 2009. (Desenvolvimento de material didático ou instrucional)

MARÇOLA M, LIMA K, VI Curso de Inverno - Tópicos em Fisiologia Comparativa Estudos de caso em cronobiologia, 2009. (Extensão, Curso de curta duração ministrado)

MARÇOLA M, MINEO JR, Técnicas de imunodiagnóstico e estratégias de vacinação, 2008. (Extensão, Curso de curta duração ministrado) 
MARÇOLA M, MINEO JR, Bioimunologia, 2007. (Extensão, Curso de curta duração ministrado)

\section{Orientações e Supervisões}

Paloma Leão Sousa. Eixo Imune-Pineal: Melatonina noturna condiciona células endoteliais em cultura. 2010. Orientação de outra natureza (VII Curso de Inverno: Tópicos em Fisiologia) - Instituto de Biociências - Universidade de São Paulo

Cristiane Castilho Fernandes da Silva. Expressão de iNOS e moléculas de adesão em culturas de células endoteliais incubadas com melatonina. 2010. Orientação de outra natureza (VII Curso de Inverno: Tópicos em Fisiologia) - Instituto de Biociências Universidade de São Paulo

\section{Organização de evento}

MARÇOLA, M: VII Curso de Inverno: Tópicos em Fisiologia Comparativa, 2010.

MARÇOLA, M: XXI Semana Científica de Estudos Biológicos, 2007.

MARÇOLA, M: I Simpósio de Interdisciplinar de Neurociências do Triângulo Mineiro, 2005. 


\section{XI. $\mathcal{A N E X O S}$}

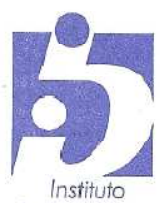

de Biociências

\section{$\frac{\text { UNIVERSIDADE DE SÃO PAULO }}{\text { INSTITUTO DE BIOCIÊNCIAS }}$}

OF.CEA/IB/012/2009

Ref. 2009.1.442.41.0

São Paulo, 03 de junho de 2009.

Prezada Senhora

Dirijo-me a V. Sa. para informar que a Comissão de Ética em Uso de Animais Vertebrados em Experimentação do IB, em reunião realizada no dia 02/06/2009, APROVOU a Projeto "Efeito da hora do dia de obtenção de células endoteliais na reatividade de culturas primárias" - Protocolo 089/2009, de sua responsabilidade (Colaboradores: Marina Marçola Pereira de Freitas, Eduardo Koji Tamura e outros).

\section{Atenciosamente.}

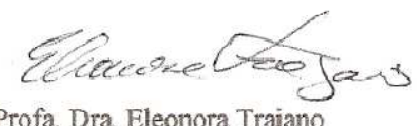

Profa. Dra. Eleonora Trajano

Coordenadora da Comissão de Ética em uso de Animais

Vertebrados em Experimentação do $\mathbb{I B}$

Ilma. Srá.

Profa. Dra. REGINA PEKELMANN MARKUS

Departamento de Fisiologia do IBUSP. 


\title{
Long-Lasting Priming of Endothelial Cells by Plasma Melatonin Levels
}

\section{Eduardo Koji Tamura, Pedro Augusto Fernandes, Marina Marçola, Sanseray da Silveira Cruz-Machado, Regina Pekelmann Markus*}

Laboratory of Chronopharmacology, Department of Physiology, Institute of Bioscience, Universidade de São Paulo, São Paulo, São Paulo, Brazil

\begin{abstract}
Background: Endothelial cells are of great interest for cell therapy and tissue engineering. Understanding the heterogeneity among cell lines originating from different sources and culture protocols may allow more standardized material to be obtained. In a recent paper, we showed that adrenalectomy interferes with the expression of membrane adhesion molecules on endothelial cells maintained in culture for 16 to 18 days. In addition, the pineal hormone, melatonin, reduces the adhesion of neutrophils to post-capillary veins in rats. Here, we evaluated whether the reactivity of cultured endothelial cells maintained for more than two weeks in culture is inversely correlated to plasma melatonin concentration.

Methodology/Principal Findings: The nocturnal levels of melatonin were manipulated by treating rats with LPS. Nocturnal plasma melatonin, significantly reduced two hours after LPS treatment, returned to control levels after six hours. Endothelial cells obtained from animals that had lower nocturnal melatonin levels significantly express enhanced adhesion molecules and iNOS, and have more leukocytes adhered than cells from animals that had normal nocturnal levels of melatonin (naive or injected with vehicle). Endothelial cells from animals sacrificed two hours after a simultaneous injection of LPS and melatonin present similar phenotype and function than those obtained from control animals. Analyzing together all the data, taking into account the plasma melatonin concentration versus the expression of adhesion molecules or iNOS we detected a significant inverse correlation.

Conclusions/Significance: Our data strongly suggest that the plasma melatonin level primes endothelial cells "in vivo," indicating that the state of the donor animal is translated to cells in culture and therefore, should be considered for establishing cell banks in ideal conditions.

Citation: Tamura EK, Fernandes PA, Marçola M, Cruz-Machado SdS, Markus RP (2010) Long Lasting Priming of Endothelial Cells by Plasma Melatonin Levels, PLoS ONE 5(11): e13958. doi:10.1371/journal.pone.0013958

Editor: Harald H. H. W. Schmidt, Maastricht University, Netherlands

Received March 16, 2010; Accepted October 19, 2010; Published November 12, 2010

Copyright: (c) 2010 Tamura et al. This is an open-access article distributed under the terms of the Creative Commons Attribution License, which permits unrestricted use, distribution, and reproduction in any medium, provided the original author and source are credited.

Funding: EKT and PACMF are post-doctoral fellows. MM and SSCM are graduate fellows of the Fundação de Amparo a Pesquisa do Estado de São Paulo (FAPESP). RPM is a senior fellow of the Conselho Nacional de Desenvolvimento Cientifico e Tecnológico (CNPq). This article was supported by grants from FAPESP (07/ 07871-6) and CNPq (472881/2009-4). The funders had no role in study design, data collection and analysis, decision to publish, or preparation of the manuscript.

Competing Interests: The authors have declared that no competing interests exist.

• E-mail: rpmarkus@usp.br
\end{abstract}

\section{Introduction}

Endothelial cells are located on the internal vascular laver and are responsible for modulating vascular tone and leukocyte migration. They are of great interest to cell therapy and tissue engineering. The heterogeneity among cells originated from different sources and culture protocols needs to be understood in order to obtain more standardized material to avoid rejection due to uncontrolled migration of immune competent cells [1].

Endothelial cells are known to be preconditioned "in vitro". Treatment with low concentrations of lipopolysaccharide LPS) or tumor necrosis factor (TNF) [2], and short periods of ischemiareperfusion $(\mathrm{I} / \mathrm{R})[3]$ protect the cells against subsequent harmful injuries. LPS activates the nuclear factor kappa B (NFKB) pathway, which leads to the expression of inducible nitric oxide synthase (iNOS) [4]. Melatonin, the indoleamine derived from serotonin and released at night by the pineal gland, inhibits LPSinduced iNOS expression [4] and leukocyte-endothelial interaction $[5,6]$. The short and long-term effects of melatonin are due to modulation of calcium metabolism [7], and inhibition of the NFKB pathway $[4]$, respectively.
During the last decades, many works showed the immune properties of melatonin, and more recently, we suggested the existence of an immune-pineal axis [8]. In such context, LPS and the inflammatory cytokine TNF, produced at the beginning of an inflammatory response, inhibits pineal gland nocturnal melatonin production $[9,10]$, which is restored by corticosterone [11]. Taking into account that melatonin inhibits the rolling and adhesion of leukocytes to endothelal cells [5], the reduction in plasma melatonin levels favors the migration of cells to the site of a lesion. A similar role is exerted by glucocorticoids, as adrenalectomy or inhibition of corticosterone synthesis also result in an increase in leukocyte rolling and adhesion to post-capillary veins [12].

Cultures of endothelial cells obtained from adrenalectomized rats adhere significantly more neutrophils than those obtained from sham operated or naive rats [13], indicating that these cells could be primed by "in vivo" conditions. Taking into account that a lack of adrenal glands is not a common condition, we looked for other models that could prime endothelial cells.

The present work aimed to evaluate whether plasma melatonin level could interfere in the reactivity of endothelial cells cultured up to 16-18 days. The pineal gland is an integral part of the innate 


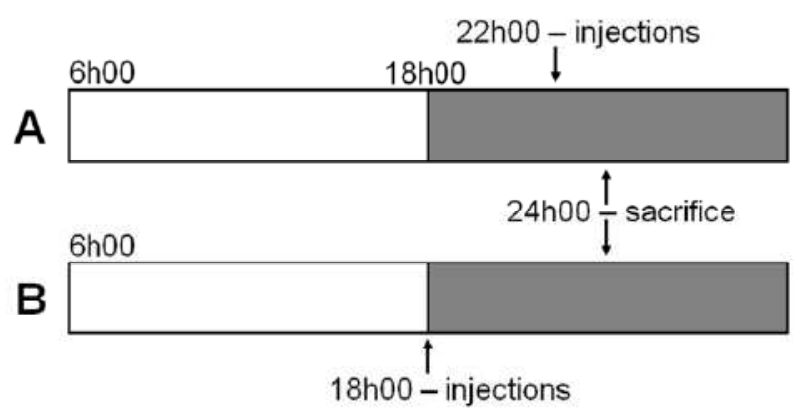

\begin{tabular}{l} 
Groups: \\
- Naïve \\
- Vehicle \\
- LPS $0.5 \mathrm{mg} / \mathrm{kg}$ \\
- LPS $0.5 \mathrm{mg} / \mathrm{kg}$ + MEL $3.0 \mathrm{mg} / \mathrm{kg}$ \\
\hline
\end{tabular}

Figure 1. Experimental protocols. Wistar rats were divided into four groups: naive, vehicle, lipopolysaccharide (LPS, $0.5 \mathrm{mg} / \mathrm{kg}$ ) and LPS + melatonin (MEL $3 \mathrm{mg} / \mathrm{kg}$ ). The intravenous (caudal vein) injections of vehicle, LPS or LPS + melatonin were performed two (A) or six (B) hours before sacrifice ( 6 hours after lights off $-24 h 00$ ). Grey portion represents the dark phase of the day.

doi:10.1371/journal.pone.0013958.g001

immune response, as the production of melatonin is suppressed in order to allow a full migration of neutrophils independently of the hour of the day [8]. Thus, we injected LPS in order to reduce nocturnal melatonin surge. As a negative control, rats were injected with LPS plus melatonin. We measured the adhesion of leukocytes to primed endothelial cells, as well as the expression of molecules related to endothelium activation, such as adhesion molecules and iNOS. The inverse correlation between plasma melatonin level and the reactivity of endothelial cells strongly suggest a priming of the cells by the status of the donor at the moment of death.

\section{Materials and Methods}

Adult Wistar rats $(300-330 \mathrm{~g})$, housed under $12 / 12 \mathrm{~h}$ light/ dark cycle (lights on at $06 \mathrm{~h} 00$ ), were divided into four groups: naïve, vehicle (saline $+5 \%$ ethanol), LPS $(0.5 \mathrm{mg} / \mathrm{kg}$, Sigma) and LPS + melatonin ( $3 \mathrm{mg} / \mathrm{kg}$, Sigma). All rats were killed six hours after lights off, which represent the maximal plasma melatonin concentration [11]. LPS injection (intravenous - caudal vein) was done two or six hours before decapitation (Fig. 1), in order to coincide with the TNF plasma peak (two hours) and with the return to basal levels (six hours) [14].

All experiments were carried out in compliance with ethical standards of our institution (Ethic Committee of the Institute of Bioscience of the University of São Paulo license 086/2008) and with the recommendations of the National Council on Experimental Animal Control (CONCEA).

\section{Melatonin assay}

Plasma melatonin was assayed using an ELISA kit with a detection limit of $3.0 \mathrm{pg} / \mathrm{mL}$ (GenWay Biotech Inc., CA, USA). The plates were read in a microplate spectrophotometer (SpectraMAX 250, Molecular Devices, CA, USA) at $405 \mathrm{~nm}$.

\section{Endothelial cell culture}

Primary cultures of endothelial cells were obtained from rat cremaster muscle according to the method described previously [15]. The cremaster was isolated, washed with phosphate saline solution (PSS; mM: $\mathrm{NaCl} 125.0, \mathrm{Na}_{2} \mathrm{HPO}_{4} 2.0, \mathrm{NaH}_{2} \mathrm{PO}_{4} 2.0$ and $\mathrm{KCl} 5.0$ ) and cut into pieces of approximately $2 \times 2 \mathrm{~mm}$. Two pieces per well were placed into a 24-well culture plate with Dulbecco's

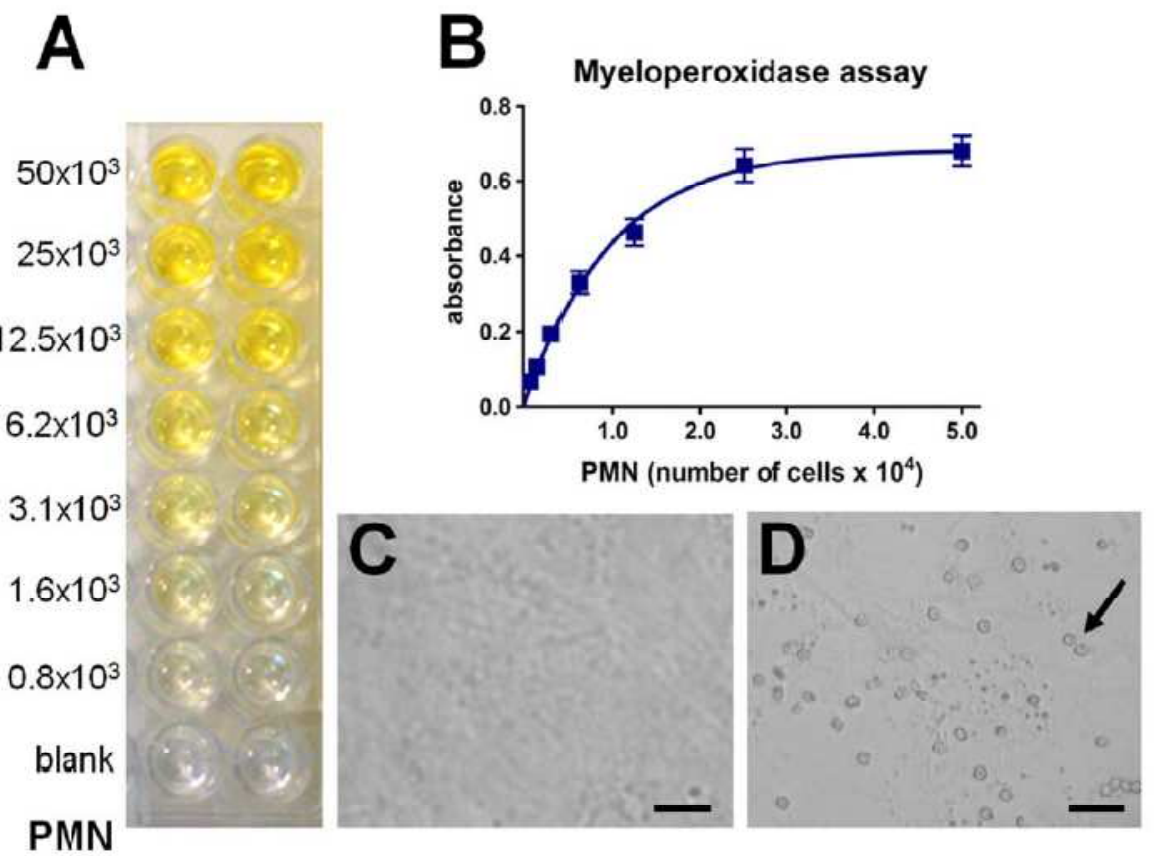

Figure 2. Standard curve of leukocyte adhesion assay. Representative image of experimental myeloperoxidase assay (A). The number of polymorphonuclear cells (PMN) was determined by comparison with standard curve (B). Confluent endcthelial cell culture adhered (D) or not (C) with leukocytes. Arrow indicates leukocytes adhered to endothelial cells. Scale bar $=50 \mu \mathrm{m}$. doi:10.1371/journal.pone.0013958.g002 


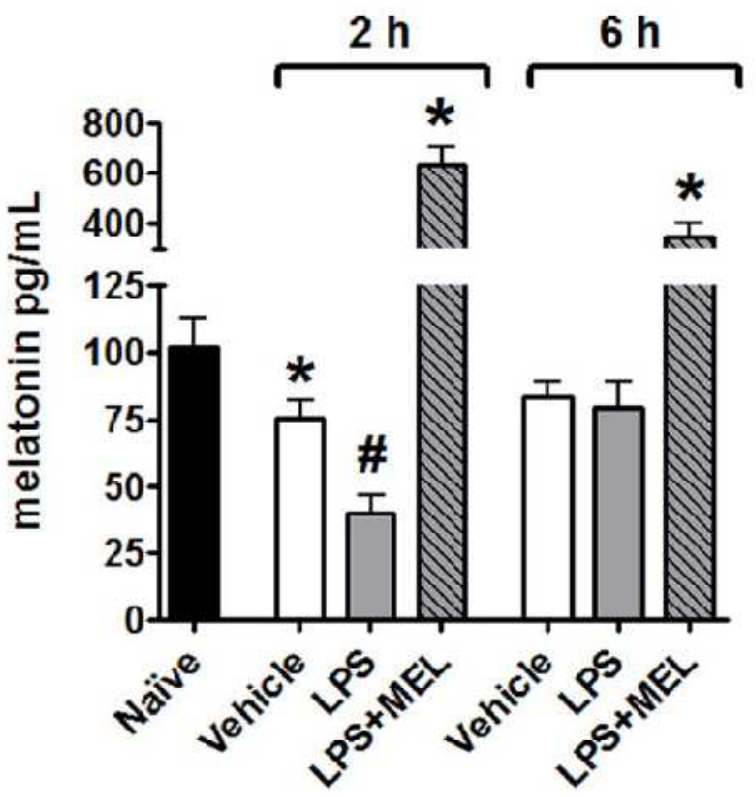

Figure 3. Nocturnal plasma melatonin levels vary during the development of response against lipopolysaccharide challenge. Plasma melatonin from naïve (black bar), vehicle injected (white bars), lipopolysaccharide injected (LPS, $0.5 \mathrm{mg} / \mathrm{kg}$; grey bars) or LPS plus melatonin injected ( $3 \mathrm{mg} / \mathrm{kg}$; grey diagonal striped bars) animals was determined by ELISA. The injections were performed 2 or 6 hours before sacrifice ( 6 hours after lights off -24 h 00). Data are expressed as mean \pm SEM, $n=48$ per group of at least two different experiments; ${ }^{*}$ signifi cantly different $(P<0.05)$ versus nä̈ve group (black bar); \# significantly different $(P<0.05)$ versus the 2 hours vehicle group (white bars). doi:10.1371/journal.pone. $0013958 . g 003$

Modified Eagle Medium (DMEM, Gibco) plus gentamicin ( $40 \mathrm{mg}$ / L, Gibco) and fetal bovine serum (20\%, Gibco). The explants were maintained in a humidified incubator $\left(37^{\circ} \mathrm{C}, 5 \% \mathrm{CO}_{2}\right)$. After $48 \mathrm{~h}$ the explants were removed, the cells were cultured till confluence (14-16 days), and the medium was changed every $48 \mathrm{~h}$.

\section{Immunofluorescence}

Protein detection by immunofluorescence was based on Tamura et al. [4]. Fndothelial cells were subcultured for $48 \mathrm{~h}$ in chamber slides ( 8 wells, $10^{4}$ cells/well), fixed in methanol/acetone (1:1, $15 \mathrm{~min},-20^{\circ} \mathrm{C}$ ) and incubated with antibodies for ICAM-1 or PECAM-1. (1:100) for 20 min (FITC-conjugated mouse anti-rat ICAM-1; intercellular adhesion molecule 1; PE-conjugated mouse anti-rat PECAM-1; platelet endothelial cell adhesion molecule 1; BD Pharmingen), or permeabilized for $30 \mathrm{~min}$ (room temperature) with Triton $\mathrm{X}-100(0.2 \%)$ and incubated overnight $\left(4^{\circ} \mathrm{C}\right)$ with iNOS antibody $1: 50$, TRITC-con ugated polyclonal rabbit anti-iNOS Santa Cruz Biotechnology). FITC and PE were excited at $488 \mathrm{~nm}$ (Argon laseri and $543 \mathrm{~nm}$ (HeNe laser) and emitted fluorescence was measured at $515-530$ and $560-575 \mathrm{~nm}$, respectively. TRITC was excited at $543 \mathrm{~nm}$ and emitted fluorescence at $514 \mathrm{~nm}$. Slides mounted in glycerol/PSS solution (1:1) were visualized by confocal micmscopy (T.SM 510; Carl 7eiss, Jena, Germany). Three fields with 4-6 cells were randomly chosen and imaged.

Leukocyte-endothelial cell adhesion assay

The adhesion assay was performed according to Lotufo et al. [6]. Endothelial oells $\left(10^{4}\right.$ cells/well) from difterent groups were

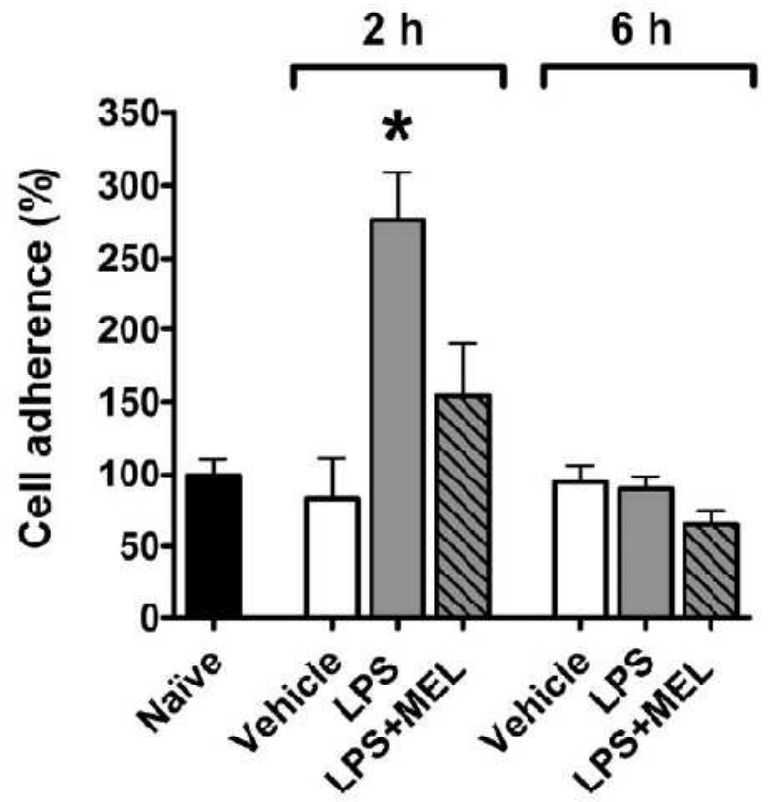

Figure 4. Melatonin regulates leukocyte adhesion to cultured endothelial cells. Leukocyte adhesion on endothelial cells cultures obtained from naïve (black bar), vehicle injected (white bars) lipopolysaccharide injected (LPS, $0.5 \mathrm{mg} / \mathrm{kg}$; grey bars) or LPS + melatonin injected (MEL $3.0 \mathrm{mg} / \mathrm{kg}$; grey diagonal striped bars) animals was determined by leukocyte-endothelial adhesion assay. The injections were performed 2 or 6 hours before sacrifice $i 6$ hours after lights off $-24 \mathrm{~h} 00$ ). Data are expressed as mean \pm SEM, $n=4-8$ per group of at least two different experiments; " significantly different $(P<0.05)$ versus 2 hours vehicle group (white bars).

doi:10.1371/journal.pone.0013958.g004

seeded in 96-well plates and allowed to grow till confluence, which was reached after 5 days.

For each experimental group, one well of endothelial cells was kept without polymorphonuclear cells (PMN). At the end of the experimental protocol we counted the number of endothelial cells in these wells, which was used to normalize the amount of PMN adhered. This procedure was important, hecause the amount of endothelial cells after reaching confluence could be different in each experimental group.

At the day of the experiment, endothelial cells, washed with Hank's balanced salt solution, were incubated for $30 \mathrm{~min}$ with PMN $5 \times 10^{4}$ cells/well) obtained from rat aorta blood. Nonadherent PMN were washed and myeloperoxidase colorimetric assay was applied to detect the PMN adhered to the endothelial cells layer, using tetrametylbenzidine (TMB; Sigma) as the peroxidase substrate. Cells were incubated at room temperature for $5 \mathrm{~min}$ with $0.25 \%$ of dodecyltrimethylammonium bromide as a peroxidase solubilizer and TMB $(5,3 \mu \mathrm{M})$ dissolved in sodium acetate buffer $(0.05 \mathrm{M}, \mathrm{pH} 5.8)$. In sequence, hydrogen peroxidase $(100 \mu \mathrm{I}, 9.5 \mathrm{mM})$ was incubated for exactly $? \mathrm{~min}$, and the reaction was stopped with sulfuric acid $(50 \mu \mathrm{L}, 1 \mathrm{M})$. The absorbance was determined using a microplate spectrophotometer (spectraM $\Lambda$ X 250, Molecular Devices, C $\Lambda, \mathrm{US} \Lambda$ ) at $420 \mathrm{~nm}$. The quantification of PMN adhesion was based on a standard curve obtained with known amounts of PMN. The number of adhered cells was calculated from the one-phase association equation obtained from the standard curve using Graphpad Prism Software (4.0; CA, USA) (lig. 2). 

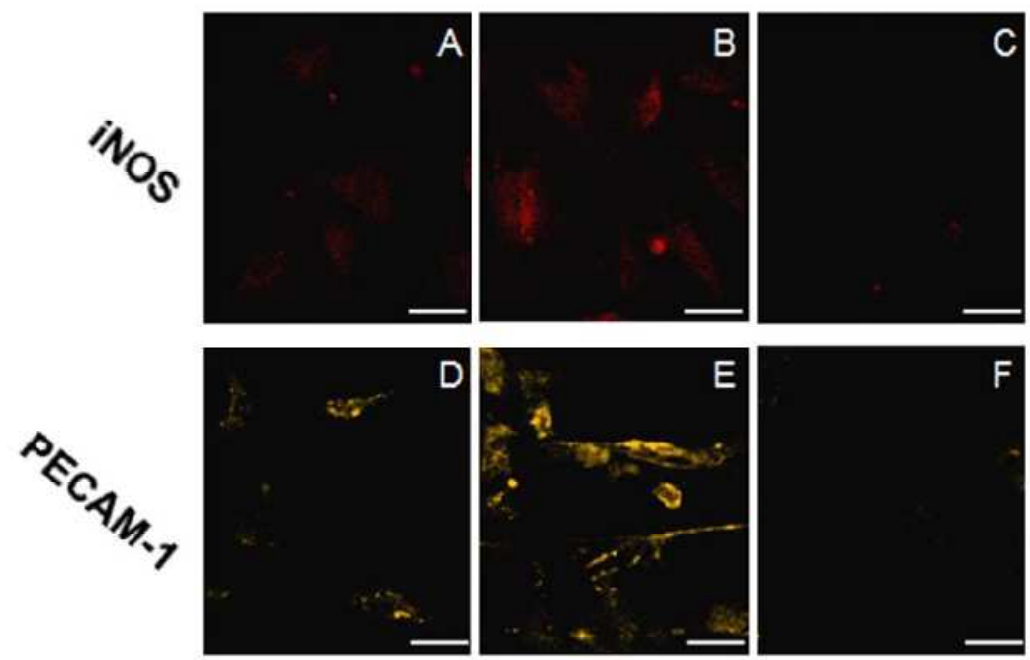

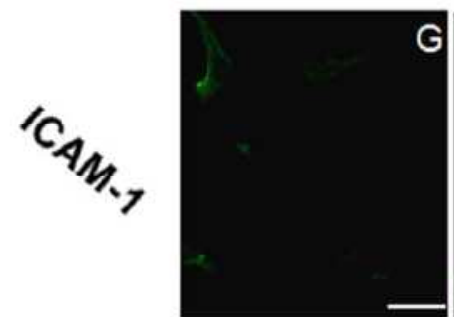

Vehicle

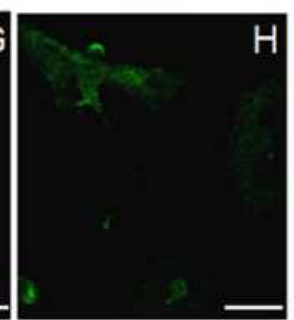

LPS

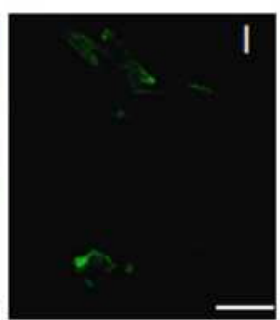

LPS + MEL

Figure 5. Melatonin regulates the lipopolysaccharide-induced iNOS, PECAM-1 and ICAM-1 expression in endothelial cells. Representative images of immunoflucrescence assays of iNOS (A-C), PECAM-1 (D-F) and ICAM-1 (G-l). Columns show cells obtained from vehicle (A, D and G), lipopolysaccharide (LPS) (B, E and H) and LPS + melatonin (MEL) (C, F and I) injected animals. Scale bar $=50 \mu \mathrm{m}$. doi:10.1371/journal.pone.0013958.g005

Statistical analysis

All the data are expressed as mean \pm S.E.M., and were compared by Student's t-test (two groups) or one-way ANOVA followed by Newman-Keuls test (more than two groups). Linear regression was tested by Analysis of Variance for detecting slopes (cxpressed as mean \pm S.E.M.) different from zero, and correlation between two parameters was tested according to Pearson's coefficient. Results were considered significantly different when $\mathrm{P}<0.05$. Plasma melatonin is shown as $\mathrm{pg} / \mathrm{mL}$ and the other results as percentage of naive group, set as $100 \%$.

\section{Results}

Plasma melatonin

Plasma melatonin concentration was significantly reduced after two, but not after six hours of I.PS injection when compared to the vehicle (Fig. 3). A smaller, but significant, reduction in melatonin was also observed when the group injected with vehicle ( 2 hours) was compared to naive group. Here, there was no difference after six hours. The administration of $3 \mathrm{mg} / \mathrm{kg}$ of melatonin increased the plasma concentration of melatonin to values much higher than those determined at night.

\section{Leukocytes adhesion}

LPS injected two hours before sacrifice increased the adhesion of leukocytes to endothelial cells in comparison to naive and vehicle groups. Conversely, six hours after LPS, no difference between adherence in experimental and control groups were observed. No difference between naive and vehicle groups was observed. Melatonin treatment inhibited the effect of LPS in the group sacrificed two hours after treatment (Fig. 4).

\section{iNOS expression}

iNOS expression in endothelial cells from the LPS group injected two hours before sacrifice was increased in comparison to naive and vehicle groups. On the other hand, six hours after LPS, no difference was observed. Melatonin inhibited the effect of LPS in the group sacrificed two hours after treatment (Fig. 5 A, B, C; figure 6).

\section{PECAM-1 and ICAM-1 expression}

LPS administration two, but not six, hours before sacrifice induced an increase in PFCAM-1 (Fig. 5D, F and 7A) and TCAM-1 (Fig. 5G, H and 7B) expression when compared to control groups. Melatonin impaired LPS-induced increase in the expression of these adhesion molecules (Fig. 5F and 5I). As occurred for the adhesion of leukocytes and iNOS expression, no difference in PECAM-1 and ICAM-1 was observed six hours after LPS injection when compared to control groups (Figs. 7A and 7B, respectively).

Correlation between plasma melatonin and the expression of adhesion molecules and iNOS

The distribution of the data obtained by correlating the plasma concentration of melatonin versus the expression of adhesion molecules or iNOS, for each rat, followed linear regressions that were signiicantly different from zero when tested by analysis of 
iNOS

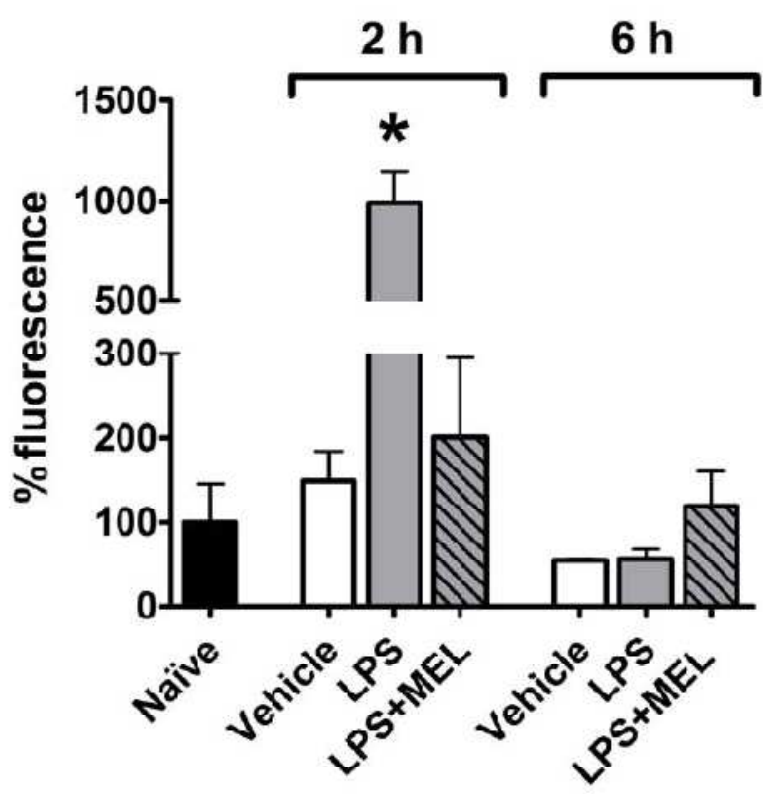

Figure 6. Melatonin regulates the lipopolysaccharide-induced iNOS expression in endothelial cells. iNOS expression in cultures obtained from naïve (black bar), vehicle injected (white bars) lipopolysaccharide injected (LPS, $0.5 \mathrm{mg} / \mathrm{kg}$; grey bars) or LPS + melatonin injected (MEL $3.0 \mathrm{mg} / \mathrm{kg}$; grey diagonal striped bars) animals was determined by confocal immunofluorescence. The injections were performed 2 or 6 hours before sacrifice ( 6 hours after lights off $-24 h 00$ ) Data are expressed as mean \pm SEM, $n=4-8$ per group; "significantly different $(P<0.05)$ versus 2 hours vehicle group (white bars'. doi:10.1371/journal.pone.0013958.g006

variance for lincar regression (Fig 8). The slopes of the lines for PECAM-1, ICAM-1 and iNOS were $-1.13 \pm 0.48,-1.25 \pm 0.44$ and $-0.91 \pm 0.22$, respectively. In addition, the Pearsen's coefficient also point to an inverse correlation between the plasma concentra- tion of melatonin and the expression of adhesion molecules (PECAM-1 and ICAM-1) or iNOS (Pearson's $r=-0.189$, -0.477 and -0.692 ; confidence limits -0.753 to $-0.146 ;-0.754$ to -0.057 and -0.869 to $-0.360 ; \mathrm{P}<0.009,0.029$ and 0.0007 ).

\section{Discussion}

The increasing interest in applying cell therapy needs to be preceded by improving the process of obtaining homogeneous and reliable cell cultures. Fndothelial cells, which form an interface between blood and vascular tissue, regulate vascular tonus and immune response. These cells can be obtained in a quiescent or activated state, depending on the health of the donor. In the activated state, cultured endothelial cells should have more leukocytes adhere to them than quiescent cells, and their use in vascular grafts or tissue engineering could be harmful for the recipient. We have previously shown that melatonin reduces rolling and adhesion of leukocytes to the post-capillary vein endothelial layer [5]. In the present paper, we evaluated whether melatonin could have a protective effect against LPS-induced priming of endothelial cells.

Here, for the first time, we demonstrate that endothelial cell cultures obtained from LPS-treated animals have a higher abilty to adhere leukocytes than cultures obtained from naive or vehicle treated animals. This effect is strictly related to the time-course of the innate immune response, as only cells derived from animals klled two, but not six, hours after LPS were in an activated state, since they exhibit a higher expression of achesion molecules and iNOS when compared to controls. It is interesting to note that the "in vitro" addition of IPS has a similar, hut slower time-course than that observed after "in vivo" priming. The incubation of human umbilical vein endothelial cells (HUVEC) with IPS leads to a maximal increase in leukocytes adhesion in four to six hours, and even after 24 hours the cells are still activated [16].

Melatonin concentration in the plasma of donor animals was reduced after two, but not six hours after LPS reatment, strongly suggesting its relevance in the priming of encothelial cells. The plasma TNF maximal peak in rats is supposed to occur two hours after LPS treatment, whle after six hours the level of TNF returns to basal values [14]. The time-course of plasma melatonin variation shown here reinforce a putative inhibition of pineal

\section{A}

PECAM-1

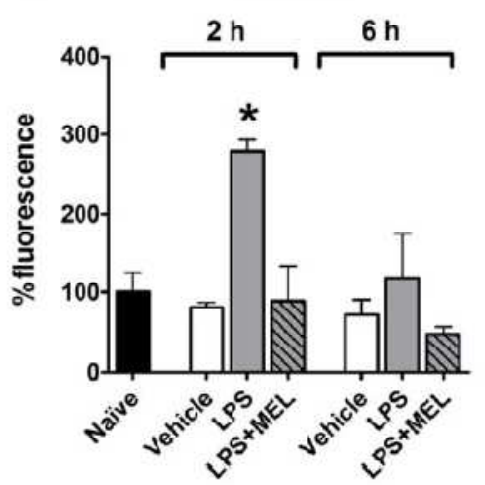

B

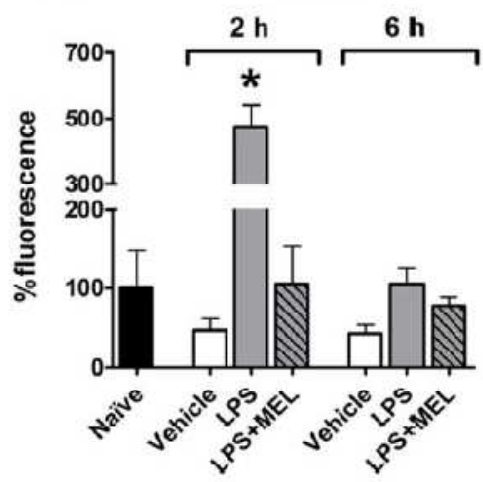

Figure 7. Melatonin regulates the lipopolysaccharide-induced PECAM-1 and ICAM-1 expression in endothelial cells. Expression of PECAM-1 (A) and ICAM-1 (B) in cultures obtained from naïve (black bar), vehicle injected (white bars), lipopolysaccharide injected (LPS, 0.5 mg/kg: grey bars) or LPS + melatonin injected (MEL $3.0 \mathrm{mg} / \mathrm{kg}$; grey diagonal striped bars) animals were determined by confocal immunofluorescence. The injections were performed 2 or 6 hours before sacrifice ( 6 hours after lights off -24 ho0). Data are expressed as mean $\pm S E M, n=4-8$ per group; * significantly different $(p<0.05)$ versus 2 hours vehicle group (white bars). doi:10.1371/journal.pone.0013958.9007 


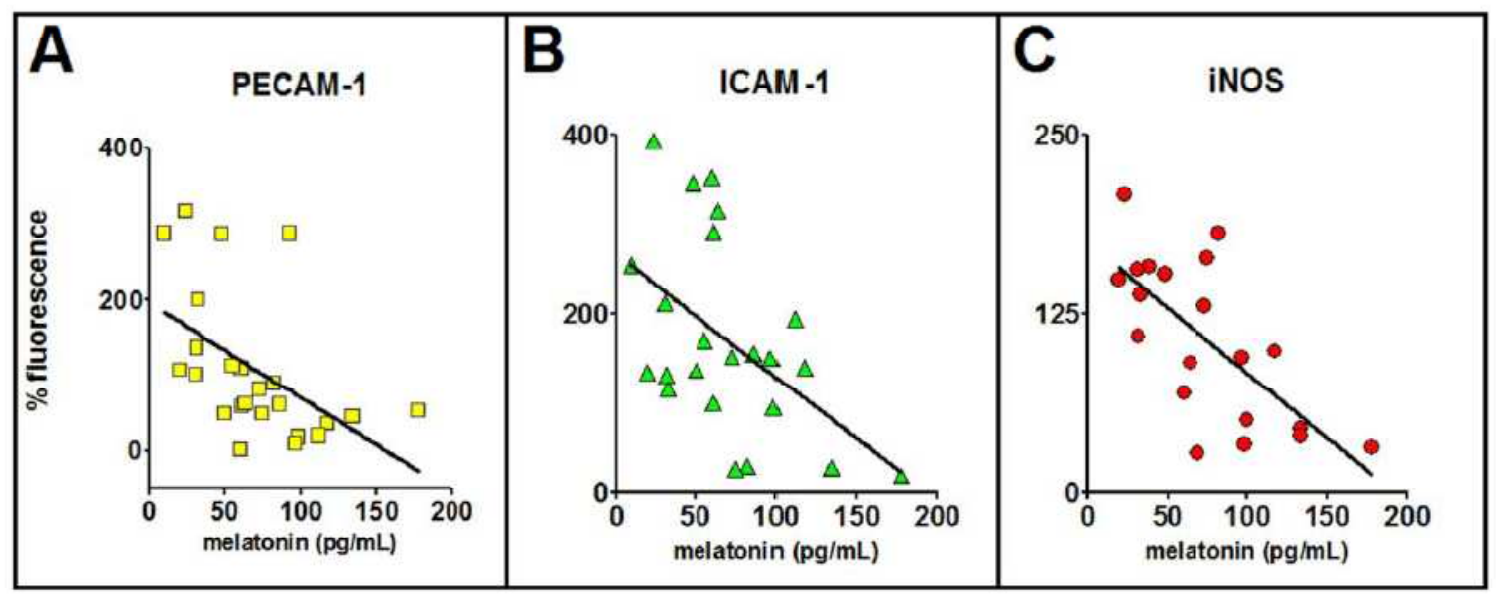

Figure 8. Plasma melatonin concentration is inversely correlated with the expression of adhesion molecules and iNOS in end othelial cells. The plasma concentration of melatonin ( $\mathrm{pg} / \mathrm{mL}$ ) in each rat was plotted against the expression of PECAM-1 (A), ICAM-1 (B) and iNOS (C) shown as the percentage of the fluorescence in the naïve group seeded in the same chamber slide. The values of the slopes and the Pearson's coefficient are shown in the text. doi:10.1371/journal.pone.0013958.g008

melatonin synthesis by TNF. We have recently shown that LPS inhibits nocturnal melatonin production by activating toll-like receptor 4 (TLR4) expressed in the pineal gland, and leading to a local production of TNF [9]. The activation of LPS and TNF receptors is transcribed by NFKB pathway [9]. This effect implies in the reduction in nocturnal melatonin surge. Activation of NFKB in the pineal gland inhibits the transcription of the key enzyme in melatonin synthesis, arylalkylamine- $N$-acetyltransferase $[10,17]$. Thus, LPS blocks nocturnal melatonin surge.

In order to confirm the role of melatonin in priming endothelial cells, we tested the response of cells obtained from animals treated with LPS plus melatonin. In this case, the state of the endothelial cells was similar to that of the control, suggesting that the reduction of melatonin by LPS was responsible for increasing endothelial cell activity. However, the concentration of melatonin attained in the plasma of animals injected with LPS plus melatonin was much higher than that observed in the vehicle group.

In order to verify whether plasma melatonin concentration is in fact the endogenous factor that translates LPS effect, we analyzed the correlation between plasma melatonin concentration and the expression of adhesion molecules and iNOS for each animal. These results clearly show a significant inverse correlation, strongly suggesting that melatonin primes endothelial cells regarding the expression of adhesion molecules and iNOS.

The mechanism of action of melatonin could be related to the inhibition of the NFKB pathway, which was shown in immune

\section{References}

1. Aird WC (2007) Phenotypic heterogeneity of the endothelium: I. Structure, function and mechanisms. Circ Res 100: 158-173.

2. Wada Y, Out $\mathrm{H}$, Wu S, Abid MR, Okada $\mathrm{H}$, et al, (2005) Preconditioning of primary human endothelial cells with inflammatory mediators alters the "set point" of the cell. FASEB J 19: 1914-1916.

3. Laude K, Beauchamp P, Thuillez C, Richard V (2002) Endothelial protective effects of preconditioning. Cardiovasc Res 15: 466-473.

4. Tamura EK, Cecon E, Monteiro AW, Silva CL, Markus RP (2009) Melatonin inhibits LPS-induced NO production in rat endothelial cells. J Pineal Res 46 268-279.

5. Lotufo CM, Lopes C, Dubocovich ML, Farsky SH, Markus RP (2001 Melatonin and $\mathrm{N}$-acetylserotonin inhibit leukocyte rolling and adhesion to rat microcirculation. Eur J Pharmacol 430: 351-357.

6. Lotufo CM, Yamashita CE, Farsky SH, Markus RP (2006) Melatonin effect on endothelial cells reduces vascular permeatility increase induced by leukotriene B4. Eur J Pharmacol 534: 258-263. competent cells [18], pineal gland [19] and in endothelial cells [4]. This pathway is known to result in epigenetic effects that could be inherited independently from changes in the genome [20], which would therefore, be maintained in long-term cultured cells.

In summary, this study evaluated the effect of melatonin in priming endothelial cells. The LPS-induced reduction in plasma melatonin levels is reflected in cultures that express higher amounts of adhesion molecules and iNOS, and have more leukocytes adhered than control cells. The restoration of plasma melatonin concentration six hours after LPS, or at the simultaneous injection of LPS and melatonin (in order to avoid the initial plasma reduction) leads to cultures with the same phenotype as the controls. Therefore, the state of the donor animal primes the cells and should be considered for establishing cell banks in ideal conditions.

\section{Acknowledgments}

The technical assistance of Alex Willian Arantes Monteiro and Debora Aparecida Moura is gratefully acknowledged.

\section{Author Contributions}

Conceived and designed the experiments: EKT PACMF RPM. Performed the experiments: EKT PACMF MM SdSCM. Analyzed the data: EKT PACMF MM RPM. Contributed reagents/materials/analysis tools: RPM. Wrote the paper: EKT PACMF MM SdSCM RPM.

7. Silva CI, Tamura EK, Maceds SM, Cecon E, Bueno-Alves L, et al. (2007) Melatonin inhibts nitric oxide production by microvascular endothelial cells in vivo and in vitro. $\mathrm{Br} J$ Pharmacl 151: 195-205.

8. Markus RP, Ferreira ZS, Fernandes PA, Cecon E (2007) The immune-pineal axis: a shuttle between endocrine and paracrine melatonin sources. Neuroimmuncmodulation 14: 126-133.

9. da Silveira Cruz-Machado S, Carvalho-Sousa CE, Tamura EK, Pinato L, Cecon E, et al. (2010) TLR4 and CD14 receptors expressed in rat pineal gland trigger NFKB pathway. J Pineal Res 49: 183-192.

10. Fernandes PACM, Cecon E, Markus RP, Ferreira 2S (2006) Effect of TNF-alpha on the melatonin synthetic pathway in the rat pineal gland: basis for a 'feedback' of the immune response on circartian timing. J Pineal Res 41 : $344-350$.

11. Fernandes PACM, Bothorel B, Clesse D, Monteiro AW, Calgari C, et al (2009) Local corticosterone infusion enhances nocturnal pineal melatonin production in vivo. J Neuroendocrinol 21: 90-97. 
12. Cavalcarti DM, Lotufo CM, Borelli P, Tavassi AM, Pereira AL (2006) Adrenal deficiency alters mechanisms of neutrophil mobilization. Mol Cell Endocrinol 249: $32-39$.

13. Gavalcanti DM, Lotuf, CM, Burtli P, Ferreira ZS, Markus RP, el al. (2007) Endogenous glucocorticoids control neutrophl mobilization from bone marrow to blood and tissues in non-inflammatory conditions. $\mathrm{Br} \mathrm{J}$ Pharmacol 152 $1291-1300$

14. Kakizaki Y, Watanobe H, Kohsaka A, Suda T (1999) Temporal profiles of interleukin- $1 \beta$, Interleukin- 6 , and tumor necrosis factor- $\alpha$ in the plasma and hypothahmic paraventricular nucleus after intravenous or intraperitonea administration of lipopolysaccharide in the rat: estimation by push-pul perfusion. Entocrine J 46: 487-496.

15. Tamura EK, Silva CL, Markus RP (2006) Melatonin inhibits endothelial nitric oxade in vitro. J Pineal Kes 41: 2b/-2/4.

16. Pohlman TH, Stanness KA, Beatty PG, Ochs HD, Harlan IM (1986) An endothetial cell surface factor(s) induced in vitro by lipopolysaccharide, interleukin 1, and tumor necrosis factor-alpha increases neutrophil adherence ty a CDwl8-riependent merhanism. J Immunol 136: 4548-4553

17. Ferreira ZS, Fernandes PA, Duma D, Assreay J. Avellar MC, et al. (2005 Corticosterone mofulates noradrenaine-induced melatonin synthesis through inhibition of mudear factor kappa B. I Pineal Res 38: 182-188.

18. Gilad E, Wong HR, Zingarelli B, Viràg L, O'Connor M, et al, (1998) Melatonin inhibits expression of the inducible isoform of nitric axide synthase in murine macrophages; role of inhibition of NFkappaB activation. FASEB J 12: 685-693.
mation

19. Cecon E, Femandes PA, Pinato L. Ferreira ZS, Markus RP (2010) Daily sariation of constitutively activated nuclear factor kappa B (NFKB) in rat pineal gland. Chronobiol Int 27: 52-67.

20. Bergte WV, Ndlovu MN, Hoya-Arias R, Disselblcem N, Gerlo S, et al. (2006) Keeping up NF-kB appearances: Epizenetic contrclo f imminity or inflammation triggered epigenetics. Biochem Pharmacol 72: 1114-1131. 